\title{
Large-Scale Integration of Meta-QTL and Genome-Wide Association Study Discovers the Genomic Regions and Candidate Genes for Yield and Yield-related Traits in Bread Wheat
}

\author{
Yang Yang \\ Northwest A\&amp;F University: Northwest Agriculture and Forestry University \\ Amo Aduragbemi \\ Northwest A\&amp;F University: Northwest Agriculture and Forestry University \\ Di Wei \\ Northwest A\&amp;F University: Northwest Agriculture and Forestry University \\ Yongmao Chai \\ Northwest A\&amp;F University: Northwest Agriculture and Forestry University \\ Jie Zheng \\ Northwest A\&amp;F University: Northwest Agriculture and Forestry University \\ Pengfang Qiao \\ Northwest A\&amp;F University: Northwest Agriculture and Forestry University \\ Chunge Cui \\ Northwest A\&amp;F University: Northwest Agriculture and Forestry University \\ Shan Lu \\ Northwest A\&amp;F University: Northwest Agriculture and Forestry University \\ Liang Chen \\ Northwest A\&amp;F University: Northwest Agriculture and Forestry University \\ Yin-Gang Hu ( $\sim$ huyingang@nwsuaf.edu.cn ) \\ Northwest A\&amp;F University https://orcid.org/0000-0002-1831-6375
}

\section{Research Article}

Keywords: Wheat, Yield and yield-related traits, Meta-QTL, GWAS, Homology comparison, TaKAO-4A

Posted Date: March 26th, 2021

DOI: https://doi.org/10.21203/rs.3.rs-342038/v1

License: (c) (i) This work is licensed under a Creative Commons Attribution 4.0 International License. Read Full License 


\section{Abstract}

Improving yield and yield-related traits are key goals in wheat breeding program. The integration of accumulated wheat genetic resources provides an opportunity to uncover important genomic regions and candidate genes that affect wheat yield. Here, a comprehensive Meta-QTL analysis was conducted on 2230 QTLs of yield-related traits obtained from 119 QTL studies. These QTLs were refined into 145 Meta-QTLs (MQTLs), and 89 MQTLs were verified by GWAS with different natural populations. The average confidence interval $(\mathrm{Cl})$ of these MQTLs was 2.92 times less than that of the initial QTLs. Furthermore, 76 core MQTL regions with a physical distance less than $25 \mathrm{Mb}$ were detected. Based on the homology analysis and expression patterns, 237 candidate genes in the MQTLs involved in photoperiod response, grain development, multiple plant growth regulator pathways, carbon and nitrogen metabolism, and spike and flower organ development were determined. A novel candidate gene TaKAO-4A was confirmed to be significantly associated with grain size, and a CAPS marker was developed based on its dominant haplotype. In summary, this study clarified a method based on the integration of Meta-QTL, GWAS and homology comparison to reveal the genomic regions and candidate genes that affect important yield-related traits in wheat. This work will help to lay a foundation for the identification, transfer and aggregation of these important QTLs or candidate genes in wheat high-yield breeding.

\section{Key Message}

Based on the large-scale integration of Meta-QTL and Genome-Wide Association Study, 76 high-confidence MQTL regions and 237 candidate genes that affected wheat yield and yield-related traits were discovered.

\section{Introduction}

Wheat is the most important food crops in the world besides to rice and maize, and is the largest crop in global trade volume (Borrill et al. 2015). It provides rich protein, dietary fiber and energy for human beings (Ling et al. 2013). Therefore, maintaining high and stable yield of wheat is essential to ensure global food security (Boyer and Westgate 2004). Global wheat production increased from 69.9 million tonnes in 2012 to 76.13 million tonnes with a growth rate of about $1 \%$ per year, which is far for achieving the goal of doubling the yield in 2050 (Ray et al. 2013, FAO 2020). Wheat yield is a complex quantitative trait, which is controlled by many low effect genes. Although wheat breeders have developed a large number of genetic and gene resources in the past few decades, due to the lack of integration of existing genetic resources related to yield-related traits, it is difficult to effectively transfer these genetic information into wheat breeding programs to improve wheat yield (Quraishi et al. 2017).

Wheat yield is affected by many factors, such as grain weight, tiller number, grain number per spike, harvest index, etc. Additionally, growth stages including heading stage, flowering stage and maturity stage are also closely related to the yield and environmental adaptability of wheat (Chen et al. 2012). Early mapping analysis of quantitative trait loci (QTL) based on biparental populations has accelerated the breeding process of improving wheat yield and other quantitative traits by marker assisted selection (MAS) (Gupta et al. 2020). However, QTL results based on bi-parental populations are heavily dependent on the genetic background of the population and environment, which greatly limits the wide adaptability and stability of these QTLs in wheat breeding programs (Khahani et al. 2020; Daware et al. 2017).

Meta-QTL analysis is an effective method to integrate QTL data and narrow QTL interval by integrating different QTLs in different trials to obtain reliable consistent and stable Meta-QTL (MQTL) (Welcker et al. 2011). The integrated MQTLs are not affected by the genetic background, population type and planting environment in the previous independent experiments, and can be directly used for quantitative trait improvement (Arcade et al. 2004; Sosnowski et al. 2012). This method has been widely used in plant genetic breeding, and has achieved good results in the QTL-integration of different quantitative traits in multiple crops, such as yield-related traits and combined insect resistance in maize (Wang et al. 2013; Wang et al. 2020b; Badji et al. 2018), drought tolerance and yield-related traits in rice (Khowaja et al. 2009; Raza et al. 2019; Khahani et al. 2020), agronomic and quality traits in cotton (Said et al. 2015). Similarly, meta-QTL studies of various traits in barley and wheat have also been reported, such as abiotic stress tolerance in barley (Zhang et al. 2017), root-related traits (Soriano and Alvaro 2019), drought resistance (Kumar et al. 2020), tan spot resistance (Liu et al. 2020), stem rust resistance (Yu et al. 2014), leaf rust resistance 
(Soriano and Royo 2015), pre-harvest sprouting resistance and Fusarium head blight resistance in wheat (Tai et al. 2021; Venske et al. 2019; Cai et al. 2019; Zheng et al. 2020), etc. In these wheat meta-QTL studies, the meta-QTL analysis of root-related traits, leaf rust resistance and stem rust resistance included the initial QTLs from both durum wheat and bread wheat. There were at least three Meta-QTL studies for yield and related traits in wheat, and multiple consistent MQTLs and candidate genes were found (Zhang et al. 2010; Quraishi et al. 2017; Liu et al. 2020). However, due to the relatively small number of QTL mapping studies (59, 27 and 24) and initial QTLs (541, 376 and 381), the results have certain limitations.

With the advent of DNA sequencing technology, high-throughput genotyping based on SNP array or Next-generation sequencing (NGS) provides convenience for genome-wide association studies (GWAS) of complex quantitative traits. This association analysis method based on natural population has been applied to QTL and gene mapping of rice, barley, wheat and other crops (Wang et al. 2015; Fan et al. 2016; Yang et al. 2020), and has also achieved very good results in QTL mapping for wheat yield and yield-related traits (Edae et al. 2014; Sun et al. 2017; Sukumaran et al. 2015). In addition, several important QTLs identified by GWAS have been further confirmed by linkage mapping studies (Chen et al. 2019; Wu et al. 2020). All of these indicate that the combination of Meta-QTL and GWAS can effectively integrate the original QTL results from different studies, so as to mine the key genomic regions and candidate genes that affect important quantitative traits. At the same time, the release of hexaploid wheat Chinese spring high-quality reference genome (International Wheat Genome Sequencing Consortium, 2018) provides an unprecedented opportunity to use these public resources to reveal the molecular mechanisms affecting important agronomic traits of wheat at the physical map level (Quraishi et al. 2017).

The objective of this study was to conduct a meta-QTL analysis of wheat yield-related QTLs published in recent years, and to further integrate the GWAS and transcriptome evidences to discover the genomic regions and important candidate genes that affect wheat yield. This work will help to better understand the genetic determinants of wheat yield and lay a foundation for the identification, transfer and aggregation of these important QTLs or candidate genes in wheat breeding.

\section{Materials And Methods}

\section{Scan of initial QTL for Meta-QTL analysis}

A detailed screening was carried out on recent published papers about yield QTL mapping studies in wheat (including bread wheat and durum wheat) from 1999 to 2020 , and a total of 119 studies were found that could provide the initial QTL information required for Meta-QTL analysis. The basic information of these studies was listed in Table S1, and some of them were also used in previous Meta-QTL analysis (Zhang et al. 2010; Quraishi et al. 2017; Liu et al. 2020). The initial QTLs were mainly associated with yield-related traits and growth stages. Of which, yield and yield-related traits mainly included the number of spikelets (sterile/fertile/total), the number of florets, the number of grain per spike, the weight of grain per spike, spike length, spike compactness, tiller number (single plant/unit area), yield (single plant/unit area), thousand grain weight, grain number (single plant/unit area), grain filling duration, grain filling rate, biomass and harvest coefficient, etc. The growth stages included heading date, flowering date and maturity date.

For each initial QTL, the necessary information was collected as: (1) associated trait; (2) type of QTL mapping population ( $F_{2}$, DH, RIL and Backcross); (3) size of population; (4) LOD value; (5) R² or PVE (phenotypic variance explained) value; (6) flanking or closely linked marker. To find more available initial QTLs, in most cases, the LOD threshold in the original study was followed, though some cases, it was less than 3. The QTLs that were significantly associated with traits but with $\mathrm{R}^{2}$ values less than $10 \%$ in individual studies, were also retained. For a very few QTLs that the LOD and $R^{2}$ values were missing in the previous studies, which was assumed as 3 and 10\%, respectively, following the common practice (Venske et al. 2019; Khahani et al. 2020). Additionally, the confidence intervals (Cl, 95\%) of each initial QTL was recalculated according to its population type and size, using the standard formula as following: (1) $\mathrm{F}_{2}$ and Backcross population, $\mathrm{Cl}=530$ /(Number of lines $\times \mathrm{R}^{2}$ ); (2) Recombinant Inbred Line (RIL) population, $\mathrm{Cl}=163 /\left(\right.$ Number of lines $\times \mathrm{R}^{2}$ ); (3) Double-haploid population, $\mathrm{Cl}=287 /\left(\right.$ Number of lines $\times \mathrm{R}^{2}$ ). Where Number of lines was the size of the mapping population used for QTL analysis, and $\mathrm{R}^{2}$ was the phenotype interpretation rate of QTL (Darvasi and Soller 1997; Guo et al. 2006). The details of these initial QTLs were listed in Table S2. 
Seven genetic maps containing multiple markers, which widely used in multiple QTL mapping studies, were used to construct a reference genetic map, including "Wheat, Consensus SSR, 2004", "Wheat, Composite, 2004" and "Wheat, Synthetic × Opata, BARC" downloaded from the GrainGenes website (https://wheat.pw.usda.gov/GG3/), "Wheat consensus map version 4.0" downloaded from its website (https://www.diversityarrays.com), and three SNP genetic maps derived from the 9K iSelect Beadchip Assay and iSelect 90K SNP Assay based on the Illumina platform, and genotyping by sequencing (GBS) (Venske et al. 2019; Cavanagh et al. 2013; Wang et al. 2014; Saintenac et al. 2013). R package LRmerge was used to construct the reference map for this Meta-QTL study with the optimized "synthetic" method, as it could produce genetic maps across multiple populations as described by Venske et al. (2019). The basic principle of this method is to collapse co-segregating markers into "bins" to ensure the ordering of most markers in the linkage maps is preserved. By deleting the smallest groups "bins" in the maps, it can effectively solve the position conflicts caused by the inconsistent order of markers in different maps.

96 independent genetic maps were extracted from the 119 independent QTL studies investigated, which derived from XX mapping populations including XX durum and XX bread wheat populations. Brief information of these genetic maps was listed in Table S3. BioMercator v4.2.3 delivers a graphical interface that allows the projection of single maps from different QTL studies onto a reference map (Sosnowski et al. 2012). All individual genetic maps (marker name, location) and related QTL statistics $\left(\mathrm{LOD}, \mathrm{R}^{2}, \mathrm{Cl}\right)$ and the reference map synthesized from 7 genetic maps were used as input files, through the iterative map compilation tool implemented in BioMercator v4.2.3, all single maps were integrated into the reference map and the consensus map was constructed.

\section{QTL projection and Meta-QTL analysis}

BioMercator first integrates independent genetic maps into a comprehensive map and secondly recalculates the marker position as well as those of the initial QTLs, based on a most likely consensus QTL distribution through meta-analysis algorithms. In this study, different methods were used to project the initial QTLs onto the consensus map, according to the sources of the initial QTLs. QTLs with individual genetic map information were projected based on the original map position as the input QTL file, while QTLs without genetic map information were projected based on their positions in the consensus map. As for the initial QTLs where genetic map information was missing or difficult to extract, QTLs were projected onto the consensus map according to the shared common markers. The following criteria were used to project the initial QTLs onto the consensus map: (1) If the peak marker of initial QTL was in the consensus map, the peak marker position were directly used; (2) If there were two flanking markers available, their middle position was used as the QTL peak position; (3) If there was only one flanking marker available, priority was given to a nearby marker instead, if no such marker found, only the flanking marker was used for QTL projection. The necessary information of these initial QTLs from different sources was input into the BioMercator software in different ways. QTLs with genetic map information were input in pairs with corresponding genetic maps, while QTLs without genetic map information were input in pairs with consensus map.

Secondly, Meta-QTL analysis was conducted following the standard process by BioMercator V4.2.3, as detailedly described by Arcade et al. (2004), Veyrieras et al. (2007) and Sosnowski et al. (2012). The best Meta-analysis model was screened by the multiple statistical methods added in the new version of BioMercator, such as AIC (Akaike information content), AICc (AIC correction), AIC3 (AIC 3 candidate models), BIC (Bayesian information criterion) and AWE (average weight of evidence), thus more than 4 Meta-QTLs can be supported in a single linkage map. The input files for Meta-QTL analysis with BioMercator V4.2.3 including the consensus genetic map and QTL information were placed as Table S2 and Table S3.

\section{Mapping of Meta-QTLs on the genome and verification by GWAS}

All obtained Meta-QTL (MQTL) were then mapped to the wheat reference genome. The markers on both sides of the MQTL confidence interval were manually searched, and their flanking or primer sequences were obtained from URGI Wheat (http://wheat-urgi.versailles.inra.fr), GrainGenes (https://wheat.pw.usda.gov/GG3/), DArT (https://www.diversityarrays.com) and Illumina company website (https://www.illumina.com). The obtained flanking sequences and primer sequences were blast aligned to the wheat Chinese Spring reference genome sequence to obtain the physical location information of these markers, 
based on the local BLASTN program. In addition, the physical locations of some SSR, SNP and DArT markers provided in the previous literatures were also used as reference (Cabral et al. 2018; Wang et al. 2014). For the markers, their physical locations were not found, the physical locations of the MQTL were anchored by manual screening.

The data on yield-related traits of 10 genome-wide association studies published from 2014 to 2020 were collected and used to verify the accuracy of these MQTL regions. The detailed information of these GWAS studies are listed in Table 2 . The phenotypic data of these studies were collected from 7 different countries, with population sizes ranging from 123 to 688 , including 3 spring wheat populations, 6 winter wheat populations and one mixed population of spring and winter wheat. Similar to anchoring the physical position of MQTL, the physical position of the MTA (Maker-Trait-Association) in these studies was obtained by BLASTN of the flanking sequence.

\section{Homology-based candidate gene mining and expression pattern analysis}

Considering the leading position of rice in gene function study, the strategy of wheat-rice orthologous comparison was used to mine the key candidate genes in the MQTL region. The basic information of all functionally verified yield-related genes published in rice was downloaded from the China Rice Data Center (https://www.ricedata.cn/), and their protein sequences were extracted using TBtools (Chen et al. 2020). Using the protein sequence of rice gene as the seed sequence, a BLASTP was conducted to all protein sequences of the wheat reference genome to find their orthologous genes in wheat. The genes located in the MQTL region were considered to be important candidate genes affecting wheat yield and yield-related traits.

Analyzing the expression patterns of orthologous genes between different species was an important way to determine their functional conservation (Tian et al. 2020). The transcriptomic data of multiple tissues in wheat deposited in the expression Visualization and Integration Platform (expVIP, http://www.wheat-expression.com) was downloaded to explore the tissue expression characteristics of candidate genes (Borrill et al. 2016), which including the expression data of 18 tissues during the whole growth period of wheat (Ramírez-González et al. 2018). The recently reported complete transcriptome data including endosperm, embryo and seed coat were used to analyze the expression patterns of candidate genes during grain development (Xiang et al. 2019). Expression levels of candidate genes were evaluated by transcripts per million (TPM) values, and displayed using the heat map of $\log _{2}(T P M+1)$. Additionally, STRING database (search tool for the retrival of interacting genes/proteins, https://string-db.org) were used to predict the protein-protein interaction (PPI).

\section{Plant materials}

To verify the contribution of candidate genes to yield and yield-related traits, 94 wheat accessions containing 3 foreign materials and 91 accessions from 3 major winter production regions in China were planted in field during three winter cropping seasons (October to early June of 2016-2017, 2017-2018 and 2018-2019)(Table S7), on the experimental farm of the Institute of Water Saving Agriculture in Arid Areas of China, Northwest A\&F University, Yangling, Shaanxi, China $\left(34^{\circ} 7^{\prime} \mathrm{N}, 108^{\circ} 4^{\prime} \mathrm{E}\right)$. The detailed field trials were as described in Yang et al. 2020.

\section{Yield-related traits measurement}

After harvest, the sun-dried grains were used for measuring thousand grain weight, grain yield per square meter, and the grain size traits including grain length and grain width were measured by image analysis provided with SC-E software (Hangzhou WanShen Detection Technology Co., Ltd., Hangzhou, China). All trait measurements were repeated at least 3 times.

\section{Dominant haplotype analysis and molecular marker development}

Based on the variations revealed by genotyping with the Affymetrix wheat 660K SNP array, the polymorphism SNP loci on the candidate genes were searched (Sun et al. 2020). The CAPS marker of TraesCS4A02G460100 was designed with the SNP primer design service on Triticeae Multi-omics Center (http://202.194.139.32) as Hha I-F/R (Hha I-F: TCTGAATGCAGGCTGACAAG; Hha IR: AAACAAGGAACGATGGCAAC). Genotyping of these wheat accessions was performed by one round of PCR and direct enzyme digestion of the PCR product. The PCR cycling conditions were as an initial denaturation of 2 min at $94{ }^{\circ} \mathrm{C}$, followed by 37 cycles of denaturation at $94^{\circ} \mathrm{C}$ for $30 \mathrm{~s}$, annealing at $60^{\circ} \mathrm{C}$ for $30 \mathrm{~s}$, extension at $72{ }^{\circ} \mathrm{C}$ for $10 \mathrm{~s}$, and a final extension at $72{ }^{\circ} \mathrm{C}$ for 25 
min. After three hours of digestion with Hha I enzyme, the products were separated on 2\% agarose gels, and DM2000 DNA marker (CoWin Biosciences Co., Ltd., Taizhou, China) was used to determine the fragment size.

\section{Results}

\section{Characteristics of yield-related QTL studies in wheat}

The characteristics of these 119 previous QTL studies were systematically analyzed (Table S1). These QTL studies based on biparental populations were mainly published on 2006 to 2015, while relatively few before 2005 and after 2015, which is closely related to the development of genotyping technology (Fig. 1a). Among the 130 mapping populations used in the 119 studies, 119 (91.54\%) were permanent populations, including 85 Recombinant inbred line (RIL) populations and 34 DH (doubled haploid) populations, respectively (Fig. 1b, Table S1), as these lines of the permanent mapping populations were genetically stable and could be used for phenotyping the yield and yield realted traits for years under different environment conditions.

A total of 2230 QTLs for yield and yield-related traits in wheat were found from the 130 populations of these independent studies, including 2027 QTLs (more than 80\%) directly related to yield related traits, and 203 QTLs for growth period related traits, which contribute to yield indirectly (Table S2). Many traits represent the same or similar trait but in different methods, such as 1000 grain weight, 50 grain weight and 200 grain weight for grain weight, while yield per plant, yield per square meter and yield per tiller for yield. After manual screening, these traits were mainly divided into 12 traits, including 9 yield-related traits (Grain weight, GW; Grain number, GN; Grain yield, GY; Tiller number, TN; Spike length, SL; Spikelet number, SLN; Grain-filling rate, GFR; Biomass, BY; Harvest index, $\mathrm{HI}$ ) and 3 traits of growth period (Days to maturity, DTM; Days to heading, DTH; Flowering date, FD) and some other traits (including spike compactness, threshing, etc.). The QTLs of GW, GN, TN and GY accounted for $63 \%$ of all the initial QTLs, which was closely related to their roles as important components of grain yield (Fig. 1c). Then, the QTLs of SL, SLN and GFR also accounted for a large proportion, as they were important factors in determining wheat grain yield. The distribution of QTLs on chromosomes was not even, with about 78.03\% (1740/2230) on A and B sub-genomes. Chromosome 5A, 2D and 7A contained 187, 165 and 136 QTLs respectively, accounting for $21.88 \%$ (488 / 2230) of the total, while chromosome 1D only found 38 QTLs (Fig. 1d, Table S2).

\section{Construction of a high-density consensus genetic map}

After combining the seven widely-used genetic maps with R package LRmerge, a reference genetic map including SSR, DArT, SNP and a few genes was obtained for downstream Meta-QTL analysis. Then, 96 individual genetic maps were projected onto the reference map, and finally a high-quality consensus map was constructed, which contained 572,862 markers with a total length of $4567.2 \mathrm{cM}$, and average length of each chromosome of $217.49 \mathrm{cM}$, which was consistent with that by Venske et al. (2019) (Fig. 2). These markers were unevenly distributed on chromosomes, and chromosome 2B contained the most 47,062 markers and constituted the longest linkage group of $316.13 \mathrm{cM}$. The marker density at the fore-end of chromosome was significantly higher than that at the end. This was mainly due to the independent genetic map used to construct the consensus map was composed of different numbers and types of markers, but overall, this was the best consensus map that could be built with a lot of marker information.

\section{Identification of Meta-QTLs of yield and yield-related traits}

Here, 2230 initial QTLs from 119 independent QTL studies were mapped to the consensus map (Fig. 1d). After Meta-QTL analysis, these initial QTLs were constituted into 145 MQTLs $(6.5 \%, 145 / 2230)$, and each MQTL contained at least two initial QTLs (Table 1). Of which, $96.55 \%$ (140/145) of MQTL were composed of three or more QTLs, and $44.83 \%$ (65/145) of MQTLs were composed of 11 to 50 QTLs (Fig. 3a). Six MQTLs contained more than 50 QTLs, including MQTL-5A-2 (52), MQTL-5A-3 (57), MQTL-2A-4 (60), MQTL-1B-3 (60), MQTL-4B-2 (69) and MQTL-2D-2 (82) (Table 1). These MQTLs composed of QTLs identified from different bi-parental populations were more reliable and stable for wheat yield improvement. All 145 MQTLs were distributed unevenly on different chromosomes. Chromosome 5B, 7B and 7D contained 9 MQTLs each, while only 4 MQTLs on chromosome 3D (Fig. 3b). The distribution of MQTL on chromosome was not consistent with that of initial QTL (Fig. 1d). To evaluate the reliability of MQTLs on different chromosomes, the average number of initial QTLs contained in MQTL on each 
chromosome was calculated (Fig. 3b). Although the number of MQTLs on chromosomes 2B, 2D and 5A was not high, they contained more QTLs from different populations, indicating that they may have more extensive adaptability in wheat yield improvement. The average confidence interval $(\mathrm{Cl}, 95 \%)$ of MQTL was 2.92 folds less than that of initial QTLs, and there were significant differences among different chromosomes (Fig. 3c). The average $\mathrm{Cl}$ of MQTL on chromosomes 4B and 5A decreased by 6.46 and 6.47 times, respectively, followed by 5.35 and 4.66 times on chromosomes 2D and $2 \mathrm{~A}$.

All MQTLs were associated with at least two different yield-related traits due to the multi-gene and multi-trait effects on yield formation (Table 1, Table S4). Among the 145 MQTLs, 130 MQTLs contained QTLs of GW, and 90 MQTLs contained three or more QTLs of GW. Similarly, 106 and 87 MQTLs contained QTLs of GN and TN, respectively. A total of 93 MQTLs were directly related to GY, with 84 MQTLs contained both QTLs of GY and GW, 74 MQTLs contained both QTLs of GY and GN, 63 MQTLs contained both QTLs of GY and TN, 69 MQTLs contained QTLs of GY, GN and GW, and 53 MQTLs contained QTLs of all four traits. In addition, 49, 50, 28 and 25 MQTLs of GY contained QTLs of SL, SLN, DTH and GFR, respectively.

\section{Verifying the MQTLs by previous GWAS studies}

To determine the reliability of Meta-QTL analysis, GWAS results on yield and yield-related traits published in recent years were used to verify the MQTLs (Table 2). Of the 145 MQTLs, 142 were mapped to the physical map of wheat reference genome, and 112 MQTLs were mapped into physical region less than $20 \mathrm{Mb}$, accounting for $77.24 \%$ of the total MQTLs (Table 1). Considering the relatively long linkage disequilibrium decay distance of wheat (about $5 \mathrm{Mb}$ ), the MTAs obtained from GWAS near MQTL in 5 Mb physical region were considered to be co-located with MQTLs. Eighty-nine of 142 MQTLs were verified in at least one GWAS research (Fig. 4). Among them, 75, 47 and 15 MQTLs were verified in GWAS with winter wheat, spring wheat populations and the mixed populations of spring wheat and winter wheat. In addition, 29 MQTLs were verified in both GWAS researches with spring wheat and winter wheat. Eleven MQTLs were detected at least 4 times in 10 GWAS researches, of them MQTL-1A-1 was detected 6 times, followed by MQTL-7A-1 with 5 times. It's worth noting that some MQTLs contained 30 or more initial QTLs were detected many times in the GWAS researches, such as MQTL-2B-1, MQTL-2D-2 and MQTL-5A-3. Furthermore, Multiple MQTL clusters or nested MQTLs were observed, such as MQTL-2D-1 (2D: 2.69-8.98 Mb) \& MQTL-2D-2 (2D: 5.44-10.32 Mb), and MQTL-2D-3 (2D: 24.98-28.76 Mb) \& MQTL-2D-4 (2D: 28.88-36.42 Mb). Finally, 76 core MQTLs verified in GWAS were screened out by excluding MQTLs with few QTLs (less than 3) and physical interval longer than 25 Mb (Fig. 5, Table 1). These core MQTLs had good collinearity between physical map and genetic map, and they were all clustered at both ends of the chromosomes, which were the gene intensive regions.

Some chromosome regions were identified in multiple studies to be associated with specific traits. As the key determinants of yield formation and their complex interrelationships, many MQTLs show influence on the three yield component traits of grain number, grain weight and tiller number, such as MQTL-1B-2, MQTL-1B-3, MQTL-3A-4, MQTL-3A-5, MQTL-5A-2, MQLT-5A-3 and MQTL-5A-7. In general, the MQTLs affecting the three traits of yield component were mainly concentrated in the terminal regions of chromosomes $1 B, 3 A$ and $5 A$. While the MQTLs affecting spike length and spikelet number were mainly concentrated in the terminal regions of chromosomes 1B, 2D, 4A and 5A, and the MQTLs affecting days to heading and flowering date were distributed on chromosomes 2B, 3B, 5A, 6B and 7A (Fig. 6).

\section{Homology-based candidate gene mining within MQTL regions}

Many cloned important genes related to wheat yield were found in MQTL regions, including two copies of TaPpd in MQTL-2A-5 and MQTL-2D-4 (Beales et al. 2007), TaVrn1 in MQTL-5A-3 (Yan et al. 2003), TaVrn2 in MQTL-5A-5 (Yan et al. 2004), TaVrn3 in MQTL-7B-2 (Yan et al. 2006), TaRht-B1(Rht1) in MQTL-4B-4 (Peng et al. 1999). All the MQTLs where these well-known genes located significantly affected the grain weight and grain number (Table 1). In addition to affecting grain weight and grain number, the three MQTLs including TaVrn1, TaVrn2 and TaVrn3 were also related to spikelet number, heading date and flowering date. TaRht1 was co-located with QTLs of grain weight, grain number and tiller number, finally contributed to wheat yield. In addition, multiple genes related to grain weight were found in the MQTL regions, such as TaGS-D1 in MQTL-7D-1 (Zhang et al. 2014), TaCKX2 in MQTL-3A-3 (Zhang et al. 2011), TaTGW6 in MQTL-3B-7 (Hanif et al. 2016), TaCWI in MQTL-4A-2 (Jiang et al. 2015), TaGS in MQTL-4A-8 (Bernard et al. 2008), TaCWI in MQTL-5B-7 (Jiang et al. 2015) and TaGS1a in MQTL-6A-4 (Guo et al. 
2013). Furthermore, some homologues of cloned yield-related genes were also found in the MQTLs, such as the A sub-genome copy of TaGS and TaNAM-B1 in MQTL-7A-1 and MQTL-6A-3, respectively.

To further explore the candidate genes affecting wheat yield and yield-related traits, a detailed search on the cloned genes in rice were conducted, and 398 functional genes affecting yield-related traits in rice were obtained (Table S5). Base on BLASTP, the orthologous wheat genes of these rice genes affecting yield were obtained. Among them, 237 genes were found in $115 \mathrm{MQTL}$ regions, with an average of 2 per MQTL (Table S6). The candidate genes in $97 \mathrm{MQTL}$ regions had similar effects on the yield and yield-related traits of both wheat and rice. For example, TraesCS1A02G045300 (MQTL-1A-3) and OsMKP1 affected GW, SLN and GN; TraesCS4A02G388400 (MQTL-4A-6) and OsFIE1 affected GW and GN, and TraesCS1A02G031200 (MQTL-1A-2) and its homologous gene affected TN (Table S6). It suggested that the functions of these candidate genes were relatively conserved in rice and wheat.

These genes have been reported to affect yield and yield-related traits in rice through a variety of pathways, such as regulating the content and sensitivity of multiple plant regulators, regulating photoperiod response, affecting photosynthesis, nitrogen use efficiency and flower organ formation. For example, OsGA20ox1, the orthologous of TraesCS4A02G319100 (MQTL-4A-2) and TraesCS5B02G560300 (MQTL-5B-7), affected GN and GW in rice by regulating gibberellin (GA) content (Wu et al. 2016). A MADSbox transcription factor gene OsMADS50, the orthologous of TraesCS4D02G341700 (MQTL-4D-5) and TraesCS5A02G515500 (MQTL-5A-7), regulated rice yield by affecting flowering time and tiller number (Ryu et al. 2010). A nitrate reductase gene OsNR2, the orthologous of TraesCS6A02G326200 (MQTL-6A-5) affected rice yield by regulating nitrate uptake and nitrogen use efficiency (Gao et al. 2019). In general, these candidate genes found were with high confidence, as the functions of their orthologous on affecting yield traits in rice have been investigated intensively (Table S5).

The expression characteristics of these candidate genes in several tissues during the critical stage of yield formation were further analyzed, and their expression patterns could be divided into two classes (Fig. 7, Fig. S1). Genes in Class I were mostly expressed in the stem and root tissues at the tillering stage, while genes in Class II were mainly expressed in the spike and spike organs. Genes in Class I mostly affected TN, such as TraesCS1A02G091300 (MQTL-1A-4), TraesCS5A02G516000 (MQTL-5A-7) and TraesCS5A02G000200 (MQTL-5A-1); while some of them were also highly expressed in flower organs and developing grains, and affected grain number and grain weight, such as TraesCS1B02G059100 (MQTL-1B-3), TraesCS5A02G000200 (MQTL-5A-1), etc. Most of the genes in Class II had effects on the spike traits of GN and SLN, such as TraesCS3A02G377600 (MQTL-3A-4), TraesCS5A02G511300 (MQTL-5A-7) and TraesCS1B02G069000 (MQTL-1B-3), and some of them were highly expressed in developing grains, which directly affect grain weight, such as TraesCS6A02G287300 (MQTL-6A-4) and TraesCS4A02G388400 (MQTL-4A-6) (Table S6, Fig. S1). Although most of these genes have multiple effects on yield-related traits, some representative candidate genes that have a greater impact on a few important yield-related traits were listed in Table 3 .

\section{A novel candidate gene affecting grain weight by regulating grain size}

The association analysis found that SNPs of a novel candidate gene encoding Cytochrome P450 (TraesCS4A02G460100) in MQTL-4A-8 contributed to yield and yield-related traits (Unpublished data). Therefore, a CAPS marker was designed on this A/G locus on its 3'UTR region. The $257 \mathrm{bp} \mathrm{PCR}$ product with the G allele could be cut into two fragments of 169 and 88 bp by Hha I, while the PCR product containing the A allele couldn't. Results showed that this CAPS marker could accurately distinguish this SNP alleles (A/G), and the PCR product and digested fragments were consistent with expectations (Fig. 8c). Therefore, two haplotypes, named Hap 1-A and Hap 2-G of TraesCS4A02G460100 among the wheat accessions could be revealed. The accessions with Hap 2-G had significantly higher grain width, grain length and thousand grain weight than these with Hap 1-A, especially for the grain width, which was extremely significant in all three environments (2016-2017, *ᄎ*; 2017-2018, **; 20182019, ***) (Fig. 8a, 8b).

Based on STRING service, the PPI (protein-protein interaction) analysis showed that TraesCS4A02G460100 interacted directly with 10 genes involved in GA synthesis including KOs, KO-likes and GA20oxs (Fig. 8d). These genes including KO-like-2B.1, KO$7 D, K O-7 A, G A 200 \times 2-3 B$ and TraesCS4A02G460100 were specifically and highly expressed in developing grain, and were grouped into one category (Fig. 8e). Further sequence alignment confirmed that TraesCS4A02G460100 (TaKAO-4A) was a copy of wheat $K A O$ genes on chromosome $4 \mathrm{~A}$, which encoded an ent-kaurenoic acid oxidase that catalyzed ent-Kaurene to produce GA

Page $8 / 42$ 
precursors $\mathrm{GA}_{12}$ on the upstream of the GA synthesis pathway (Pearce et al. 2015). To verify the role of TaKAO-4A in wheat grain development, the expression patterns of these genes involved in GA biosynthesis and signal transduction during grain development were further analyzed using a set of systematic transcriptome data during grain development (Xiang et al. 2019). The GA biosynthetic genes, such as TaKAO-4A, TaKO-7A and GA200x2-3B, were highly expressed in endosperm, while TaSYP-6A and TaGID2-3D, which involved in GA perception and signaling, were expressed in seed coat at higher levels (Fig. 8e). All of these suggested that TraesCS4A02G460100 (TaKAO-4A) played an important role in the GA biosynthesis to regulate grain size and thus affected grain weight. Interestingly, the TaGA200x1-4A was also found in our MQTL (MQTL-4A-2), and was regarded as one of the core candidate genes, which verified the reliability of our Meta-QTL, GWAS and homology alignment integration strategy in screening important candidate genes.

\section{Discussion}

\section{Characteristics of QTL and MQTL associated with wheat yield}

In recent 20 years, a large number of QTL mapping data for wheat yield and yield-related traits provided convenience for revealing the genetic basis of wheat yield formation (Quraishi et al. 2017). In this study, a total of 2027 QTLs related to yield and yield-related traits and 203 QTLs related to growth period from 119 independent studies were used for Meta-QTL analysis. Much more initial QTLs than previous studies were used for Meta-QTL analysis to ensure more comprehensive and accurate anchoring of genetic loci (Zhang et al. 2010; Quraishi et al. 2017; Liu et al. 2020). These initial QTLs were unevenly distributed on chromosomes, and more QTLs were found in A and B sub-genomes, which was consistent with previous studies (Zhang et al. 2010).

Meta-QTL analysis can eliminate the influence of genetic background, population type and planting environment on QTL, and effectively integrate QTL data in different backgrounds (Welcker et al. 2011). The number of initial QTLs used for Meta-QTL analysis was significantly and positively correlated with the accuracy of the statistical results. The more initial QTLs were used, the better the results of meta-analysis were (Quraishi et al. 2017). In this study, 44.83\% of MQTLs were composed of more than 11 initial QTLs, and 6 of them were composed of more than 50 QTLs, which was much higher than the previous studies (Zhang et al. 2010; Quraishi et al. 2017; Liu et al. 2020). The distribution of MQTL and initial QTL on different chromosomes was obviously inconsistent, which was mainly due to the different number of initial QTLs contained in MQTL. MQTLs containing initial QTLs identified from different bi-parental populations were more reliable and stable for wheat yield improvement.

Another advantage of Meta-QTL analysis is that it can effectively reduce the confidence interval (CI) of QTLs by aggregating QTL information from different genetic backgrounds, thus reducing the difficulty of transferring and aggregating important QTL regions in wheat breeding, and improving the accuracy of candidate gene prediction (Liu et al. 2020). The Cl of MQTL was 2.92 times narrower than that of initial QTL, better than 2.44 (12.7 cM / $5.2 \mathrm{cM}$ ) of Liu et al. (2020). Interestingly, the larger the number of initial QTLs contained in a MQTL, the greater the reduction of $\mathrm{Cl}$, which indicated that large-scale Meta-QTL analysis could effectively reduce the $\mathrm{Cl}$ of QTLs, especially when multiple QTLs from different studies were located at similar positions. There were 69 MQTLs for GY, GW and GN, and 52 MQTLs for GY, GW, GN and TN, which confirmed the significant effects of GW, GN and $T N$ on $G Y$, and indicated that there might be important candidate genes that could comprehensively improve yield by adjusting the three yield factors in these regions.

\section{Validation of MQTL in GWAS of different natural populations}

Compared with QTL mapping, genome-wide association study (GWAS) based on high-throughput sequencing or array technology is another high-precision method for identifying genomic regions of quantitative traits (Yang et al. 2020). Here, the GWAS results were used to verify the Meta-QTL results for the first time. More than $60 \%$ of MQTLs $(62.68 \%, 89 / 142)$ were colocated with MTAs from GWAS, which indicated that the impact of these genomic regions on yield may be less limited by genetic background. Furthermore, the contribution of wheat genomic regions to yield varied greatly with the environment. Therefore, breeding strategies vary according to the environment. There were 47 and 75 MQTLs verified by GWAS studies of spring wheat and winter wheat populations, respectively. These different MQTL regions may be more effective in improving yield for corresponding wheat regions, and can be used as an important target of wheat breeding in these different wheat planting areas.

Page $9 / 42$ 
MQTLs were mainly distributed in the gene rich regions of chromosomes, which was consistent with the study in Rice (Khahani et al. 2020). The identification of these MQTLs provided a basis for accurately mining candidate genes affecting yield (Veyreras et al. 2007).

\section{Candidate genes in MQTL and their roles in yield formation}

Several well-known important genes, including TaPpd (Beales et al. 2007), Tavrn 1 to Tavrn 3 (Yan et al. 2003, 2004, 2006), TaRht1 (Peng et al. 1999), TaGS (Bernard et al. 2008), etc., have been identified accurately in MQTLs. In addition to affecting grain weight and grain number, the three MQTLs including TaVrn1, TaVrn2 and TaVrn3 were also related to spikelet number, heading date and flowering date. This confirmed that these genes regulated the development of young spikes and grain filling by affecting the process of wheat heading and flowering, and finally affected the grain yield. Earlier study confirmed that materials containing TaRht1 showed an increase in grain number per spike and a decrease in thousand grain weight (Flintham et al. 1997). In this study, TaRht1 was found to be co-located with QTLs of grain weight, grain number and tiller number. Another dwarf gene, TaRht12, showed an increase in grain number per spike and effective tiller number, and a decrease in thousand grain weight (Chen et al. 2013). These two Rht genes affect the GA signal transduction and biosynthesis, respectively. Both the GA biosynthesis defective and GA signaling defective mutants show the phenotype of increased tillers, and the proper use of GA biosynthesis inhibitor Paclobutrazol (PAC) in wheat can increase tiller number (Lo et al. 2008, Silverstone et al. 1997, Assuero et al. 2012). All these confirmed that TaRht1 affects wheat yield components by regulating GA biosynthesis, thereby affecting wheat yield.

Considering the close evolutionary relationship between the genomes of Gramineae species (Gaut 2002), the analysis of homology relationship between wheat and model crop rice could broaden our understanding of genes in wheat. Meanwhile, the functional studies of a large number of genes in rice provided great convenience for the study of related crops including wheat (Yang et al. 2020). In addition, several important genes affecting rice yield have been confirmed to have similar functions in wheat, such as TaGS-D1, TaCKX2, TaTGW6, TaCWI, etc., which indicate that it is feasible to screen important candidate genes based on interspecific homology analysis (Zhang et al. 2014; Zhang et al. 2011; Hanif et al. 2016; Jiang et al. 2015). Here, 237 candidate genes homologous to yield-related genes in rice were found within the MQTL intervals, most of them affected the same traits in wheat and rice (Table S6). The functions of these genes were relatively conservative in rice and wheat, and could be used as primary gene resources for gene manipulation and directional improvement of wheat yield-related traits.

Some genes in rice have been proved to affect yield-related traits such as TN, GN and branch number per spike by regulating the sensitivity or content of plant growth regulators such as GA, IAA, brassinolide (BR) and cytokinin, thus affecting the final yield. Thirty five orthologous candidate genes of these genes in wheat were found in the MQTL regions determining the corresponding traits. For example, TraesCS4A02G319100 of MQTL-4A-2 (OsGA20ox1) (Wu et al. 2016) and TraesCS3D02G106100 of MQTL3D-3 (OsD2) (Liu et al. 2016) affected GN and GW by regulating IAA content, GA content and BR content, respectively. Some gene deletion mutants in rice showed decreased photosynthetic capacity and inhibited chlorophyll synthesis. The orthologues of these rice genes in wheat were also found in MQTLs, such as TraesCS4A02G388400 of MQTL-4A-6 (OsFIE1) (Cheng et al. 2019) and TraesCS4A02G010000 of MQTL-4A-1 (OsGUDK) (Ramegowda et al. 2014). Some candidate genes were found to regulate TN, GW, GN and other yield-related traits by regulating plant nitrogen transport and utilization, such as TraesCS6A02G326200 of MQTL-6A-5 (OsNR2) and TraesCS6D02G020700 of MQTL-6D-1 (OsNRT2) (Gao et al. 2019; Fan et al. 2016). The orthologous genes of $C K I$ and $H d 3 a$ were found in MQTL, which was proved to be related to the flowering and heading dates (Kwon et al. 2015; Galbiati et al. 2016). In addition, several orthologous genes related to grain size were also found in the MQTL region. A recent review showed that the genes affecting wheat yield were mainly concentrated in five aspects, including transcription factors that affect spike development, genes involved in signal transduction of growth regulators, genes involved in cell division and proliferation, flower regulators that affect the structure of inflorescence, and genes involved in carbohydrate metabolism (Nadolska-Orczyke et al. 2017). All five types of candidate genes were found in MQTLs, and their functions in rice have been confirmed.

Previous studies have shown that GA can directly regulate grain development (Tiwari et al. 2011). In this study, candidate genes involved in GA synthesis pathway including TaKAO-4A (TraesCS4A02G460100) and TaGA20ox1-4A (TraesCS4A02G319100) were found in the MQTL regions. A CAPS marker was developed on the TaKAO-4A gene, and its two haplotypes showed 
significant differences in grain width and grain weight in a three-year field trial of 94 wheat accessions. As an important upstream gene of GA synthesis, TaKAO-4A plays a key role in regulating GA content (Pearce et al. 2015). Additionally, the expression patterns of GA biosynthetic and signaling genes in separate tissues of the developing grain revealed that GA biosynthetic genes, such as TaKAO-4A, TaGA20ox2-3B and TaKO-7A, were mainly high-expressed in endosperm, while GA signaling gene TaGID2-3D was predominantly expressed in seed coat. TaGID2-3D, which encoded an important component GID2 of SCF ${ }^{\mathrm{GID}}$, was the key gene for the ubiquitination degradation of DALLA and the initiation of GA reaction. All of those indicated that the main synthesis site of GA in developing grains was in endosperm, while the signal transduction mainly occurs in outer layer, which implied the transportation of GA in inner and outer tissues of grains. Considering that this period is one of the rapid horizontal expansion stages of developing grain, it is obvious that bioactive GA may avoid limiting endosperm growth by promoting the cell expansion of seed coat. In addition, the Rht 1 dwarf mutant also exhibited reduced sensitivity to GA and reduced grain size (Flintham et al. 1997). TaGW2-6A, another important gene that affected grain size, had also been reported to regulate grain size through the GA synthesis pathway (Li et al. 2017). All these proved that GA content was important to regulate grain size. In general, the contribution of TaKAO-4A to grain size, especially grain width, was verified in natural populations, and a convenient and efficient CAPS marker was developed, which could be directly used in wheat molecular marker-assisted breeding.

Finally, based on their orthologues' functions in rice, expression patterns and existing knowledge of these candidate genes, a schematic diagram of the major candidate genes affected wheat yield formation were preliminarily drawn (Fig. 8). Similar to the summary of Nadolska-Orczyke et al. (2017), the candidate genes that play a role in photoperiod response, grain development, multiple plant growth regulator pathways, carbon and nitrogen metabolism, and spike and flower organ development were all found in the MQTL intervals. The results showed that photoperiod genes were mainly expressed in flower organs, affecting TN and grain filling by regulating multiple key growth stages; grain development genes were highly expressed in the process of grain development, affecting grain size, GN and grain filling; and the participation included GA, IAA, BR, JA and other growth regulator genes regulate plant development by regulating the response and sensitivity to different hormones, and have an impact on growth period, plant height, TN, GW, GN, etc.; while many genes affecting carbon and nitrogen metabolism are mainly expressed in the main sources such as roots, stems, leaves and other transport organs to regulate nitrogen absorption and utilization efficiency, so as to increase the inflow of source and then affect the yield. Finally, the genes on spike and flower organ formation were mainly expressed in spike development and floral organ, and affected the number of spikelets and grains by affecting the formation and fertility of spikelets. In general, based on homology alignment and expression pattern analysis, a large number of high confidence candidate genes affecting wheat yield were found in MQTL region.

\section{Declarations}

\section{Acknowledgement}

This research was supported by the National Natural Science Foundation of China (31671695 and 31501307) and the China 111 Project of the Ministry of Education of China (B12007).

\section{Author contributions}

Y.G.H. and L.C. designed the experiment, Y.Y. and A.A. performed the experiment and wrote the paper, D.W., Y.C. and J.Z. collected the previous studies, P.Q., C.C. and S.L. analyzed the data, Y.G.H. and L.C. reviewed the paper. All authors read and approved of the article.

\section{Compliance with ethical standards}

Conflict of interest All authors declare that they have no conflicts of interests.

Ethical standards We declare that these experiments complied with the ethical standards in China.

\section{References}


Ain Q, Rasheed A, Anwar A, Mahmood T, Imtiaz M, Mahmood T, Xia X, He Z, Quraishi UM (2015) Genome-wide association for grain yield under rainfed conditions in historical wheat cultivars from Pakistan. Front Plant Sci 6:743

Arcade A, Labourdette A, Falque M, Mangin B, Chardon F, Charcosset A, Joets J (2004) BioMercator: integrating genetic maps and QTL towards discovery of candidate genes. Bioinformatics 20:2324-2326

Assanga SO, Fuentealba M, Zhang G, Tan C, Dhakal S, Rudd JC Ibrahim AMH, Xue Q, Haley S, Chen J, Chao S, Baker J, Jessup K, Liu S (2017) Mapping of quantitative trait loci for grain yield and its components in a US popular winter wheat TAM 111 using 90K SNPs. Plos One 12:e0189669

Assuero SG, Lorenzo M, Pérez Ramírez N, Velázquez L, Tognetti JA (2012) Tillering promotion by paclobutrazol in wheat and its relationship with plant carbohydrate status. New Zealand Journal of Agricultural Research 55:347-358.

Badji A, Otim M, Machida L, Odong T, Kwemoi DB, Okii D, Agbahoungba S, Mwila N, Kumi F, Ibanda A, Mugo S, Kyamanywa S and Rubaihayo P (2018) Maize combined insect resistance genomic regions and their co-localization with cell wall constituents revealed by tissue-specific QTL meta-analyses. Front Plant Sci. 9:895

Beales J, Turner A, GriYths S, Snape JW, Laurie DA (2007) A Pseudo-Response Regulator is misexpressed in the photoperiod insensitive Ppd-D1a mutant of wheat (Triticum aestivum L.). Theor Appl Genet 115:721-733

Bednarek J, Boulaflous A, Girousse C, Ravel C, Tassy C, Barret P, Bouzidi MF, Mouzeyar S (2012) Down-regulation of the TaGW2 gene by RNA interference results in decreased grain size and weight in wheat. J Exp Bot 63:5945-5955

Bernard SM, Møller ALB, Dionisio G, Kichey T, Jahn TP, Dubois F, Baudo M, Lopes MS, Terce'-Laforgue T, Foyer CH, Parry MAJ, Forde BG, Araus JL, Hirel B, Schjoerring JK, Habash DZ (2008) Gene expression, cellular localisation and function of glutamine synthetase isozymes in wheat (Triticum aestivum L.). Plant Mol Biol 67:89-105

Borrill P, Adamski N, Uauy C (2015) Genomics as the key to unlocking the polyploid potential of wheat. New Phytol 208:10081022

Borrill P, Ramirez-Gonzalez R, Uauy C (2016) expVIP: a customizable RNA-seq data analysis and visualisation platform. Plant Physiol 170:2172-2186

Boyer JS, Westgate ME (2004) Grain yields with limited water. J Exp Bot 55:2385-2394

Cabral AL, Jordan MC, Larson G, Somers DJ, Gavin Humphreys D, McCartney CA (2018) Relationship between QTL for grain shape, grain weight, test weight, milling yield, and plant height in the spring wheat cross RL4452/'AC Domain'. Plos One 13:e0190681

Cai J, Wang S, Su Z, Li T, Zhang X, Bai G (2019) Meta-analysis of QTL for Fusarium head blight resistance in Chinese wheat landraces. Crop J 7:784-798

Cavanagh CR, Chao S, Wang S, Huang BE, Stephen S, Kiani S, Forrest k, Saintenac C, Brown-Guedira GL, Akhunova A, See D, Bai G, Pumphrey M, Tomar L, Wong D, Kong S, Reynolds M, Silva MLd, Bockelman H, Talbert L, Anderson JA, Dreisigacker S, Baenziger S, Carter A, Korzun V, Morrell PL, Dubcovsky J, Morell MK, Sorrells ME, Hayden MJ, Akhunov E (2013) Genome-wide comparative diversity uncovers multiple targets of selection for improvement in hexaploid wheat landraces and cultivars. Proc Natl Acad Sci USA 110:8057-8062

Chen C, Chen H, Zhang Y, Thomas HR, Frank MH, He Y, Xia R (2020) TBtools: an integrative toolkit developed for interactive analyses of big biological data. Mol Plant 13:1194-1202

Chen G, Zhang H, Deng Z, Wu R, Li D, Wang M, Tian J (2016) Genome-wide association study for kernel weight-related traits using SNPs in a Chinese winter wheat population. Euphytica 212:173-185

Page $12 / 42$ 
Chen J, Zhang F, Zhao C, Lv G, Sun C, Pan Y, Guo X, Chen F (2019) Genome-wide association study of six quality traits reveals the association of the TaRPP13L1 gene with flour colour in Chinese bread wheat. Plant Biotechnol J 17:2106-2122

Chen L, Andrew LP, Anthony GC, Martin AJP, Hu YG (2013) GA-responsive dwarfing gene Rht12 affects the developmental and agronomic traits in common bread wheat. Plos One 8:e62285

Chen X, Min D, Yasir TA, Hu YG (2012) Evaluation of 14 morphological, yield-related and physiological traits as indicators of drought tolerance in Chinese winter bread wheat revealed by analysis of the membership function value of drought tolerance (MFVD). Field Crop Res 137:195-201

Cheng X, Pan M, E Z, Zhou Y, Niu B, Chen C (2019) Functional divergence of two duplicated Fertilization Independent Endosperm genes in rice with respect to seed development. Plant J 104:124-137

Darvasi A, Soller M (1997) A simple method to calculate resolving power and confidence interval of QTL map location. Behav Genet 27:125-132

Daware AV, Srivastava R, Singh AK, Parida SK, Tyagi AK (2017) Regional association analysis of metaQTLs delineates candidate grain size genes in rice. Front Plant Sci 8:807

Edae EA, Byrne PF, Haley SD, Lopes MS, Reynolds MP (2014) Genome-wide association mapping of yield and yield components of spring wheat under contrasting moisture regimes. Theor Appl Genet 127:791-807

Fan Y, Zhou G, Shabala S, Chen Z-H, Cai S, Li C and Zhou M (2016) Genome-Wide Association Study reveals a new QTL for salinity tolerance in barley (Hordeum vulgare L.). Front Plant Sci 7:946

FAO (2020) Crop Prospects and Food Situation-Quarterly Global Report No. 4, Rome. https://doi.org/10.4060/cb2334en

Flintham JE, Börner A, Worland AJ, Gale MD (1997) Optimizing wheat grain yield: effects of Rht (gibberellin-insensitive) dwarfing genes. J Agr Sci 128:11-25

Galbiati F, Chiozzotto R, Locatelli F, Spada A, Genga A, Fornara F (2016) Hd3a, RFT1 and Ehd1 integrate photoperiodic and drought stress signals to delay the floral transition in rice. Plant Cell Environ 39:1982-1993

Gao ZY, Wang YF, Chen G, Zhang AP, Yang SL, Shang LG, Wang DY, Ruan BP, Liu CL, Jiang HZ, Dong GJ, Zhu L, Hu J, Zhang GH, Zeng DL, Guo LB, Xu GH, Teng S, Harberd NP, Qian Q (2019) The indica nitrate reductase gene OsNR2 allele enhances rice yield potential and nitrogen use efficiency. Nat Commun 10:5207

Gaut BS (2002) Evolutionary dynamics of grass genomes. New Phytol 154:15-28

Guo B, Sleper DA, Lu P, Shannon JG, Nguyen HT, Arelli PR (2006) QTL associated with resistance to soybean cyst nematode in soybean: meta-analysis of QTL locations. Crop Sci 46:595-602

Guo J, Shi WP, Zhang Z, Cheng JY, Sun DZ, Yu J, Li XL, Guo PY, Hao CY (2018) Association of yield-related traits in founder genotypes and derivatives of common wheat (Triticum aestivum L.). BMC Plant Biol 18:38

Guo Y, Sun J, Zhang G, Wang Y, Li S (2013) Haplotype, molecular marker and phenotype effects associated with mineral nutrient and grain size traits of TaGS1a in wheat. Field Crop Res 154:119-125

Guo ZF, Chen DJ, Alqudah AM, Roder MS, Ganal MW, Schnurbusch T (2017) Genome-wide association analyses of 54 traits identified multiple loci for the determination of floret fertility in wheat. New Phytol 214:257-270

Gupta PK, Balyan HS, Sharma S, Kumar R (2020) Genetics of yield, abiotic stress tolerance and biofortification in wheat (Triticum aestivum L.). Theor Appl Genet 133:1569-1602 
Hanif M, Gao FM, Liu JD, Wen WE, Zhang YJ, Rasheed A, Xia XC, He ZH, Cao SH (2016) TaTGW6-A1, an ortholog of rice TGW6, is associated with grain weight and yield in bread wheat. Mol Breeding 36:1

International Wheat Genome Sequencing Consortium (IWGSC) (2018) Shifting the limits in wheat research and breeding using a fully annotated reference genome. Science 361:661

Jiang YM, Jiang QY, Hao CY, Hou J, Wang LF, Zhang HN, Zhang SN, Chen XH, Zhang XY (2015) A yield-associated gene TaCWI, in wheat: its function, selection and evolution in global breeding revealed by haplotype analysis. Theor Appl Genet 128:131-143

Khahani B, Tavakol E, Shariati V, Fornara F (2020) Genome wide screening and comparative genome analysis for Meta-QTLs, orthoMQTLs and candidate genes controlling yield and yield-related traits in rice. BMC genomics 21:294

Khowaja F, Norton G, Courtois B, Price A (2009) Improved resolution in the position of drought-related QTLs in a single mapping population of rice by meta-analysis. BMC genomics 10:276

Kumar A, Saripalli G, Jan I, Kumar K, Sharma PK, Balyan HS, Gupta PK (2020) Meta-QTL analysis and identification of candidate genes for drought tolerance in bread wheat (Triticum aestivum L.). Physiol Mol Biol Plants 26:1713-1725

Kwon CT, Kim SH, Kim D, Paek NC (2015) The rice floral repressor early flowering1 effects spikelet fertility by modulating gibberellin signaling. Rice 8:23

Li QY, Li LQ, Liu Y, Lv Q, Zhang H, Zhu J, Li XJ (2017) Influence of TaGW2-6A on seed development in wheat by negatively regulating gibberellin synthesis. Plant Sci 263:226-235

Ling HQ, Zhao SC, Liu DC, Wang JY, Sun H, Zhang C, Fan HJ, Li D, Dong LL, Tao Y, Gao C, Wu HL, Li YW, Cui Y, Guo XS, Zheng SS, Wang B, Yu K, Liang QS, Yang WL, Lou XY, Chen J, Feng MJ, Jian JB, Zhang XF, Luo GB, Jiang Y, Liu JJ, Wang ZB, Sha YH, Zhang BR, Wu HJ, Tang DZ, Shen QH, Xue PY, Zou SH, Wang XJ, Liu X, Wang FM, Yang YP, An XL, Dong ZY, Zhang KP, Zhang XQ, Luo MC, Dvorak J, Tong YP, Wang J, Yang HM, Li ZS, Wang DW, Zhang AM, Wang J (2013) Draft genome of the wheat A-genome progenitor Triticum urartu. Nature 496:87-90

Liu CY, Sukumaran S, Claverie E, Sansaloni C, Dreisigacker S, Reynolds M (2019) Genetic dissection of heat and drought stress QTLs in phenology-controlled synthetic-derived recombinant inbred lines in spring wheat. Mol Breeding 39:34

Liu H, Mullan D, Zhang C, Zhao S, Li X, Zhang A, Lu Z, Wang Y, Yan G (2020) Major genomic regions responsible for wheat yield and its components as revealed by meta-QTL and genotype-phenotype association analyses. Planta 252:65

Liu J, Feng B, Xu ZB, Fan XL, Jiang F, Jin XF, Cao J, Wang F, Liu Q, Yang L, Wang T (2018) A genome-wide association study of wheat yield and quality-related traits in southwest China. Mol Breeding 38:1

Liu JM, Park SJ, Huang J, Lee EJ, Xuan YH, Je BI, Kumar V, Priatama RA, Vimal RK, Kim SH, Min MK, Cho JH, Kim TH, Chandran AKN, Jung KH, Takatsuto S, Fujioka S, Han CD (2016) Loose Plant Architecture1 (LPA1) determines lamina joint bending by suppressing auxin signalling that interacts with C-22-hydroxylated and 6-deoxo brassinosteroids in rice. J Exp Bot 67:1883-1895

Liu Y, Salsman E, Wang R, Galagedara N, Zhang Q, Fiedler JD, Liu Z, Xu S, Faris JD, Li X (2020) Meta-QTL analysis of tan spot resistance in wheat. Theor Appl Genet 133:2363-2375

Lo SF, Yang SY, Chen KT, Hsing YI, Zeevaart JA, Chen LJ, Yu SM (2008) A novel class of gibberellin 2-oxidases control semidwarfism, tillering, and root development in rice. Plant cell 20:2603-2618.

Nadolska-Orczyk A, Rajchel IK, Orczyk W, Gasparis S (2017) Major genes determining yield-related traits in wheat and barley. Theor Appl Genet 130:1081-1098

Pearce S, Huttly AK, Prosser IM, Li YD, Vaughan SP, Gallova B, Patil A, Coghill JA, Dubcovsky J, Hedden P, Phillips AL (2015) Heterologous expression and transcript analysis of gibberellin biosynthetic genes of grasses reveals novel functionality in the

Page $14 / 42$ 
Peng J, Richards DE, Hartley NM, Murphy GP, Devos KM, Flintham JE, Beales J, Fish LJ, Worland AJ, Pelica F, Sudhakar D, Christou P, Snape JW, Gale MD, Harberd NP (1999) Green revolution genes encode mutant gibberellin response modulators. Nature 400:256-261

Qin L, Hao C, Hou J, Wang Y, Li T, Wang L, Ma Z (2014) Homologous haplotypes, expression, genetic effects and geographic distribution of the wheat yield gene TaGW2. BMC Plant Biol 14:107

Quraishi UM, Pont C, Ain Q-u, Flores R, Burlot L, Alaux M, Quesneville H, Salse J (2017) Combined genomic and genetic data integration of major agronomical traits in bread wheat (Triticum aestivum L.). Front Plant Sci 8:1843.

Ramegowda V, Basu S, Krishnan A, Pereira A (2014) Rice GROWTH UNDER DROUGHT KINASE is required for drought tolerance and grain yield under normal and drought stress conditions. Plant Physiol 166:1634-1645

Ramírez-González RH, Borrill P, Lang D, Harrington SA, Brinton J, Venturini L, Davey M, Jacobs J, van Ex F, Pasha A, Khedikar Y, Robinson SJ, Cory AT, Florio T, Concia L, Juery C, Schoonbeek H, Steuernagel B, Xiang D, Ridout CJ, Chalhoub B, Mayer KFX, Benhamed M, Latrasse D, Bendahmane A, Wulff BBH, Appels R, Tiwari V, Datla R, Choulet F, Pozniak CJ, Provart NJ, Sharpe AG, Paux E, Spannagl M, Brautigam A, Uauy C, IWGSC (2018) The transcriptional landscape of polyploid wheat. Science 361:662-+ Ray DK, Mueller ND, West PC, Foley JA (2013) Yield trends are insufficient to double global crop production by 2050. Plos One 8:e66428

Raza Q, Riaz A, Sabar M, Atif RM, Bachir K (2019) Meta-analysis of grain iron and zinc associated QTLs identified hotspot chromosomal regions and positional candidate genes for breeding biofortified rice. Plant Sci 288:110214

Ryu CH, Lee S, Cho LH, Kim SL, Lee YS, Choi SC, Jeong HJ, Yi J, Park SJ, Han CD, An G (2010) OsMADS50 and OsMADS56 function antagonistically in regulating long day (LD)-dependent flowering in rice. Plant Cell Environ 32:1412-1427

Said J, Song M, Wang H, Lin Z, Zhang X, Fang D, Zhang J (2015) A comparative meta-analysis of QTL between intraspecific Gossypium hirsutum and interspecific G. hirsutum × G. barbadense populations. Mol Genet Genomics 290:1003-1025

Saintenac C, Jiang DY, Wang SC, Akhunov E (2013) Sequence-based mapping of the polyploid wheat genome. G3-Genes Genom Genet 3:1105-1114

Silverstone AL, Mak PYA, Martinez EC, Sun TP (1997) The new RGA locus encodes a negative regular of gibberellin response in Arabidopsis thaliana. Genetics 146:1087-1099.

Soriano JM, Alvaro F (2019) Discovering consensus genomic regions in wheat for root-related traits by QTL meta-analysis. Sci Rep 9:10537

Soriano JM, Royo C (2015) Dissecting the genetic architecture of leaf rust resistance in wheat by QTL meta-analysis. Phytopathology 105:1585-1593

Sosnowski O, Charcosset A, Joets J (2012) BioMercator V3: an upgrade of genetic map compilation and quantitative trait loci meta-analysis algorithms. Bioinformatics 28:2082-2083.

Sukumaran S, Dreisigacker S, Lopes M, Chavez P, Reynolds MP (2015) Genome-wide association study for grain yield and related traits in an elite spring wheat population grown in temperate irrigated environments. Theor Appl Genet 128:353-363

Sun C, Zhang F, Yan X, Zhang X, Dong Z, Cui D, Chen F (2017) Genome-wide association study for 13 agronomic traits reveals distribution of superior alleles in bread wheat from the Yellow and Huai Valley of China. Plant Biotechnol J 15:953-969

Sun CW, Dong ZD, Zhao L, Ren Y, Zhang N, Chen F (2020) The Wheat 660K SNP array demonstrates great potential for markerassisted selection in polyploid wheat. Plant Biotechnol J 18:1354-1360 
Tai L, Wang HJ, Xu XJ, Sun WH, Ju L, Liu WT, Li WQ, Sun J, Chen KM (2021) Cereal pre-harvest sprouting: a global agricultural disaster regulated by complex genetic and biochemical mechanisms. J Exp Bot erab024. Doi: 10.1093/jxb/erab024

Tian RZ, Yang Y, Chen MH (2020) Genome-wide survey of the amino acid transporter gene family in wheat (Triticum aestivum L.): Identification, expression analysis and response to abiotic stress. Int J Biol Macromol 162:1372-1387

Tiwari DK, Pandey P, Giri SP, Dwivedi JL (2011) Effect of GA3 and other Plant Growth regulators on Hybrid Rice Seed. Asian Journal of Plant Science 10:133-139

Venske E, Dos_santos RS, Farias DD, Rother V, Maia LC, Pegoraro C and Costa_de_oliveira A (2019) Meta-analysis of the QTLome of Fusarium head blight resistance in bread wheat: refining the current puzzle. Front Plant Sci 10:727

Veyrieras JB, Goffinet B, Charcosset A (2007) MetaQTL: a package of new computational methods for the meta-analysis of QTL mapping experiments. BMC Bioinformatics 8:49

Wang S, Wong D, Forrest K, Allen A, Chao S, Huang BE, Maccaferri M, Salvi S, Milner SG, Cattivelli L, Mastrangelo AM, Whan A, Stephen S, Barker G, Wieseke R, Plieske J, International Wheat Genome Sequencing Consortium, Lillemo M, Mather D, Appels R, Dolferus R, Brown-Guedira G, Korol A, Akhunova AR, Feuillet C, Salse J, Morgante M, Pozniak C, Luo MC, Dvorak J, Morell M, Dubcovsky J, Ganal M, Tuberosa R, Lawley C, Mikoulitch I, Cavanagh C, Edwards KJ, Hayden M, Akhunov E (2014) Characterization of polyploid wheat genomic diversity using a high-density 90000 single nucleotide polymorphism array. Plant Biotechnol J 12:787-796

Wang X, Zhou W, Lu Z, Ouyang Y, O CS, Yao J (2015) A lipid transfer protein, OsLTPL36, is essential for seed development and seed quality in rice. Plant Sci 239:200-208

Wang X, Guan P, Xin M, Wang Y, Chen X, Zhao A, Liu M, Li H, Zhang M, Lu L, Zhang J, Ni Z, Yao Y, Hu Z, Peng H, Sun Q (2020a) Genome-wide association study identifies QTL for thousand grain weight in winter wheat under normal- and late-sown stressed environments. Theor Appl Genet. https://doi.org/10.1007/s00122-020-03687-w

Wang Y, Huang Z, Deng D, Ding H, Zhang R, Wang S, Bian Y, Yin Z, Xu X (2013) Meta-analysis combined with syntenic metaQTL mining dissects candidate loci for maize yield. Mol Breeding 31:601-614

Wang Y, Wang Y, Wang X, Deng D (2020b) Integrated meta-QTL and genome-wide association study analyses reveal candidate genes for maize yield. J Plant Growth Regul 39:229-238

Welcker C, Sadok W, Dignat G, Renault M, Salvi S, Charcosset A, Tardieu F (2011) A common genetic determinism for sensitivities to soil water deficit and evaporative demand: meta-analysis of quantitative trait loci and introgression lines of maize. Plant Physiol 157:718-729

Wu Y, Wang Y, Mi XF, Shan JX, Li XM, Xu JL, Lin HX (2016) The QTL GNP1 encodes GA20ox1, which increases grain number and yield by increasing cytokinin activity in rice panicle meristems. Plos Genet 12:e1006386

Wu J, Yu R, Wang H, Zhou C, Huang S, Jiao H, Yu S, Nie X, Wang Q, Liu S, Weining S, Singh RP, Bhavani S, Kang Z, Han D, Zeng Q (2020) A large-scale genomic association analysis identifies the candidate causal genes conferring stripe rust resistance under multiple field environments. Plant Biotechnol J 1-15

Xiang DQ, Quilichini TD, Liu ZY, Gao P, Pan YL, Li Q, Nilsen KT, Venglat P, Esteban E, Pasha A, Wang YJ, Wen R, Zhang ZJ, Hao ZD, Wang E, Wei YD, Cuthbert R, Kochian LV, Sharpe A, Provart N, Weijers D, Gillmor CS, Pozniak C, Datla R (2019) The Transcriptional Landscape of Polyploid Wheats and Their Diploid Ancestors during Embryogenesis and Grain Development. Plant Cell 31:28882911

Yan L, Loukoianov A, Tranquilli G, Helguera M, Fahima T, Dubcovsky J (2003) Positional cloning of the wheat vernalization gene VRN. Proc Natl Acad Sci USA 10: 6263-6268 
Yan L, Loukoianov A, Blechl A, Tranquilli G, Ramakrishna W, SanMiguel P, Bennetzen JL, Echenique V, Dubcovsky J (2004) The wheat VRN2 gene is a flowering repressor down-regulated by vernalization. Science 303:1640-1644

Yan L, Fu D, Li C, Blechl A, Tranquilli G, Bonafede M, Sanchez A, Valarik M, Yasuda S, Dubcovsky J (2006) The wheat and barley vernalization gene VRN3 is an orthologue of FT. Proc Natl Acad Sci USA 103:19581-19586

Yang Y, Chai Y, Zhang X, Lu S, Zhao Z, Wei D, Chen L, Hu YG (2020) Multi-Locus GWAS of Quality Traits in Bread Wheat: Mining More Candidate Genes and Possible Regulatory Network. Front Plant Sci 11:1091

Yu LX, Barbier H, Rouse MN, Singh S, Singh RP, Bhavani S, Huerta-Espino J, Sorrells ME (2014) A consensus map for Ug99 stem rust resistance loci in wheat. Theor Appl Genet 127:1561-1581

Zanke CD, Ling J, Plieske J, Kollers S, Ebmeyer E, Korzun V, Argillier O, Stiewe G, Hinze M, Neumann F, Eichhorn A, Polley A, Jaenecke C, Ganal MW and Röder MS (2015) Analysis of main effect QTL for thousand grain weight in European winter wheat (Triticum aestivum L.) by genome-wide association mapping. Front Plant Sci 6:644

Zhang JP, Liu WH, Yang XM, Gao AN, Li XQ, Wu XY, Li LH (2011) Isolation and characterization of two putative cytokinin oxidase genes related to grain number per spike phenotype in wheat. Mol Biol Rep 38:2337-2347

Zhang L, Zhao YL, Gao LF, Zhao GY, Zhou RH, Zhang BS, Jia JZ (2012) TaCKX6-D1, the ortholog of rice OsCKX2, is associated with grain weight in hexaploid wheat. New Phytol 195:574-584

Zhang LY, Liu DC, Guo XL, Yang WL, Sun JZ, Wang DW, Zhang A (2010) Genomic distribution of quantitative trait loci for yield and yield-related traits in common wheat. $\mathrm{J}$ Integr Plant Biol 52:996-1007

Zhang X, Shabala S, Koutoulis A, Shabala L, Zhou M (2017) Meta-analysis of major QTL for abiotic stress tolerance in barley and implications for barley breeding. Planta 245:283-295

Zhang YJ, Liu JD, Xia XC, He ZH (2014) TaGS-D1, an ortholog of rice OsGS3, is associated with grain weight and grain length in common wheat. Mol Breeding 34:1097-1107

Zheng T, Hua C, Li L, Sun Z, Yuan M, Bai G, Humphreys G, Li T (2020) Integration of meta-QTL discovery with omics: towards a molecular breeding platform for improving wheat resistance to Fusarium head blight. Crop J Doi:10.1016/j.cj.2020.10.006

\section{Tables}

\section{Table 1. Details of 145 Meta-QTLs for yield and yield-related traits in wheat}




\begin{tabular}{|c|c|c|c|c|c|c|c|c|c|}
\hline No. & $\begin{array}{l}\text { MQTL } \\
\text { ID }\end{array}$ & Chr. $^{a}$ & $\begin{array}{l}\text { Position } \\
(\mathrm{cM})^{\mathrm{b}}\end{array}$ & $\begin{array}{l}\mathrm{Cl} \\
(\mathrm{cM})^{\mathrm{c}}\end{array}$ & $\begin{array}{l}\text { Genetic } \\
\text { interval } \\
\text { (cM) }\end{array}$ & $\begin{array}{l}\text { No. } \\
\text { Of } \\
\text { QTLs }\end{array}$ & Traits $^{d}$ & $\begin{array}{l}\text { Physical } \\
\text { interval } \\
(\mathrm{Mb})\end{array}$ & Flanking markers \\
\hline 1 & $\begin{array}{l}\text { MQTL- } \\
1 A-1\end{array}$ & $1 \mathrm{~A}$ & 15.95 & 2.57 & $\begin{array}{l}14.67- \\
17.24\end{array}$ & 14 & $\begin{array}{l}\text { TN(3), } \\
\text { GW(3), } \\
\text { GFR(2), } \\
\text { TN(2), } \\
\text { SL(2) }\end{array}$ & $\begin{array}{l}3.01- \\
6.15\end{array}$ & $\begin{array}{l}\text { RAC875_rep_c105697_366- } \\
\text { BS00058867_51 }\end{array}$ \\
\hline 2 & $\begin{array}{l}\text { MQTL- } \\
1 A-2\end{array}$ & $1 \mathrm{~A}$ & 36.96 & 1.56 & $\begin{array}{l}36.18- \\
37.74\end{array}$ & 44 & $\begin{array}{l}\text { GW(11), } \\
\text { GN(10), } \\
\text { SLN(6), } \\
\text { TN(5), } \\
\text { SL(4) }\end{array}$ & $\begin{array}{l}12.10- \\
12.51\end{array}$ & $\begin{array}{l}\text { RAC875_c33470_345- } \\
\text { wsnp_Ex_c1137_2183772 }\end{array}$ \\
\hline 3 & $\begin{array}{l}\text { MQTL- } \\
1 A-3\end{array}$ & $1 \mathrm{~A}$ & 47.41 & 3.91 & $\begin{array}{l}45.46- \\
49.37\end{array}$ & 9 & $\begin{array}{l}\text { GW(4), } \\
\text { GN(2), } \\
\text { SLN(2), } \\
\text { TN(1) }\end{array}$ & $\begin{array}{l}20.98- \\
26.96\end{array}$ & $\begin{array}{l}\text { BS00107852_51- } \\
\text { Kukri_c7436_2259 }\end{array}$ \\
\hline 4 & $\begin{array}{l}\text { MQTL- } \\
1 A-4\end{array}$ & $1 \mathrm{~A}$ & 65.85 & 2.17 & $\begin{array}{l}64.77- \\
66.94\end{array}$ & 24 & $\begin{array}{l}\text { GN(5), } \\
\text { Others(4), } \\
\text { SL(3), } \\
\text { GW(3), } \\
\text { TN(2), } \\
\text { GY(2), } \\
\text { SLN(2), } \\
\text { BY(2) }\end{array}$ & $\begin{array}{l}58.17- \\
95.85\end{array}$ & $\begin{array}{l}\text { Ex_c68770_506- } \\
\text { wsnp_Ex_c31525_40302140 }\end{array}$ \\
\hline 5 & $\begin{array}{l}\text { MQTL- } \\
1 A-5\end{array}$ & $1 \mathrm{~A}$ & 112.72 & 0.44 & $\begin{array}{l}112.50- \\
112.94\end{array}$ & 18 & $\begin{array}{l}\mathrm{GW}(5), \\
\mathrm{GY}(4), \\
\mathrm{GN}(3), \\
\mathrm{SL}(2), \\
\mathrm{HI}(2)\end{array}$ & $\begin{array}{l}570.05- \\
582.77\end{array}$ & Xgwm99.1-1863372 \\
\hline 6 & $\begin{array}{l}\text { MQTL- } \\
1 \mathrm{~B}-1\end{array}$ & 1B & 12.75 & 6.87 & $\begin{array}{l}9.32- \\
16.19\end{array}$ & 3 & $\begin{array}{l}\mathrm{FD}(2) \\
\text { SL(1) }\end{array}$ & $\begin{array}{l}4.35- \\
13.63\end{array}$ & BS00022505_51-2321290 \\
\hline 7 & $\begin{array}{l}\text { MQTL- } \\
1 \mathrm{~B}-2\end{array}$ & $1 \mathrm{~B}$ & 27.25 & 3.22 & $\begin{array}{l}25.64- \\
28.86\end{array}$ & 19 & $\begin{array}{l}\text { GW(4), } \\
\text { GY(4), } \\
\text { SLN(3), } \\
\text { TN(3)' } \\
\text { GFR(2) }\end{array}$ & $\begin{array}{l}22.26- \\
37.85\end{array}$ & $1122078-1118988$ \\
\hline 8 & $\begin{array}{l}\text { MQTL- } \\
1 \mathrm{~B}-3\end{array}$ & 1B & 38.37 & 2.85 & $\begin{array}{l}36.95- \\
39.80\end{array}$ & 60 & $\begin{array}{l}\text { GW(12), } \\
\text { TN(12), } \\
\text { GN(8), } \\
\text { GFR(7), } \\
\text { GY(5) }\end{array}$ & $\begin{array}{l}43.50- \\
69.26\end{array}$ & $1242179-1127010$ \\
\hline 9 & $\begin{array}{l}\text { MQTL- } \\
1 \mathrm{~B}-4\end{array}$ & 1B & 48.37 & 3.01 & $\begin{array}{l}46.87- \\
49.88\end{array}$ & 11 & $\begin{array}{l}\text { GN(4), } \\
\text { GW(3), } \\
\text { TN(1), } \\
\text { GY(1), } \\
\text { SLN(1), } \\
\text { BY(1) }\end{array}$ & $\begin{array}{l}542.93- \\
563.07\end{array}$ & BS00038643_51-989671 \\
\hline 10 & $\begin{array}{l}\text { MQTL- } \\
1 \mathrm{~B}-5\end{array}$ & 1B & 55.46 & 4.09 & $\begin{array}{l}53.42- \\
57.51\end{array}$ & 7 & $\begin{array}{l}\text { GW(3), } \\
\text { GY(3), } \\
\text { SL(1) }\end{array}$ & $\begin{array}{l}587.05- \\
606.49\end{array}$ & 4989515-wPt-9409 \\
\hline 11 & $\begin{array}{l}\text { MQTL- } \\
1 \mathrm{~B}-6\end{array}$ & 1B & 76.65 & 0.31 & $\begin{array}{l}76.50- \\
76.81\end{array}$ & 19 & $\begin{array}{l}\text { GN(4), } \\
\text { GW(4), } \\
\text { SLN(3), } \\
\text { TN(3), } \\
\text { GFR(2), } \\
\text { GY(2) }\end{array}$ & $\begin{array}{l}652.45- \\
659.54\end{array}$ & Excalibur_c49496_705-1071326 \\
\hline
\end{tabular}




\begin{tabular}{|c|c|c|c|c|c|c|c|c|c|}
\hline No. & $\begin{array}{l}\text { MQTL } \\
\text { ID }\end{array}$ & $\mathrm{Chr}^{\mathrm{a}}$ & $\begin{array}{l}\text { Position } \\
(\mathrm{cM})^{\mathrm{b}}\end{array}$ & $\begin{array}{l}\mathrm{Cl} \\
(\mathrm{cM})^{\mathrm{c}}\end{array}$ & $\begin{array}{l}\text { Genetic } \\
\text { interval } \\
\text { (cM) }\end{array}$ & $\begin{array}{l}\text { No. } \\
\text { Of } \\
\text { QTLs }\end{array}$ & Traits $^{d}$ & $\begin{array}{l}\text { Physical } \\
\text { interval } \\
(\mathrm{Mb})\end{array}$ & Flanking markers \\
\hline 12 & $\begin{array}{l}\text { MQTL- } \\
\text { 1D-1 }\end{array}$ & 1D & 24.46 & 4.14 & $\begin{array}{l}22.39- \\
26.53\end{array}$ & 8 & $\begin{array}{l}\text { GW(4), } \\
\text { TN(2), } \\
\text { GN(2) }\end{array}$ & $\begin{array}{l}2.51- \\
10.66\end{array}$ & Xwmc336-1126512 \\
\hline 13 & $\begin{array}{l}\text { MQTL- } \\
1 \mathrm{D}-2\end{array}$ & 1D & 46.53 & 7.84 & $\begin{array}{l}42.61- \\
50.45\end{array}$ & 4 & $\begin{array}{l}\text { GW(2), } \\
\mathrm{TN}(2),\end{array}$ & $\begin{array}{l}10.76- \\
18.07\end{array}$ & $\begin{array}{l}\text { Excalibur_c101903_734- } \\
\text { Excalibur_c48750_124 }\end{array}$ \\
\hline 14 & $\begin{array}{l}\text { MQTL- } \\
1 \mathrm{D}-3\end{array}$ & 1D & 62.24 & 5.85 & $\begin{array}{l}59.32- \\
65.17\end{array}$ & 7 & $\begin{array}{l}\text { TN(3), } \\
\text { GW(2), } \\
\text { GY(1), } \\
\text { GFR(1) }\end{array}$ & $\begin{array}{l}16.89- \\
31.42\end{array}$ & $\begin{array}{l}\text { 1093904- } \\
\text { wsnp_Ex_rep_c101500_86856089 }\end{array}$ \\
\hline 15 & $\begin{array}{l}\text { MQTL- } \\
1 D-4\end{array}$ & 1D & 74.92 & 6.53 & $\begin{array}{l}71.66- \\
78.19\end{array}$ & 3 & $\begin{array}{l}\text { GY(2), } \\
\text { TN(1) }\end{array}$ & $\begin{array}{l}420.54- \\
433.37\end{array}$ & Kukri_c12183_262-994639 \\
\hline 16 & $\begin{array}{l}\text { MQTL- } \\
1 D-5\end{array}$ & $1 \mathrm{D}$ & 86 & 5.06 & $\begin{array}{l}83.47- \\
88.53\end{array}$ & 9 & $\begin{array}{l}\text { GW(4), } \\
\text { GN(1), } \\
\text { GY(1), } \\
\text { SL(1), } \\
\text { SLN(1), } \\
\text { DTH(1) }\end{array}$ & $\begin{array}{l}442.05- \\
452.43\end{array}$ & $1104328-1238564$ \\
\hline 17 & $\begin{array}{l}\text { MQTL- } \\
1 D-6\end{array}$ & $1 \mathrm{D}$ & 107.31 & 4.68 & $\begin{array}{l}104.97- \\
109.65\end{array}$ & 5 & $\begin{array}{l}\text { SL(2), } \\
\text { GY(1), } \\
\text { GW(1), } \\
\text { SLN(1) }\end{array}$ & $\begin{array}{l}458.12- \\
465.35\end{array}$ & $2252079-2246395$ \\
\hline 18 & $\begin{array}{l}\text { MQTL- } \\
1 D-7\end{array}$ & $1 \mathrm{D}$ & 127.92 & 2.04 & $\begin{array}{l}126.90- \\
128.94\end{array}$ & 2 & $\begin{array}{l}\mathrm{DTH}(1) \\
\mathrm{GW}(1)\end{array}$ & $\begin{array}{l}485.96- \\
494.47\end{array}$ & 1122218-RAC875_c37075_53 \\
\hline 19 & $\begin{array}{l}\text { MQTL- } \\
2 A-1\end{array}$ & $2 A$ & 13.29 & 1.85 & $\begin{array}{l}12.37- \\
14.22\end{array}$ & 17 & $\begin{array}{l}\text { GW(9), } \\
\text { GFR(5), } \\
\text { GN(1), } \\
\text { GY(1)', } \\
\text { DTM(1) }\end{array}$ & $\begin{array}{l}59.38- \\
71.58\end{array}$ & 986207-1084359 \\
\hline 20 & $\begin{array}{l}\text { MQTL- } \\
2 A-2\end{array}$ & $2 A$ & 30.92 & 1.84 & $\begin{array}{l}30.00- \\
31.84\end{array}$ & 21 & $\begin{array}{l}\text { GY(7), } \\
\text { GN(3), } \\
\text { GW(3), } \\
\text { GFR(2), } \\
\text { BY(2), } \\
\text { Others(2) }\end{array}$ & $\begin{array}{l}3.95- \\
10.01\end{array}$ & 1088217-1162905 \\
\hline 21 & $\begin{array}{l}\text { MQTL- } \\
2 A-3\end{array}$ & $2 \mathrm{~A}$ & 43.7 & 1.41 & $\begin{array}{l}43.00- \\
44.41\end{array}$ & 5 & $\begin{array}{l}\mathrm{GW}(3), \\
\mathrm{GY}(1), \\
\mathrm{GN}(1)\end{array}$ & $\begin{array}{l}27.97- \\
30.45\end{array}$ & $\begin{array}{l}\text { RAC875_rep_c111906_144- } \\
\text { wsnp_Ex_c61879_61748626 }\end{array}$ \\
\hline 22 & $\begin{array}{l}\text { MQTL- } \\
2 A-4\end{array}$ & $2 \mathrm{~A}$ & 50.07 & 0.95 & $\begin{array}{l}49.60- \\
50.55\end{array}$ & 60 & $\begin{array}{l}\text { GW(19), } \\
\text { GN(14), } \\
\text { SL(7), } \\
\text { GY(6), } \\
\text { SLN(6) }\end{array}$ & $\begin{array}{l}33.27- \\
34.50\end{array}$ & $\begin{array}{l}\text { CAP12_rep_c4192_354-- } \\
\text { Ku_c23118_149 }\end{array}$ \\
\hline 23 & $\begin{array}{l}\text { MQTL- } \\
2 A-5\end{array}$ & $2 \mathrm{~A}$ & 56.42 & 2.14 & $\begin{array}{l}55.35- \\
57.49\end{array}$ & 7 & $\begin{array}{l}\text { GW(3), } \\
\text { GN(2), } \\
\text { GY(1), } \\
\text { Others(1) }\end{array}$ & $\begin{array}{l}36.05- \\
38.32\end{array}$ & $\begin{array}{l}\text { wsnp_Ex_c19556_28530243- } \\
\text { Tdurum_contig30725_220 }\end{array}$ \\
\hline 24 & $\begin{array}{l}\text { MQTL- } \\
2 A-6\end{array}$ & $2 \mathrm{~A}$ & 80.67 & 5.35 & $\begin{array}{l}78.00- \\
83.35\end{array}$ & 5 & $\begin{array}{l}\text { GW(3), } \\
\operatorname{TN}(1), \\
\text { SLN(1) }\end{array}$ & $\begin{array}{l}706.00- \\
737.43\end{array}$ & $2260254-3026394$ \\
\hline
\end{tabular}




\begin{tabular}{|c|c|c|c|c|c|c|c|c|c|}
\hline No. & $\begin{array}{l}\text { MQTL } \\
\text { ID }\end{array}$ & $\mathrm{Chr}^{\mathrm{a}}$ & $\begin{array}{l}\text { Position } \\
\text { (cM) }^{\mathrm{b}}\end{array}$ & $\begin{array}{l}\mathrm{Cl} \\
(\mathrm{cM})^{\mathrm{c}}\end{array}$ & $\begin{array}{l}\text { Genetic } \\
\text { interval } \\
\text { (cM) }\end{array}$ & $\begin{array}{l}\text { No. } \\
\text { Of } \\
\text { QTLs }\end{array}$ & Traits $^{d}$ & $\begin{array}{l}\text { Physical } \\
\text { interval } \\
(\mathrm{Mb})\end{array}$ & Flanking markers \\
\hline 25 & $\begin{array}{l}\text { MQTL- } \\
2 A-7\end{array}$ & $2 \mathrm{~A}$ & 100.72 & 0.33 & $\begin{array}{l}100.56- \\
100.89\end{array}$ & 15 & $\begin{array}{l}\mathrm{GW}(7), \\
\mathrm{TN}(2), \\
\mathrm{SL}(2), \\
\mathrm{GN}(2), \\
\mathrm{GY}(1), \\
\mathrm{HI}(1)\end{array}$ & $\begin{array}{l}721.56- \\
723.82\end{array}$ & $\begin{array}{l}\text { RAC875_c16333_340-- } \\
\text { RFL_Contig3509_229 }\end{array}$ \\
\hline 26 & $\begin{array}{l}\text { MQTL- } \\
\text { 2B-1 }\end{array}$ & 2B & 50.7 & 11.44 & $\begin{array}{l}44.98- \\
56.42\end{array}$ & 40 & $\begin{array}{l}\text { GN(9), } \\
\text { GW(6), } \\
\text { SLN(4), } \\
\text { DHT(4), } \\
\text { GY(4) }\end{array}$ & $\begin{array}{l}6.21- \\
17.57\end{array}$ & $\begin{array}{l}\text { RAC875_c65386_72- } \\
\text { BS00022298_51 }\end{array}$ \\
\hline 27 & $\begin{array}{l}\text { MQTL- } \\
\text { 2B-2 }\end{array}$ & $2 B$ & 71.64 & 9.15 & $\begin{array}{l}67.07- \\
76.22\end{array}$ & 40 & $\begin{array}{l}\text { GW(15), } \\
\text { GN(8), } \\
\text { SLN(4), } \\
\text { GY(2), } \\
\text { Others(2) }\end{array}$ & $\begin{array}{l}26.58- \\
30.50\end{array}$ & $\begin{array}{l}\text { BS00065040_51- } \\
\text { Tdurum_contig54634_846 }\end{array}$ \\
\hline 28 & $\begin{array}{l}\text { MQTL- } \\
2 B-3\end{array}$ & $2 B$ & 95.09 & 8.96 & $\begin{array}{l}90.61- \\
99.57\end{array}$ & 23 & $\begin{array}{l}\text { GW(7), } \\
\text { TN(5), } \\
\text { GN(5), } \\
\text { DTH(3), } \\
\text { GY(2) }\end{array}$ & $\begin{array}{l}50.71- \\
80.12\end{array}$ & $4911198-1210486$ \\
\hline 29 & $\begin{array}{l}\text { MQTL- } \\
2 \mathrm{~B}-4\end{array}$ & $2 B$ & 109.36 & 9.51 & $\begin{array}{l}104.61- \\
114.12\end{array}$ & 30 & $\begin{array}{l}\text { GW(12), } \\
\text { GY(9), } \\
\text { GN(3), } \\
\text { DTH(2), } \\
\text { TN(1), } \\
\text { BY(1), } \\
\text { FD(1), } \\
\text { Others(1) }\end{array}$ & $\begin{array}{l}104.06- \\
730.19\end{array}$ & $\begin{array}{l}\text { Tdurum_contig62852_302-- } \\
\text { BS00022713_51 }\end{array}$ \\
\hline 30 & $\begin{array}{l}\text { MQTL- } \\
\text { 2B-5 }\end{array}$ & 2B & 142.27 & 7.34 & $\begin{array}{l}138.60- \\
145.94\end{array}$ & 8 & $\begin{array}{l}\text { GN(3), } \\
\text { SL(2), } \\
\text { Others(2), } \\
\text { GW(1) }\end{array}$ & $\begin{array}{l}795.21- \\
801.25\end{array}$ & $2292261-1211409$ \\
\hline 31 & $\begin{array}{l}\text { MQTL- } \\
2 D-1\end{array}$ & 2D & 1.81 & 1.59 & $\begin{array}{l}1.02- \\
2.61\end{array}$ & 14 & $\begin{array}{l}\text { GW(5), } \\
\text { SL(3), } \\
\text { Others(2), } \\
\text { SLN(2), } \\
\text { GY(1), } \\
\text { HI(1) }\end{array}$ & $\begin{array}{l}2.69- \\
8.98\end{array}$ & $\begin{array}{l}\text { 2243439- } \\
\text { D_GDEEGVY02I0IOX_61 }\end{array}$ \\
\hline 32 & $\begin{array}{l}\text { MQTL- } \\
2 D-2\end{array}$ & $2 D$ & 5.31 & 1.03 & $\begin{array}{l}4.80- \\
5.83\end{array}$ & 82 & $\begin{array}{l}\text { GW(26), } \\
\text { SL(15), } \\
\text { GN(8), } \\
\text { TN(7); } \\
\text { GY(6)' }\end{array}$ & $\begin{array}{l}5.44- \\
10.32\end{array}$ & D_contig74612_253-2243548 \\
\hline 33 & $\begin{array}{l}\text { MQTL- } \\
2 D-3\end{array}$ & 2D & 16.1 & 2.37 & $\begin{array}{l}14.92- \\
17.29\end{array}$ & 22 & $\begin{array}{l}\mathrm{GW}(8) \\
\operatorname{SL}(4)\end{array}$ & $\begin{array}{l}24.98- \\
28.76\end{array}$ & $\begin{array}{l}\text { 3222417- } \\
\text { D_GA8KES401CIV9Z_240 }\end{array}$ \\
\hline 34 & $\begin{array}{l}\text { MQTL- } \\
2 D-4\end{array}$ & 2D & 25.82 & 3.47 & $\begin{array}{l}24.09- \\
27.56\end{array}$ & 10 & $\begin{array}{l}\text { GW(3), } \\
\text { TN(3), } \\
\text { SLN(2), } \\
\text { GN(1), } \\
\text { SL(1) }\end{array}$ & $\begin{array}{l}28.88- \\
36.42\end{array}$ & $1282771-983316$ \\
\hline 35 & $\begin{array}{l}\text { MQTL- } \\
2 \mathrm{D}-5\end{array}$ & $2 \mathrm{D}$ & 41.68 & 1.57 & $\begin{array}{l}40.90- \\
42.47\end{array}$ & 14 & $\begin{array}{l}\text { GY(3), } \\
\text { GW(2), } \\
\text { DTH(2), } \\
\text { DTM(2), } \\
\text { FD(2) }\end{array}$ & $\begin{array}{l}52.52- \\
70.51\end{array}$ & $1179088-1044037$ \\
\hline
\end{tabular}




\begin{tabular}{|c|c|c|c|c|c|c|c|c|c|}
\hline No. & $\begin{array}{l}\text { MQTL } \\
\text { ID }\end{array}$ & $\mathrm{Chr}^{\mathrm{a}}$ & $\begin{array}{l}\text { Position } \\
(\mathrm{cM})^{\mathrm{b}}\end{array}$ & $\begin{array}{l}\mathrm{Cl} \\
(\mathrm{cM})^{\mathrm{c}}\end{array}$ & $\begin{array}{l}\text { Genetic } \\
\text { interval } \\
\text { (cM) }\end{array}$ & $\begin{array}{l}\text { No. } \\
\text { Of } \\
\text { QTLs }\end{array}$ & Traits $^{d}$ & $\begin{array}{l}\text { Physical } \\
\text { interval } \\
(\mathrm{Mb})\end{array}$ & Flanking markers \\
\hline 36 & $\begin{array}{l}\text { MQTL- } \\
2 D-6\end{array}$ & $2 \mathrm{D}$ & 72.57 & 0.18 & $\begin{array}{l}72.48- \\
72.66\end{array}$ & 22 & $\begin{array}{l}\text { GW(9), } \\
\text { GY(7), } \\
\text { SL(2), } \\
\text { GN(1), } \\
\text { BY(1), } \\
\text { DTH(1), } \\
\text { Others(1) }\end{array}$ & $\begin{array}{l}562.84- \\
572.07\end{array}$ & $2249848-732882$ \\
\hline 37 & $\begin{array}{l}\text { MQTL- } \\
3 A-1\end{array}$ & $3 \mathrm{~A}$ & 19.4 & 2.01 & $\begin{array}{l}18.40- \\
20.41\end{array}$ & 21 & $\begin{array}{l}\text { GW(7), } \\
\text { GY(5), } \\
\text { GN(5), } \\
\text { TN(3), } \\
\text { DTH(1) }\end{array}$ & $\begin{array}{l}12.83- \\
20.34\end{array}$ & 1370787-1113547 \\
\hline 38 & $\begin{array}{l}\text { MQTL- } \\
3 A-2\end{array}$ & $3 \mathrm{~A}$ & 36.55 & 3.52 & $\begin{array}{l}34.79- \\
38.31\end{array}$ & 9 & $\begin{array}{l}\text { GY(3), } \\
\text { GN(3), } \\
\text { GW(2), } \\
\text { TN(1) }\end{array}$ & $\begin{array}{l}26.19- \\
32.17\end{array}$ & Excalibur_c55624_86-1117391 \\
\hline 39 & $\begin{array}{l}\text { MQTL- } \\
3 A-3\end{array}$ & $3 \mathrm{~A}$ & 55.85 & 2.64 & $\begin{array}{l}54.53- \\
57.17\end{array}$ & 9 & $\begin{array}{l}\text { TN(3), } \\
\text { GY(2), } \\
\text { DTH(2), } \\
\text { SL(1), } \\
\text { GW(1) }\end{array}$ & $\begin{array}{l}471.36- \\
533.62\end{array}$ & $\begin{array}{l}\text { wsnp_CAP11_c2438_1258747- } \\
\text { RAC875_c62909_192 }\end{array}$ \\
\hline 40 & $\begin{array}{l}\text { MQTL- } \\
3 A-4\end{array}$ & $3 \mathrm{~A}$ & 62.06 & 1.48 & $\begin{array}{l}61.32- \\
62.80\end{array}$ & 44 & $\begin{array}{l}\text { GN(10), } \\
\text { TN(9), } \\
\text { GW(7), } \\
\text { GY(7), } \\
\text { HI(3), }\end{array}$ & $\begin{array}{l}628.70- \\
645.40\end{array}$ & $\begin{array}{l}\text { Kukri_rep_c116421_403-wPt- } \\
5084\end{array}$ \\
\hline 41 & $\begin{array}{l}\text { MQTL- } \\
3 A-5\end{array}$ & $3 \mathrm{~A}$ & 66.76 & 1.94 & $\begin{array}{l}65.79- \\
67.73\end{array}$ & 23 & $\begin{array}{l}\text { GN(8), } \\
\text { GW(7), } \\
\text { TN(3), } \\
\text { GY(2), } \\
\text { HI(1), } \\
\text { FD(1), } \\
\text { Others(1) }\end{array}$ & $\begin{array}{l}647.47- \\
657.95\end{array}$ & $\begin{array}{l}\text { Excalibur_c39002_242- } \\
\text { wsnp_BQ167580A_Ta_1_1 }\end{array}$ \\
\hline 42 & $\begin{array}{l}\text { MQTL- } \\
3 A-6\end{array}$ & $3 \mathrm{~A}$ & 81.36 & 2.63 & $\begin{array}{l}80.05- \\
82.68\end{array}$ & 18 & $\begin{array}{l}\text { TN(6), } \\
\text { GW(5), } \\
\text { GY(2), } \\
\text { DTH(2), } \\
\text { HI(1), } \\
\text { BY(1), } \\
\text { FD(1) }\end{array}$ & $\begin{array}{l}688.68- \\
707.99\end{array}$ & RFL_Contig4282_1420-wPt-3697 \\
\hline 43 & $\begin{array}{l}\text { MQTL- } \\
3 A-7\end{array}$ & $3 \mathrm{~A}$ & 118.36 & 1.33 & $\begin{array}{l}117.70- \\
119.03\end{array}$ & 5 & $\begin{array}{l}\mathrm{GN}(4) \\
\mathrm{GY}(1)\end{array}$ & $\begin{array}{l}736.10- \\
745.53\end{array}$ & $1083178-2266354$ \\
\hline 44 & $\begin{array}{l}\text { MQTL- } \\
\text { 3B-1 }\end{array}$ & 3B & 6.84 & 1.83 & $\begin{array}{l}5.93- \\
7.76\end{array}$ & 15 & $\begin{array}{l}\text { GW(7), } \\
\text { GN(4), } \\
\text { GFR(3) }\end{array}$ & $\begin{array}{l}2.51- \\
4.43\end{array}$ & $\begin{array}{l}\text { BS00094406_51- } \\
\text { Kukri_c32803_150 }\end{array}$ \\
\hline 45 & $\begin{array}{l}\text { MQTL- } \\
\text { 3B-2 }\end{array}$ & 3B & 19.56 & 2.49 & $\begin{array}{l}18.32- \\
20.81\end{array}$ & 18 & $\begin{array}{l}\text { GW(5), } \\
\text { GN(4), } \\
\text { GY(4), } \\
\text { TN(1), } \\
\text { SL(1), } \\
\text { SLN(1), } \\
\text { BY(1), } \\
\text { Others(1) }\end{array}$ & $\begin{array}{l}3.30- \\
7.07\end{array}$ & 1140438-993177 \\
\hline 46 & $\begin{array}{l}\text { MQTL- } \\
\text { 3B-3 }\end{array}$ & 3B & 32.93 & 5.06 & $\begin{array}{l}30.40- \\
35.46\end{array}$ & 8 & $\begin{array}{l}\text { GW(4), } \\
\text { GY(2), } \\
\text { SL(1), } \\
\text { GFR(1) }\end{array}$ & $\begin{array}{l}12.32- \\
26.81\end{array}$ & wPt-742648-wPt-0267 \\
\hline
\end{tabular}




\begin{tabular}{|c|c|c|c|c|c|c|c|c|c|}
\hline No. & $\begin{array}{l}\text { MQTL } \\
\text { ID }\end{array}$ & Chr. $^{a}$ & $\begin{array}{l}\text { Position } \\
(\mathrm{cM})^{\mathrm{b}}\end{array}$ & $\begin{array}{l}\mathrm{Cl} \\
(\mathrm{cM})^{\mathrm{c}}\end{array}$ & $\begin{array}{l}\text { Genetic } \\
\text { interval } \\
\text { (cM) }\end{array}$ & $\begin{array}{l}\text { No. } \\
\text { Of } \\
\text { QTLs }\end{array}$ & Traits $^{d}$ & $\begin{array}{l}\text { Physical } \\
\text { interval } \\
(\mathrm{Mb})\end{array}$ & Flanking markers \\
\hline 47 & $\begin{array}{l}\text { MQTL- } \\
\text { 3B-4 }\end{array}$ & 3B & 59.07 & 1.74 & $\begin{array}{l}58.20- \\
59.94\end{array}$ & 48 & $\begin{array}{l}\text { GW(13), } \\
\text { GY(10), } \\
\text { GN(9), } \\
\text { SL(5), } \\
\text { HI(3) }\end{array}$ & $\begin{array}{l}63.40- \\
82.45\end{array}$ & 1052877-wPt-1159 \\
\hline 48 & $\begin{array}{l}\text { MQTL- } \\
\text { 3B-5 }\end{array}$ & 3B & 69.47 & 2.26 & $\begin{array}{l}68.34- \\
70.60\end{array}$ & 26 & $\begin{array}{l}\text { TN(9), } \\
\text { GW(4), } \\
\text { BY(3); } \\
\text { FD(3); } \\
\text { GY(2); } \\
\text { DTH(2) }\end{array}$ & $\begin{array}{l}531.23- \\
555.09\end{array}$ & $\begin{array}{l}\text { 1081121- } \\
\text { wsnp_Ex_c14162_22093694 }\end{array}$ \\
\hline 49 & $\begin{array}{l}\text { MQTL- } \\
3 B-6\end{array}$ & 3B & 97.61 & 3.25 & $\begin{array}{l}95.99- \\
99.24\end{array}$ & 11 & $\begin{array}{l}\text { GY(2), } \\
\text { GN(2), } \\
\text { SL(2), } \\
\text { GW(1), } \\
\text { TN(1), } \\
\text { SLN(1), } \\
\text { HI(1), } \\
\text { BY(1) }\end{array}$ & $\begin{array}{l}750.46- \\
763.27\end{array}$ & $2275568-3064709$ \\
\hline 50 & $\begin{array}{l}\text { MQTL- } \\
\text { 3B-7 }\end{array}$ & 3B & 124.6 & 0.36 & $\begin{array}{l}124.42- \\
124.78\end{array}$ & 16 & $\begin{array}{l}\text { GN(6), } \\
\text { GY(4), } \\
\text { GW(3), } \\
\text { Others(2), } \\
\text { HI(1) }\end{array}$ & $\begin{array}{l}789.50- \\
795.85\end{array}$ & wPt-8752-1202216 \\
\hline 51 & $\begin{array}{l}\text { MQTL- } \\
3 D-1\end{array}$ & $3 D$ & 12.31 & 7.12 & $\begin{array}{l}8.75- \\
15.87\end{array}$ & 7 & $\begin{array}{l}\mathrm{GN}(2), \\
\mathrm{GW}(2), \\
\mathrm{TN}(1), \\
\mathrm{GFR}(1), \\
\text { DTH(1) }\end{array}$ & $\begin{array}{l}11.36- \\
22.67\end{array}$ & $1077175-1109353$ \\
\hline 52 & $\begin{array}{l}\text { MQTL- } \\
3 D-2\end{array}$ & $3 \mathrm{D}$ & 44.31 & 2.28 & $\begin{array}{l}43.17- \\
45.45\end{array}$ & 33 & $\begin{array}{l}\text { GW(9), } \\
\text { TN(7), } \\
\text { GN(5), } \\
\text { GY(5), } \\
\text { SLN(4) }\end{array}$ & $\begin{array}{l}54.77- \\
79.62\end{array}$ & $1670270-981840$ \\
\hline 53 & $\begin{array}{l}\text { MQTL- } \\
3 D-3\end{array}$ & $3 D$ & 63.3 & 8.14 & $\begin{array}{l}59.23- \\
67.37\end{array}$ & 7 & $\begin{array}{l}\mathrm{GW}(2), \\
\mathrm{GY}(2), \\
\mathrm{GN}(1) \\
\mathrm{SLN}(1) \\
\mathrm{BY}(1)\end{array}$ & $\begin{array}{l}485.36- \\
509.21\end{array}$ & 3950829-989745 \\
\hline 54 & $\begin{array}{l}\text { MQTL- } \\
3 D-4\end{array}$ & $3 D$ & 120.28 & 3.15 & $\begin{array}{l}118.71- \\
121.86\end{array}$ & 5 & $\begin{array}{l}\mathrm{GW}(4), \\
\mathrm{SL}(1)\end{array}$ & $\begin{array}{l}604.89- \\
613.62\end{array}$ & BS00062684_51-1140647 \\
\hline 55 & $\begin{array}{l}\text { MQTL- } \\
4 A-1\end{array}$ & $4 \mathrm{~A}$ & 16.35 & 2.37 & $\begin{array}{l}15.17- \\
17.54\end{array}$ & 10 & $\begin{array}{l}\text { GW(5), } \\
\text { SL(2), } \\
\text { GN(1), } \\
\text { GY(1), } \\
\text { SLN(1) }\end{array}$ & $\begin{array}{l}7.15- \\
26.63\end{array}$ & 981760-Ex_c864_653 \\
\hline 56 & $\begin{array}{l}\text { MQTL- } \\
4 A-2\end{array}$ & $4 \mathrm{~A}$ & 22.57 & 3.37 & $\begin{array}{l}20.89- \\
24.26\end{array}$ & 19 & $\begin{array}{l}\text { GN(5), } \\
\text { SLN(3), } \\
\text { GW(3), } \\
\text { GY(3), } \\
\text { SL(2) }\end{array}$ & $\begin{array}{l}606.66- \\
611.07\end{array}$ & WMC650-1116187 \\
\hline 57 & $\begin{array}{l}\text { MQTL- } \\
4 A-3\end{array}$ & $4 \mathrm{~A}$ & 29.05 & 2.66 & $\begin{array}{l}27.72- \\
30.38\end{array}$ & 11 & $\begin{array}{l}\text { GW(7), } \\
\text { GN(1), } \\
\text { SL(1), } \\
\text { SLN(1), } \\
\text { Others(1) }\end{array}$ & $\begin{array}{l}590.98- \\
597.06\end{array}$ & $3935226-3024805$ \\
\hline
\end{tabular}




\begin{tabular}{|c|c|c|c|c|c|c|c|c|c|}
\hline No. & $\begin{array}{l}\text { MQTL } \\
\text { ID }\end{array}$ & $\mathrm{Chr}^{\mathrm{a}}$ & $\begin{array}{l}\text { Position } \\
(\mathrm{cM})^{\mathrm{b}}\end{array}$ & $\begin{array}{l}\mathrm{Cl} \\
(\mathrm{cM})^{\mathrm{c}}\end{array}$ & $\begin{array}{l}\text { Genetic } \\
\text { interval } \\
\text { (cM) }\end{array}$ & $\begin{array}{l}\text { No. } \\
\text { Of } \\
\text { QTLs }\end{array}$ & Traits $^{d}$ & $\begin{array}{l}\text { Physical } \\
\text { interval } \\
\text { (Mb) }\end{array}$ & Flanking markers \\
\hline 58 & $\begin{array}{l}\text { MQTL- } \\
4 A-4\end{array}$ & $4 \mathrm{~A}$ & 41.36 & 3.51 & $\begin{array}{l}39.61- \\
43.12\end{array}$ & 20 & $\begin{array}{l}\text { GW(4), } \\
\text { GN(4), } \\
\text { SL(4), } \\
\text { GY(3), } \\
\text { DTM(2) }\end{array}$ & $\begin{array}{l}618.27- \\
621.74\end{array}$ & $3022783-1235138$ \\
\hline 59 & $\begin{array}{l}\text { MQTL- } \\
4 A-5\end{array}$ & $4 \mathrm{~A}$ & 48.59 & 8.47 & $\begin{array}{l}44.36- \\
52.83\end{array}$ & 4 & $\begin{array}{l}\mathrm{GN}(3) \\
\mathrm{GW}(1)\end{array}$ & $\begin{array}{l}\text { 616.59- } \\
626.75\end{array}$ & $1095229-1102703$ \\
\hline 60 & $\begin{array}{l}\text { MQTL- } \\
4 A-6\end{array}$ & $4 \mathrm{~A}$ & 57.56 & 3.07 & $\begin{array}{l}56.03- \\
59.10\end{array}$ & 44 & $\begin{array}{l}\text { GW(13), } \\
\text { GN(9), } \\
\text { SL(6), } \\
\text { SLN(6), } \\
\text { GY(5) }\end{array}$ & $\begin{array}{l}654.45- \\
668.75\end{array}$ & Excalibur_s101731_92-1134812 \\
\hline 61 & $\begin{array}{l}\text { MQTL- } \\
4 A-7\end{array}$ & $4 \mathrm{~A}$ & 67.82 & 3.96 & $\begin{array}{l}65.84- \\
69.80\end{array}$ & 14 & $\begin{array}{l}\text { GY(4), } \\
\text { GN(3), } \\
\text { GW(3), } \\
\text { TN(2), } \\
\text { SL(1), } \\
\text { BY(1) }\end{array}$ & $\begin{array}{l}704.35- \\
737.50\end{array}$ & wPt-734161-Xwmc500 \\
\hline 62 & $\begin{array}{l}\text { MQTL- } \\
4 A-8\end{array}$ & 4A & 93.54 & 0.6 & $\begin{array}{l}93.24- \\
93.84\end{array}$ & 9 & $\begin{array}{l}\text { TN(2), } \\
\text { SL(2), } \\
\text { others(2), } \\
\text { GN(1), } \\
\text { GY(1)' } \\
\text { SLN(1) }\end{array}$ & $\begin{array}{l}726.09- \\
737.53\end{array}$ & Xbarc327-Xbarc52 \\
\hline 63 & $\begin{array}{l}\text { MQTL- } \\
\text { 4B-1 }\end{array}$ & 4B & 10.5 & 2.78 & $\begin{array}{l}9.11- \\
11.89\end{array}$ & 7 & $\begin{array}{l}\text { GW(4), } \\
\text { GN(2), } \\
\text { DTM(1) }\end{array}$ & $\begin{array}{l}2.14- \\
5.47\end{array}$ & tPt-513529-BS00039935_51 \\
\hline 64 & $\begin{array}{l}\text { MQTL- } \\
4 \mathrm{~B}-2\end{array}$ & 4B & 28.21 & 1.96 & $\begin{array}{l}27.23- \\
29.19\end{array}$ & 69 & $\begin{array}{l}\text { GW(23), } \\
\text { GN(17), } \\
\text { TN(8), } \\
\text { SL(7), } \\
\text { GY(4) }\end{array}$ & $\begin{array}{l}14.02- \\
30.86\end{array}$ & Rht-B1-1110817 \\
\hline 65 & $\begin{array}{l}\text { MQTL- } \\
4 \mathrm{~B}-3\end{array}$ & $4 \mathrm{~B}$ & 41.45 & 1.02 & $\begin{array}{l}40.94- \\
41.96\end{array}$ & 32 & $\begin{array}{l}\text { GW(9), } \\
\text { TN(7), } \\
\text { GY(6), } \\
\text { GN(5), } \\
\text { SLN(2) }\end{array}$ & $\begin{array}{l}21.57- \\
24.56\end{array}$ & $\begin{array}{l}\text { 1233562-- } \\
\text { Tdurum_contig41902_1524 }\end{array}$ \\
\hline 66 & $\begin{array}{l}\text { MQTL- } \\
4 \mathrm{~B}-4\end{array}$ & 4B & 47.68 & 0.76 & $\begin{array}{l}47.30- \\
48.06\end{array}$ & 3 & $\begin{array}{l}\text { GW(1), } \\
\text { TN(1), } \\
\text { GN(1) }\end{array}$ & $\begin{array}{l}34.58- \\
52.99\end{array}$ & $\begin{array}{l}\text { Tdurum_contig10693_528- } \\
1210331\end{array}$ \\
\hline 67 & $\begin{array}{l}\text { MQTL- } \\
4 \mathrm{~B}-5\end{array}$ & $4 \mathrm{~B}$ & 51.63 & 0.88 & $\begin{array}{l}51.19- \\
52.07\end{array}$ & 19 & $\begin{array}{l}\text { GW(11), } \\
\text { GY(2), } \\
\text { TN(2), } \\
\text { GN(1), } \\
\text { SL(1), } \\
\text { SLN(1), } \\
\text { DTH(1) }\end{array}$ & $\begin{array}{l}414.71- \\
457.88\end{array}$ & $4536042-1059469$ \\
\hline 68 & $\begin{array}{l}\text { MQTL- } \\
\text { 4B-6 }\end{array}$ & 4B & 82.83 & 0.64 & $\begin{array}{l}82.51- \\
83.15\end{array}$ & 4 & $\begin{array}{l}\text { SL(2), } \\
\text { GW(1), } \\
G N(1)\end{array}$ & $\begin{array}{l}660.69- \\
667.89\end{array}$ & $1132850-1101163$ \\
\hline 69 & $\begin{array}{l}\text { MQTL- } \\
4 D-1\end{array}$ & 4D & 10.16 & 3.68 & $\begin{array}{l}8.32- \\
12.00\end{array}$ & 7 & $\begin{array}{l}\text { GW(3), } \\
\text { GFR(2), } \\
\text { GN(1), } \\
\text { GY(1) }\end{array}$ & $\begin{array}{l}6.02- \\
7.65\end{array}$ & $\begin{array}{l}\text { Kukri_rep_c106474_293- } \\
\text { Excalibur_c91022_193 }\end{array}$ \\
\hline
\end{tabular}




\begin{tabular}{|c|c|c|c|c|c|c|c|c|c|}
\hline No. & $\begin{array}{l}\text { MQTL } \\
\text { ID }\end{array}$ & $\mathrm{Chr}^{\mathrm{a}}$ & $\begin{array}{l}\text { Position } \\
(\mathrm{cM})^{\mathrm{b}}\end{array}$ & $\begin{array}{l}\mathrm{Cl} \\
(\mathrm{cM})^{\mathrm{c}}\end{array}$ & $\begin{array}{l}\text { Genetic } \\
\text { interval } \\
\text { (cM) }\end{array}$ & $\begin{array}{l}\text { No. } \\
\text { Of } \\
\text { QTLs }\end{array}$ & Traits $^{d}$ & $\begin{array}{l}\text { Physical } \\
\text { interval } \\
(\mathrm{Mb})\end{array}$ & Flanking markers \\
\hline 70 & $\begin{array}{l}\text { MQTL- } \\
4 D-2\end{array}$ & 4D & 30.24 & 1.29 & $\begin{array}{l}29.60- \\
30.89\end{array}$ & 26 & $\begin{array}{l}\text { GW(8), } \\
\text { GY(3), } \\
\text { SLN(3), } \\
\text { TN(3), } \\
\text { GN(2), } \\
\text { SL(2), } \\
\text { HI(2), } \\
\text { Others(2) }\end{array}$ & $\begin{array}{l}9.25- \\
12.41\end{array}$ & $1076436-1672793$ \\
\hline 71 & $\begin{array}{l}\text { MQTL- } \\
4 \mathrm{D}-3\end{array}$ & $4 \mathrm{D}$ & 39.08 & 4.88 & $\begin{array}{l}36.64- \\
41.52\end{array}$ & 2 & DTM(2) & $\begin{array}{l}16.10- \\
28.25\end{array}$ & $1266733-2245549$ \\
\hline 72 & $\begin{array}{l}\text { MQTL- } \\
4 \mathrm{D}-4\end{array}$ & $4 \mathrm{D}$ & 62.12 & 2.96 & $\begin{array}{l}60.64- \\
63.60\end{array}$ & 10 & $\begin{array}{l}\mathrm{GW}(4), \\
\mathrm{GN}(1), \\
\mathrm{TN}(1), \\
\mathrm{GY}(1), \\
\mathrm{SLN}(1), \\
\mathrm{BY}(1)\end{array}$ & $\begin{array}{l}304.69- \\
340.30\end{array}$ & 1099379-2257252 \\
\hline 73 & $\begin{array}{l}\text { MQTL- } \\
4 \mathrm{D}-5\end{array}$ & $4 \mathrm{D}$ & 83.31 & 1.59 & $\begin{array}{l}82.52- \\
84.11\end{array}$ & 6 & $\begin{array}{l}\text { GY(2), } \\
\text { GW(1), } \\
\text { TN(1), } \\
\text { GFR(1), } \\
\text { SLN(1) }\end{array}$ & $\begin{array}{l}490.61- \\
497.21\end{array}$ & $\begin{array}{l}\text { 1203384- } \\
\text { wsnp_RFL_Contig3893_4284191 }\end{array}$ \\
\hline 74 & $\begin{array}{l}\text { MQTL- } \\
5 A-1\end{array}$ & $5 \mathrm{~A}$ & 0 & 2.24 & $\begin{array}{l}0.00- \\
1.12\end{array}$ & 4 & $\begin{array}{l}\mathrm{TN}(2) \\
\mathrm{GW}(2)\end{array}$ & $\begin{array}{l}0.00- \\
2.85\end{array}$ & NA-4537943 \\
\hline 75 & $\begin{array}{l}\text { MQTL- } \\
5 A-2\end{array}$ & $5 A$ & 42.04 & 1.31 & $\begin{array}{l}41.39- \\
42.70\end{array}$ & 52 & $\begin{array}{l}\text { GW(22), } \\
\text { GY(6), } \\
\text { FD(6); } \\
\text { GN(3), } \\
\text { TN(3), } \\
\text { GFR(3) }\end{array}$ & $\begin{array}{l}488.26- \\
502.61\end{array}$ & CAP8_c1066_309-1000150 \\
\hline 76 & $\begin{array}{l}\text { MQTL- } \\
5 A-3\end{array}$ & $5 \mathrm{~A}$ & 51.31 & 1.29 & $\begin{array}{l}50.67- \\
51.96\end{array}$ & 57 & $\begin{array}{l}\text { GW(18), } \\
\text { GY(13), } \\
\text { GN(8), } \\
\text { SLN(5), } \\
\text { TN(4), } \\
\text { SL(4) }\end{array}$ & $\begin{array}{l}578.06- \\
592.64\end{array}$ & $\begin{array}{l}\text { BS00074299_51- } \\
\text { Excalibur_c31769_793 }\end{array}$ \\
\hline 77 & $\begin{array}{l}\text { MQTL- } \\
5 A-4\end{array}$ & $5 \mathrm{~A}$ & 63.78 & 1.76 & $\begin{array}{l}62.90- \\
64.66\end{array}$ & 18 & $\begin{array}{l}\text { GW(4), } \\
\text { TN(4), } \\
\text { GY(2), } \\
\text { SL(2), } \\
\text { SLN(2) }\end{array}$ & $\begin{array}{l}651.41- \\
659.22\end{array}$ & $1124903-3946991$ \\
\hline 78 & $\begin{array}{l}\text { MQTL- } \\
5 A-5\end{array}$ & $5 A$ & 77.15 & 2.68 & $\begin{array}{l}75.81- \\
78.49\end{array}$ & 13 & $\begin{array}{l}\mathrm{GW}(3), \\
\mathrm{GN}(3), \\
\text { others(3), } \\
\text { GY(1), } \\
\text { DHT(1) }\end{array}$ & $\begin{array}{l}684.94- \\
708.44\end{array}$ & $\begin{array}{l}\text { Tdurum_contig54689_646- } \\
\text { wsnp_Ex_c2171_4073472 }\end{array}$ \\
\hline 79 & $\begin{array}{l}\text { MQTL- } \\
5 A-6\end{array}$ & $5 \mathrm{~A}$ & 90.18 & 1.66 & $\begin{array}{l}89.35- \\
91.01\end{array}$ & 11 & $\begin{array}{l}\text { GW(4), } \\
\text { SLN(3), } \\
\text { others(3), } \\
\text { TN(1) }\end{array}$ & NA & Xabg391-Xabg366 \\
\hline 80 & $\begin{array}{l}\text { MQTL- } \\
5 A-7\end{array}$ & $5 \mathrm{~A}$ & 120.42 & 0.09 & $\begin{array}{l}120.38- \\
120.47\end{array}$ & 31 & $\begin{array}{l}\text { GW(8), } \\
\text { GN(5), } \\
\text { GY(4), } \\
\text { SLN(4), } \\
\text { TN(3) }\end{array}$ & $\begin{array}{l}667.93- \\
682.71\end{array}$ & Xwmc577-Xwmc524 \\
\hline
\end{tabular}




\begin{tabular}{|c|c|c|c|c|c|c|c|c|c|}
\hline No. & $\begin{array}{l}\text { MQTL } \\
\text { ID }\end{array}$ & $\mathrm{Chr}^{\mathrm{a}}$ & $\begin{array}{l}\text { Position } \\
(\mathrm{cM})^{\mathrm{b}}\end{array}$ & $\begin{array}{l}\mathrm{Cl} \\
(\mathrm{cM})^{\mathrm{c}}\end{array}$ & $\begin{array}{l}\text { Genetic } \\
\text { interval } \\
\text { (cM) }\end{array}$ & $\begin{array}{l}\text { No. } \\
\text { Of } \\
\text { QTLs }\end{array}$ & Traits $^{d}$ & $\begin{array}{l}\text { Physical } \\
\text { interval } \\
\text { (Mb) }\end{array}$ & Flanking markers \\
\hline 81 & $\begin{array}{l}\text { MQTL- } \\
5 B-1\end{array}$ & $5 B$ & 9.73 & 1.98 & $\begin{array}{l}8.74- \\
10.72\end{array}$ & 22 & $\begin{array}{l}\text { GW(9), } \\
\text { GY(7), } \\
\text { TN(2), } \\
\text { GN(2), } \\
\text { SL(1), } \\
\text { FD(1) }\end{array}$ & $\begin{array}{l}15.29- \\
51.97\end{array}$ & $1088238-1117203$ \\
\hline 82 & $\begin{array}{l}\text { MQTL- } \\
5 \mathrm{~B}-2\end{array}$ & $5 B$ & 20.78 & 4.1 & $\begin{array}{l}18.73- \\
22.83\end{array}$ & 4 & $\begin{array}{l}\mathrm{GW}(2), \\
\mathrm{GN}(1), \\
\text { others(1) }\end{array}$ & $\begin{array}{l}507.86- \\
519.03\end{array}$ & $1159437-4405411$ \\
\hline 83 & $\begin{array}{l}\text { MQTL- } \\
\text { 5B-3 }\end{array}$ & $5 B$ & 39.66 & 3.17 & $\begin{array}{l}38.08- \\
41.25\end{array}$ & 11 & $\begin{array}{l}\text { GW(3), } \\
\text { GY(2), } \\
\text { GN(2), } \\
\text { GFR(1), } \\
\text { Others(1), } \\
\text { DTM(1), } \\
\text { FD(1) }\end{array}$ & $\begin{array}{l}590.40- \\
604.06\end{array}$ & $\begin{array}{l}\text { 1083434- } \\
\text { Tdurum_contig70123_354 }\end{array}$ \\
\hline 84 & $\begin{array}{l}\text { MQTL- } \\
\text { 5B-4 }\end{array}$ & $5 B$ & 54.59 & 3.71 & $\begin{array}{l}52.74- \\
56.45\end{array}$ & 3 & $\begin{array}{l}\mathrm{HI}(2) \\
\mathrm{GW}(1)\end{array}$ & $\begin{array}{l}662.03- \\
671.71\end{array}$ & $\begin{array}{l}\text { Tdurum_contig45588_304- } \\
1083023\end{array}$ \\
\hline 85 & $\begin{array}{l}\text { MQTL- } \\
5 B-5\end{array}$ & $5 B$ & 59.71 & 5.42 & $\begin{array}{l}57.00- \\
62.42\end{array}$ & 27 & $\begin{array}{l}\text { GW(12), } \\
\text { TN(4), } \\
\text { GN(4), } \\
\text { GY(2), } \\
\text { SLN(2) }\end{array}$ & $\begin{array}{l}668.83- \\
678.34\end{array}$ & $\begin{array}{l}\text { 1862793-- } \\
\text { wsnp_BE403710B_Ta_2_1 }\end{array}$ \\
\hline 86 & $\begin{array}{l}\text { MQTL- } \\
5 \mathrm{~B}-6\end{array}$ & $5 B$ & 65.17 & 5.55 & $\begin{array}{l}62.40- \\
67.95\end{array}$ & 13 & $\begin{array}{l}\text { GW(4), } \\
\text { TN(4), } \\
\text { GN(1), } \\
\text { GFR(1), } \\
\text { BY(1), } \\
\text { DTH(1), } \\
\text { Others(1) }\end{array}$ & $\begin{array}{l}679.35- \\
692.63\end{array}$ & $\begin{array}{l}\text { wsnp_Ra_c19660_28866961- } \\
\text { Kukri_c1214_948 }\end{array}$ \\
\hline 87 & $\begin{array}{l}\text { MQTL- } \\
\text { 5B-7 }\end{array}$ & $5 B$ & 77.66 & 6.03 & $\begin{array}{l}74.65- \\
80.68\end{array}$ & 4 & $\begin{array}{l}\text { GW(2), } \\
\text { TN(1), } \\
\text { GN(1) }\end{array}$ & $\begin{array}{l}704.95- \\
712.41\end{array}$ & $1114164-1048115$ \\
\hline 88 & $\begin{array}{l}\text { MQTL- } \\
5 B-8\end{array}$ & $5 B$ & 93.08 & 5.67 & $\begin{array}{l}90.25- \\
95.92\end{array}$ & 3 & $\begin{array}{l}\mathrm{GW}(2) \\
\mathrm{GY}(1)\end{array}$ & NA & Xgwm777-Xfba332.1 \\
\hline 89 & $\begin{array}{l}\text { MQTL- } \\
5 B-9\end{array}$ & $5 B$ & 128.96 & 1.13 & $\begin{array}{l}128.40- \\
129.53\end{array}$ & 14 & $\begin{array}{l}\text { GW(5), } \\
\text { HI(3), } \\
\text { SLN(2), } \\
\text { others(2), } \\
\text { GN(1), } \\
\text { DTH(1) }\end{array}$ & $\begin{array}{l}604.80- \\
612.87\end{array}$ & Xwmc99-Xwmc734 \\
\hline 90 & $\begin{array}{l}\text { MQTL- } \\
\text { 5D-1 }\end{array}$ & $5 \mathrm{D}$ & 0.32 & 1.72 & $\begin{array}{l}0.00- \\
1.18\end{array}$ & 4 & $\begin{array}{l}\text { GW(2), } \\
\text { TN(1)' } \\
\text { DTH(1) }\end{array}$ & 3.59 & $\mathrm{Ha}$ \\
\hline 91 & $\begin{array}{l}\text { MQTL- } \\
5 \mathrm{D}-2\end{array}$ & $5 \mathrm{D}$ & 15.59 & 7.23 & $\begin{array}{l}11.98- \\
19.21\end{array}$ & 2 & $S L(2)$ & $\begin{array}{l}0.94- \\
99.92\end{array}$ & Xgpw326-Xwmc150 \\
\hline 92 & $\begin{array}{l}\text { MQTL- } \\
5 D-3\end{array}$ & $5 \mathrm{D}$ & 23.91 & 4.79 & $\begin{array}{l}21.52- \\
26.31\end{array}$ & 7 & $\begin{array}{l}\text { TN(2), } \\
\text { GN(1), } \\
\text { GFR(1), } \\
\text { SLN(1), } \\
\text { DTH(1), } \\
\text { Others(1) }\end{array}$ & $\begin{array}{l}44.57- \\
54.72\end{array}$ & Xwmc434a-Xcfd81 \\
\hline
\end{tabular}




\begin{tabular}{|c|c|c|c|c|c|c|c|c|c|}
\hline No. & $\begin{array}{l}\text { MQTL } \\
\text { ID }\end{array}$ & $\mathrm{Chr}^{\mathrm{a}}$ & $\begin{array}{l}\text { Position } \\
(\mathrm{cM})^{\mathrm{b}}\end{array}$ & $\begin{array}{l}\mathrm{Cl} \\
(\mathrm{cM})^{\mathrm{c}}\end{array}$ & $\begin{array}{l}\text { Genetic } \\
\text { interval } \\
\text { (cM) }\end{array}$ & $\begin{array}{l}\text { No. } \\
\text { Of } \\
\text { QTLs }\end{array}$ & Traits $^{d}$ & $\begin{array}{l}\text { Physical } \\
\text { interval } \\
\text { (Mb) }\end{array}$ & Flanking markers \\
\hline 93 & $\begin{array}{l}\text { MQTL- } \\
5 \mathrm{D}-4\end{array}$ & $5 \mathrm{D}$ & 46.72 & 3.53 & $\begin{array}{l}44.96- \\
48.49\end{array}$ & 15 & $\begin{array}{l}\text { SL(5), } \\
\text { GW(4), } \\
\text { others(2), } \\
\text { GN(1), } \\
\text { GFR(1), } \\
\text { SLN(1), } \\
\text { BY(1) }\end{array}$ & $\begin{array}{l}398.77- \\
420.92\end{array}$ & $\begin{array}{l}\text { BobWhite_c10764_251- } \\
\text { wsnp_JD_c3690_4731341 }\end{array}$ \\
\hline 94 & $\begin{array}{l}\text { MQTL- } \\
5 D-5\end{array}$ & $5 \mathrm{D}$ & 63.98 & 2.98 & $\begin{array}{l}62.49- \\
65.47\end{array}$ & 10 & $\begin{array}{l}\text { TN(4), } \\
\text { SLN(3), } \\
\text { GN(2), } \\
\text { GW(1) }\end{array}$ & $\begin{array}{l}48.67- \\
80.31\end{array}$ & $1671199-2256293$ \\
\hline 95 & $\begin{array}{l}\text { MQTL- } \\
5 D-6\end{array}$ & $5 \mathrm{D}$ & 71.48 & 3.22 & $\begin{array}{l}69.87- \\
73.09\end{array}$ & 7 & $\begin{array}{l}\text { TN(3), } \\
\text { GY(2), } \\
\text { FD(1), } \\
\text { GN(1) }\end{array}$ & $\begin{array}{l}337.31- \\
345.18\end{array}$ & $3222415-1207257$ \\
\hline 96 & $\begin{array}{l}\text { MQTL- } \\
5 \mathrm{D}-7\end{array}$ & $5 \mathrm{D}$ & 95.69 & 3.34 & $\begin{array}{l}94.02- \\
97.36\end{array}$ & 8 & $\begin{array}{l}\text { SL(2), } \\
\text { TN(2), } \\
\text { GN(1), } \\
\text { SLN(1), } \\
\text { DTH(1), } \\
\text { DTM(1) }\end{array}$ & $\begin{array}{l}435.59- \\
442.50\end{array}$ & $1670863-1126619$ \\
\hline 97 & $\begin{array}{l}\text { MQTL- } \\
5 D-8\end{array}$ & $5 \mathrm{D}$ & 121.09 & 0.13 & $\begin{array}{l}121.03- \\
121.16\end{array}$ & 3 & $\begin{array}{l}\text { SLN(2), } \\
\operatorname{DTH}(1)\end{array}$ & $\begin{array}{l}487.30- \\
498.40\end{array}$ & $\begin{array}{l}\text { D_GDEEGVY01D91EB_346- } \\
2245814\end{array}$ \\
\hline 98 & $\begin{array}{l}\text { MQTL- } \\
6 A-1\end{array}$ & $6 \mathrm{~A}$ & 6.15 & 4.74 & $\begin{array}{l}3.78- \\
8.52\end{array}$ & 5 & $\begin{array}{l}\text { GW(1), } \\
\text { GY(1), } \\
\text { GN(1), } \\
\text { SLN(1), } \\
\text { others(1) }\end{array}$ & $\begin{array}{l}0.29- \\
6.73\end{array}$ & $\begin{array}{l}\text { wsnp_Ex_rep_c68915_67808523- } \\
\text { Excalibur_c20597_509 }\end{array}$ \\
\hline 99 & $\begin{array}{l}\text { MQTL- } \\
6 \mathrm{~A}-2\end{array}$ & $6 \mathrm{~A}$ & 28.81 & 3.63 & $\begin{array}{l}27.00- \\
30.63\end{array}$ & 28 & $\begin{array}{l}\text { GW(9), } \\
\text { GY(4), } \\
\text { TN(4), } \\
\text { GN(3), } \\
\text { SLN(3) }\end{array}$ & $\begin{array}{l}38.77- \\
52.21\end{array}$ & $1074651-1107337$ \\
\hline 100 & $\begin{array}{l}\text { MQTL- } \\
6 A-3\end{array}$ & $6 \mathrm{~A}$ & 40.96 & 7.37 & $\begin{array}{l}37.28- \\
44.65\end{array}$ & 3 & $\begin{array}{l}\mathrm{GW}(2) \\
\operatorname{SLN}(1)\end{array}$ & $\begin{array}{l}58.15- \\
85.83\end{array}$ & $\begin{array}{l}\text { 4017666-- } \\
\text { wsnp_Ex_c14692_22766127 }\end{array}$ \\
\hline 101 & $\begin{array}{l}\text { MQTL- } \\
6 A-4\end{array}$ & $6 \mathrm{~A}$ & 49.75 & 3.42 & $\begin{array}{l}48.04- \\
51.46\end{array}$ & 16 & $\begin{array}{l}\text { GW(7), } \\
\text { GY(2), } \\
\text { TN(2), } \\
\text { DTH(2), } \\
\text { GN(1), } \\
\text { FD(1), } \\
\text { Others(1) }\end{array}$ & $\begin{array}{l}518.78- \\
538.41\end{array}$ & 979315-1094026 \\
\hline 102 & $\begin{array}{l}\text { MQTL- } \\
6 A-5\end{array}$ & $6 A$ & 56.62 & 5.71 & $\begin{array}{l}53.77- \\
59.48\end{array}$ & 28 & $\begin{array}{l}\text { GW(15), } \\
\text { GY(4), } \\
\text { TN(2); } \\
\text { GN(2), } \\
\text { SL(2) }\end{array}$ & $\begin{array}{l}559.43- \\
569.12\end{array}$ & 1087752-Kukri_rep_c69713_250 \\
\hline 103 & $\begin{array}{l}\text { MQTL- } \\
6 A-6\end{array}$ & $6 \mathrm{~A}$ & 68.43 & 4.47 & $\begin{array}{l}66.20- \\
70.67\end{array}$ & 9 & $\begin{array}{l}\text { GW(4), } \\
\text { TN(2), } \\
\text { SLN(2), } \\
\text { GN(1) }\end{array}$ & $\begin{array}{l}581.74- \\
590.10\end{array}$ & BobWhite_c14304_687-1046343 \\
\hline 104 & $\begin{array}{l}\text { MQTL- } \\
6 A-7\end{array}$ & $6 \mathrm{~A}$ & 80.4 & 3.48 & $\begin{array}{l}78.66- \\
82.14\end{array}$ & 7 & $\begin{array}{l}\text { GW(5), } \\
\text { GN(1), } \\
\text { SL(1) }\end{array}$ & $\begin{array}{l}595.00- \\
602.91\end{array}$ & $1065154-1004240$ \\
\hline
\end{tabular}




\begin{tabular}{|c|c|c|c|c|c|c|c|c|c|}
\hline No. & $\begin{array}{l}\text { MQTL } \\
\text { ID }\end{array}$ & $\mathrm{Chr}^{\mathrm{a}}$ & $\begin{array}{l}\text { Position } \\
(\mathrm{cM})^{\mathrm{b}}\end{array}$ & $\begin{array}{l}\mathrm{Cl} \\
(\mathrm{cM})^{\mathrm{c}}\end{array}$ & $\begin{array}{l}\text { Genetic } \\
\text { interval } \\
\text { (cM) }\end{array}$ & $\begin{array}{l}\text { No. } \\
\text { Of } \\
\text { QTLs }\end{array}$ & Traits $^{d}$ & $\begin{array}{l}\text { Physical } \\
\text { interval } \\
\text { (Mb) }\end{array}$ & Flanking markers \\
\hline 105 & $\begin{array}{l}\text { MQTL- } \\
6 A-8\end{array}$ & $6 \mathrm{~A}$ & 107.44 & 1.36 & $\begin{array}{l}106.76- \\
108.12\end{array}$ & 8 & $\begin{array}{l}\text { GW(3), } \\
\text { GN(2), } \\
\text { TN(1), } \\
\text { GY(1), } \\
\text { SL(1) }\end{array}$ & $\begin{array}{l}606.59- \\
615.06\end{array}$ & 1011228-Xwmc580 \\
\hline 106 & $\begin{array}{l}\text { MQTL- } \\
6 \mathrm{~B}-1\end{array}$ & $6 B$ & 5.05 & 5.3 & $\begin{array}{l}2.40- \\
7.70\end{array}$ & 8 & $\begin{array}{l}\text { GY(2), } \\
\text { GN(2), } \\
\text { GW(1), } \\
\text { SL(1), } \\
\text { DTH(1), } \\
\text { Others(1) }\end{array}$ & $\begin{array}{l}10.06- \\
24.89\end{array}$ & wPt-5234-1035961 \\
\hline 107 & $\begin{array}{l}\text { MQTL- } \\
6 \mathrm{~B}-2\end{array}$ & $6 \mathrm{~B}$ & 30.9 & 4.34 & $\begin{array}{l}28.73- \\
33.07\end{array}$ & 5 & $\begin{array}{l}\text { GW(3), } \\
\text { SL(1), } \\
\text { SLN(1) }\end{array}$ & $\begin{array}{l}28.12- \\
42.39\end{array}$ & $\begin{array}{l}\text { BS00027942_51- } \\
\text { wsnp_Ex_c40044_47184747 }\end{array}$ \\
\hline 108 & $\begin{array}{l}\text { MQTL- } \\
6 \mathrm{~B}-3\end{array}$ & $6 \mathrm{~B}$ & 40.57 & 2.6 & $\begin{array}{l}39.27- \\
41.87\end{array}$ & 19 & $\begin{array}{l}\text { GW(10), } \\
\text { GY(2), } \\
\text { GN(2), } \\
\text { TN(1), } \\
\text { SLN(1), } \\
\text { HI(1), } \\
\text { FD(1), } \\
\text { Others(1) }\end{array}$ & $\begin{array}{l}153.36- \\
201.41\end{array}$ & $3955832-1212043$ \\
\hline 109 & $\begin{array}{l}\text { MQTL- } \\
6 \mathrm{~B}-4\end{array}$ & $6 B$ & 51.44 & 2.14 & $\begin{array}{l}50.37- \\
52.51\end{array}$ & 28 & $\begin{array}{l}\text { GW(9), } \\
\text { GY(4), } \\
\text { GN(4), } \\
\text { FD(4), } \\
\text { SL(2)', } \\
\text { DTH(2) }\end{array}$ & $\begin{array}{l}661.34- \\
674.16\end{array}$ & $\begin{array}{l}\text { wsnp_CAP12_c475_258416- } \\
1131676\end{array}$ \\
\hline 110 & $\begin{array}{l}\text { MQTL- } \\
6 \mathrm{~B}-5\end{array}$ & $6 \mathrm{~B}$ & 66.49 & 8.61 & $\begin{array}{l}62.19- \\
70.80\end{array}$ & 6 & GW(6) & $\begin{array}{l}\text { 693.82- } \\
712.17\end{array}$ & 1233630-wPt-9660 \\
\hline 111 & $\begin{array}{l}\text { MQTL- } \\
6 \mathrm{~B}-6\end{array}$ & $6 B$ & 76.79 & 0.24 & $\begin{array}{l}76.67- \\
76.91\end{array}$ & 11 & $\begin{array}{l}\text { GW(4), } \\
\text { GN(4), } \\
\text { SL(2), } \\
\text { Others(1) }\end{array}$ & $\begin{array}{l}\text { 704.56- } \\
708.03\end{array}$ & 1205602-tplb0046e21_221 \\
\hline 112 & $\begin{array}{l}\text { MQTL- } \\
6 \mathrm{D}-1\end{array}$ & $6 \mathrm{D}$ & 14.86 & 2.28 & $\begin{array}{l}13.72- \\
16.00\end{array}$ & 3 & $\begin{array}{l}\text { GW(1), } \\
\text { GY(1), } \\
\text { GN(1) }\end{array}$ & $\begin{array}{l}2.41- \\
7.10\end{array}$ & $\begin{array}{l}\text { wsnp_Ex_c14439_22426200- } \\
\text { BobWhite_c11808_975 }\end{array}$ \\
\hline 113 & $\begin{array}{l}\text { MQTL- } \\
6 \mathrm{D}-2\end{array}$ & $6 \mathrm{D}$ & 37.21 & 3.87 & $\begin{array}{l}35.28- \\
39.15\end{array}$ & 12 & $\begin{array}{l}\text { GY(5), } \\
\text { GW(3), } \\
\text { GFR(2), } \\
\text { TN(1), } \\
\text { FD(1) }\end{array}$ & $\begin{array}{l}16.20- \\
20.79\end{array}$ & $2249020-1103799$ \\
\hline 114 & $\begin{array}{l}\text { MQTL- } \\
6 \mathrm{D}-3\end{array}$ & $6 \mathrm{D}$ & 64.56 & 2.49 & $\begin{array}{l}63.32- \\
65.81\end{array}$ & 15 & $\begin{array}{l}\text { GN(5), } \\
\text { GY(3), } \\
\text { GW(2), } \\
\text { TN(2), } \\
\text { GFR(2) }\end{array}$ & $\begin{array}{l}445.97- \\
451.02\end{array}$ & $2256054-1217709$ \\
\hline 115 & $\underset{6 D-4}{M Q T L-}$ & $6 \mathrm{D}$ & 70.17 & 4.87 & $\begin{array}{l}67.74- \\
72.61\end{array}$ & 4 & $\begin{array}{l}\text { GN(1), } \\
\text { GW(1), } \\
\text { TN(1), } \\
\text { SLN(1) }\end{array}$ & $\begin{array}{l}455.46- \\
463.71\end{array}$ & 1239335-wPt-734218 \\
\hline 116 & $\begin{array}{l}\text { MQTL- } \\
6 \mathrm{D}-5\end{array}$ & $6 \mathrm{D}$ & 84.13 & 9.54 & $\begin{array}{l}79.36- \\
88.90\end{array}$ & 2 & $\begin{array}{l}\text { GY(1), } \\
\text { others(1) }\end{array}$ & $\begin{array}{l}326.98- \\
470.64\end{array}$ & Xcfd287-Excalibur_c7546_1286 \\
\hline
\end{tabular}




\begin{tabular}{|c|c|c|c|c|c|c|c|c|c|}
\hline No. & $\begin{array}{l}\text { MQTL } \\
\text { ID }\end{array}$ & $\mathrm{Chr}^{\mathrm{a}}$ & $\begin{array}{l}\text { Position } \\
(\mathrm{cM})^{\mathrm{b}}\end{array}$ & $\begin{array}{l}\mathrm{Cl} \\
(\mathrm{cM})^{\mathrm{c}}\end{array}$ & $\begin{array}{l}\text { Genetic } \\
\text { interval } \\
\text { (cM) }\end{array}$ & $\begin{array}{l}\text { No. } \\
\text { Of } \\
\text { QTLs }\end{array}$ & Traits $^{d}$ & $\begin{array}{l}\text { Physical } \\
\text { interval } \\
\text { (Mb) }\end{array}$ & Flanking markers \\
\hline 117 & $\begin{array}{l}\text { MQTL- } \\
\text { 6D-6 }\end{array}$ & 6D & 105.92 & 4.24 & $\begin{array}{l}103.80- \\
108.04\end{array}$ & 6 & $\begin{array}{l}\text { SLN(2), } \\
\text { GW(1), } \\
\text { TN(1), } \\
\text { GY(1), } \\
\text { BY(1) }\end{array}$ & $\begin{array}{l}465.21- \\
472.40\end{array}$ & BS00087334_51-1256004 \\
\hline 118 & $\begin{array}{l}\text { MQTL- } \\
6 \mathrm{D}-7\end{array}$ & $6 \mathrm{D}$ & 114.41 & 3.94 & $\begin{array}{l}112.44- \\
116.38\end{array}$ & 4 & $\begin{array}{l}\text { GY(2), } \\
\text { GW(1), } \\
\text { others(1) }\end{array}$ & $\begin{array}{l}469.54- \\
472.93\end{array}$ & $1252653-3028753$ \\
\hline 119 & $\begin{array}{l}\text { MQTL- } \\
6 \mathrm{D}-8\end{array}$ & $6 \mathrm{D}$ & 203 & 8.26 & $\begin{array}{l}198.87- \\
207.13\end{array}$ & 2 & $\mathrm{GY}(2)$ & NA & P40/M47-5-Xgdm98-6D \\
\hline 120 & $\begin{array}{l}\text { MQTL- } \\
\text { 7A-1 }\end{array}$ & $7 \mathrm{~A}$ & 17.69 & 2.83 & $\begin{array}{l}16.28- \\
19.11\end{array}$ & 8 & $\begin{array}{l}\text { BY(2), } \\
\text { GN(1), } \\
\text { GY(1), } \\
\text { SL(1), } \\
\text { SLN(1), } \\
\text { HI(1), } \\
\text { Others(1) }\end{array}$ & $\begin{array}{l}5.20- \\
21.80\end{array}$ & Kukri_c11770_148-Xwmc479 \\
\hline 121 & $\begin{array}{l}\text { MQTL- } \\
7 A-2\end{array}$ & $7 A$ & 37.87 & 2.37 & $\begin{array}{l}36.69- \\
39.06\end{array}$ & 16 & $\begin{array}{l}\text { SLN(4), } \\
\text { FD(3), } \\
\text { DTH(2), } \\
\text { TN(2), } \\
\text { GW(1), } \\
\text { GY(1), } \\
\text { SL(1)', } \\
\text { DTM(1), } \\
\text { Others(1) }\end{array}$ & $\begin{array}{l}18.88- \\
24.59\end{array}$ & $\begin{array}{l}\text { wsnp_Ku_c3969_7256560- } \\
\text { wsnp_Ex_c30239_39179460 }\end{array}$ \\
\hline 122 & $\begin{array}{l}\text { MQTL- } \\
7 A-3\end{array}$ & $7 \mathrm{~A}$ & 61.77 & 2.1 & $\begin{array}{l}60.72- \\
62.82\end{array}$ & 24 & $\begin{array}{l}\text { GW(8), } \\
\text { GN(5), } \\
\text { GY(3), } \\
\text { TN(3), } \\
\text { DTM(2) }\end{array}$ & $\begin{array}{l}54.84- \\
68.09\end{array}$ & 4003949-GENE-4632_640 \\
\hline 123 & $\begin{array}{l}\text { MQTL- } \\
7 A-4\end{array}$ & $7 A$ & 73.2 & 2.08 & $\begin{array}{l}72.16- \\
74.24\end{array}$ & 18 & $\begin{array}{l}\text { GW(6), } \\
\text { GY(6), } \\
\text { GN(4), } \\
\text { SL(1), } \\
\text { BY(1) }\end{array}$ & $\begin{array}{l}77.44- \\
79.78\end{array}$ & BS00091891_51-GENE-4375_382 \\
\hline 124 & $\begin{array}{l}\text { MQTL- } \\
7 A-5\end{array}$ & $7 A$ & 86.3 & 2.94 & $\begin{array}{l}84.83- \\
87.77\end{array}$ & 20 & $\begin{array}{l}\text { GN(5), } \\
\text { GW(4), } \\
\text { GY(4), } \\
\text { TN(2), } \\
\text { DTH(2) }\end{array}$ & $\begin{array}{l}108.82- \\
616.55\end{array}$ & $\begin{array}{l}\text { wsnp_Ex_c5341_9443380- } \\
3956375\end{array}$ \\
\hline 125 & $\begin{array}{l}\text { MQTL- } \\
7 A-6\end{array}$ & 7A & 100.14 & 1.63 & $\begin{array}{l}99.33- \\
100.96\end{array}$ & 29 & $\begin{array}{l}\text { GW(15), } \\
\text { GN(7), } \\
\text { GY(2); } \\
\text { TN(2); } \\
\text { GY(1); } \\
\text { SLN(1), } \\
\text { BY(1) }\end{array}$ & $\begin{array}{l}675.27- \\
688.69\end{array}$ & $1115464-5581759$ \\
\hline 126 & $\begin{array}{l}\text { MQTL- } \\
7 A-7\end{array}$ & $7 A$ & 116.85 & 3.23 & $\begin{array}{l}115.24- \\
118.47\end{array}$ & 10 & $\begin{array}{l}\text { GW(5), } \\
\text { HI(2), } \\
\text { GN(1), } \\
\text { GY(1), } \\
\text { Others(1) }\end{array}$ & $\begin{array}{l}694.36- \\
703.56\end{array}$ & 1150384-Excalibur_c20018_214 \\
\hline 127 & $\begin{array}{l}\text { MQTL- } \\
7 A-8\end{array}$ & $7 \mathrm{~A}$ & 135.09 & 0.78 & $\begin{array}{l}134.70- \\
135.48\end{array}$ & 5 & $\begin{array}{l}\mathrm{GW}(3), \\
\mathrm{GN}(1), \\
\text { others(1) }\end{array}$ & $\begin{array}{l}726.48- \\
730.43\end{array}$ & $\begin{array}{l}\text { wsnp_BF483039A_Ta_2_1- } \\
\text { wsnp_JD_c19925_17854742 }\end{array}$ \\
\hline
\end{tabular}




\begin{tabular}{|c|c|c|c|c|c|c|c|c|c|}
\hline No. & $\begin{array}{l}\text { MQTL } \\
\text { ID }\end{array}$ & $\mathrm{Chr}^{\mathrm{a}}$ & $\begin{array}{l}\text { Position } \\
(\mathrm{cM})^{\mathrm{b}}\end{array}$ & $\begin{array}{l}\mathrm{Cl} \\
(\mathrm{cM})^{\mathrm{c}}\end{array}$ & $\begin{array}{l}\text { Genetic } \\
\text { interval } \\
\text { (cM) }\end{array}$ & $\begin{array}{l}\text { No. } \\
\text { Of } \\
\text { QTLs }\end{array}$ & Traits $^{d}$ & $\begin{array}{l}\text { Physical } \\
\text { interval } \\
\text { (Mb) }\end{array}$ & Flanking markers \\
\hline 128 & $\begin{array}{l}\text { MQTL- } \\
\text { 7B-1 }\end{array}$ & 7B & 6.45 & 4.58 & $\begin{array}{l}4.16- \\
8.74\end{array}$ & 3 & $\begin{array}{l}\text { SL(2), } \\
\text { GY(1) }\end{array}$ & $\begin{array}{l}1.03- \\
6.23\end{array}$ & Excalibur_c3489_182-1280023 \\
\hline 129 & $\begin{array}{l}\text { MQTL- } \\
\text { 7B-2 }\end{array}$ & 7B & 28.48 & 4.22 & $\begin{array}{l}26.37- \\
30.59\end{array}$ & 14 & $\begin{array}{l}\text { GW(6), } \\
\text { GN(3), } \\
\text { GY(2), } \\
\text { SLN(1), } \\
\text { DTH(1), } \\
\text { FD(1) }\end{array}$ & $\begin{array}{l}11.96- \\
24.06\end{array}$ & $\begin{array}{l}\text { BS00081132_51- } \\
\text { Kukri_c109962_396 }\end{array}$ \\
\hline 130 & $\begin{array}{l}\text { MQTL- } \\
\text { 7B-3 }\end{array}$ & 7B & 44.61 & 4.51 & $\begin{array}{l}42.36- \\
46.87\end{array}$ & 5 & $\begin{array}{l}\mathrm{GW}(2) \\
\mathrm{GN}(1), \\
\mathrm{SL}(1) \\
\mathrm{SLN}(1)\end{array}$ & $\begin{array}{l}64.42- \\
104.56\end{array}$ & $1216942-2254984$ \\
\hline 131 & $\begin{array}{l}\text { MQTL- } \\
\text { 7B-4 }\end{array}$ & 7B & 63.45 & 2.67 & $\begin{array}{l}62.12- \\
64.79\end{array}$ & 14 & $\begin{array}{l}\text { GW(9), } \\
\text { TN(2), } \\
\text { GN(1), } \\
\text { DTH(1), } \\
\text { Others(1) }\end{array}$ & $\begin{array}{l}639.36- \\
654.93\end{array}$ & $\begin{array}{l}\text { Kukri_c35918_164- } \\
\text { Kukri_rep_c103094_177 }\end{array}$ \\
\hline 132 & $\begin{array}{l}\text { MQTL- } \\
\text { 7B-5 }\end{array}$ & 7B & 69.28 & 2.38 & $\begin{array}{l}68.09- \\
70.47\end{array}$ & 16 & $\begin{array}{l}\text { GN(6), } \\
\text { GW(5), } \\
\text { DTH(2), } \\
\text { SL(1), } \\
\text { SLN(1), } \\
\text { Others(1) }\end{array}$ & $\begin{array}{l}665.52- \\
672.55\end{array}$ & $2255911-2279429$ \\
\hline 133 & $\begin{array}{l}\text { MQTL- } \\
7 \mathrm{~B}-6\end{array}$ & 7B & 89.33 & 4.34 & $\begin{array}{l}87.16- \\
91.50\end{array}$ & 5 & $\begin{array}{l}\text { GW(3), } \\
\text { GFR(1), } \\
\text { DTM(1) }\end{array}$ & $\begin{array}{l}697.54- \\
707.72\end{array}$ & $1051812-1112823$ \\
\hline 134 & $\begin{array}{l}\text { MQTL- } \\
\text { 7B-7 }\end{array}$ & 7B & 100.38 & 5.68 & $\begin{array}{l}97.54- \\
103.22\end{array}$ & 3 & $\begin{array}{l}\text { SL(2), } \\
\operatorname{TN}(1)\end{array}$ & $\begin{array}{l}\text { 717.79- } \\
732.15\end{array}$ & $\begin{array}{l}\text { Tdurum_contig44457_1064- } \\
\text { Kukri_c40149_436 }\end{array}$ \\
\hline 135 & $\begin{array}{l}\text { MQTL- } \\
\text { 7B-8 }\end{array}$ & 7B & 112.84 & 7.02 & $\begin{array}{l}109.33- \\
116.35\end{array}$ & 6 & $\begin{array}{l}\text { SL(2), } \\
\text { SLN(2), } \\
\text { GN(1), } \\
\text { GW(1) }\end{array}$ & $\begin{array}{l}743.45- \\
749.30\end{array}$ & $1122207-1300047$ \\
\hline 136 & $\begin{array}{l}\text { MQTL- } \\
\text { 7B-9 }\end{array}$ & 7B & 136.91 & 0.25 & $\begin{array}{l}136.79- \\
137.04\end{array}$ & 10 & $\begin{array}{l}\text { GW(6), } \\
\text { TN(2), } \\
\text { GN(1), } \\
\text { SLN(1) }\end{array}$ & 705.26 & Xwmc613 \\
\hline 137 & $\begin{array}{l}\text { MQTL- } \\
\text { 7D-1 }\end{array}$ & 7D & 25.56 & 4.88 & $\begin{array}{l}23.12- \\
28.00\end{array}$ & 15 & $\begin{array}{l}\text { GY(4), } \\
\text { GN(2), } \\
\text { GW(2), } \\
\text { DTH(2), } \\
\text { TN(2), } \\
\text { SLN(2) }\end{array}$ & $\begin{array}{l}6.48- \\
14.19\end{array}$ & Kukri_c45368_300-995933 \\
\hline 138 & $\begin{array}{l}\text { MQTL- } \\
\text { 7D-2 }\end{array}$ & $7 D$ & 45.76 & 5.14 & $\begin{array}{l}43.19- \\
48.33\end{array}$ & 5 & $\begin{array}{l}\operatorname{SLN}(2), \\
\text { BY(1), } \\
\text { GW(1), } \\
\text { HI(1) }\end{array}$ & $\begin{array}{l}585.90- \\
598.52\end{array}$ & 1213315-995258 \\
\hline 139 & $\begin{array}{l}\text { MQTL- } \\
7 D-3\end{array}$ & $7 D$ & 69.74 & 3.53 & $\begin{array}{l}67.98- \\
71.51\end{array}$ & 4 & $\begin{array}{l}\text { GW(2), } \\
\text { DTM(1), } \\
\text { TN(1) }\end{array}$ & $\begin{array}{l}527.58- \\
615.21\end{array}$ & 1061150-Xbarc214 \\
\hline 140 & $\begin{array}{l}\text { MQTL- } \\
\text { 7D-4 }\end{array}$ & $7 D$ & 76.83 & 3.62 & $\begin{array}{l}75.02- \\
78.64\end{array}$ & 8 & $\begin{array}{l}\text { GW(2), } \\
\text { SL(2), } \\
\text { DTH(1), } \\
\text { DTM(1), } \\
\text { SLN(1) }\end{array}$ & $\begin{array}{l}474.89- \\
506.74\end{array}$ & Xbarc125-Xwmc702 \\
\hline
\end{tabular}




\begin{tabular}{|c|c|c|c|c|c|c|c|c|c|}
\hline No. & $\begin{array}{l}\text { MQTL } \\
\text { ID }\end{array}$ & Chr. $^{a}$ & $\begin{array}{l}\text { Position } \\
(\mathrm{cM})^{\mathrm{b}}\end{array}$ & $\begin{array}{l}\mathrm{Cl} \\
(\mathrm{cM})^{\mathrm{c}}\end{array}$ & $\begin{array}{l}\text { Genetic } \\
\text { interval } \\
\text { (cM) }\end{array}$ & $\begin{array}{l}\text { No. } \\
\text { Of } \\
\text { QTLs }\end{array}$ & Traits $^{d}$ & $\begin{array}{l}\text { Physical } \\
\text { interval } \\
\text { (Mb) }\end{array}$ & Flanking markers \\
\hline 141 & $\begin{array}{l}\text { MQTL- } \\
7 D-5\end{array}$ & $7 D$ & 88.29 & 3.28 & $\begin{array}{l}86.65- \\
89.93\end{array}$ & 3 & $\begin{array}{l}\mathrm{GN}(1) \\
\mathrm{GW}(1) \\
\mathrm{SLN}(1)\end{array}$ & $\begin{array}{l}132.20- \\
174.80\end{array}$ & Xwmc121-Xcfd68 \\
\hline 142 & $\begin{array}{l}\text { MQTL- } \\
7 D-6\end{array}$ & $7 D$ & 102.55 & 4.38 & $\begin{array}{l}100.36- \\
104.74\end{array}$ & 24 & $\begin{array}{l}\text { GW(11), } \\
\text { GN(3), } \\
\text { SLN(2), } \\
\text { TN(2) }\end{array}$ & $\begin{array}{l}461.68- \\
582.09\end{array}$ & Xcfd193-Xbarc172 \\
\hline 143 & $\begin{array}{l}\text { MQTL- } \\
7 D-7\end{array}$ & 7D & 110.41 & 1.64 & $\begin{array}{l}109.59- \\
111.23\end{array}$ & 5 & $\begin{array}{l}\operatorname{TN}(3) \\
\text { GW(1), } \\
\text { SLN(1) }\end{array}$ & $\begin{array}{l}536.50- \\
564.85\end{array}$ & Xgdm46-Xwmc797 \\
\hline 144 & $\begin{array}{l}\text { MQTL- } \\
\text { 7D-8 }\end{array}$ & 7D & 125.89 & 1.45 & $\begin{array}{l}125.17- \\
126.62\end{array}$ & 5 & $\begin{array}{l}\text { GN(2), } \\
\text { GW(1), } \\
\text { TN(1), } \\
\text { SLN(1) }\end{array}$ & $\begin{array}{l}589.06- \\
611.52\end{array}$ & Xwmc671-Xwmc824 \\
\hline 145 & $\begin{array}{l}\text { MQTL- } \\
\text { 7D-9 }\end{array}$ & $7 D$ & 173.45 & 1.92 & $\begin{array}{l}172.49- \\
174.41\end{array}$ & 8 & $\begin{array}{l}\text { GW(3), } \\
\text { GY(3), } \\
\text { SLN(1), } \\
\text { TN(1) }\end{array}$ & $\begin{array}{l}588.55- \\
593.24\end{array}$ & $\begin{array}{l}\text { D_GCE8AKX02IGVBN_58- } \\
\text { D_contig12731_156 }\end{array}$ \\
\hline
\end{tabular}

a Chromosomes

b The most likely position on consensus map

c The confidence interval (95\%) of MQTL on consensus map

d GW, Grain weight; GN, Grain number; GY, Grain yield; TN, Tiller number; SL, Spike length; SLN, Spikelet number; GFR, Grain-filling rate; $\mathrm{BY}$, Biomass; $\mathrm{HI}$, Harvest index.

Each MQTL only lists the trait types of the top five QTLs.

Bold MQTL represents the core MQTL region

Table 2. The GWAS (Genome-Wide Association Study) researches on yield and yield-related traits used in this study. 


\begin{tabular}{|c|c|c|c|c|c|c|c|c|}
\hline No & $\begin{array}{l}\text { Source of } \\
\text { genotype }\end{array}$ & Pop ${ }^{a}$ & $\begin{array}{l}\text { Marker } \\
\text { type/number }\end{array}$ & Model & $\begin{array}{l}\text { Number } \\
\text { of } \\
\text { MTA }^{b}\end{array}$ & Trait & Environment & Reference \\
\hline \multirow[t]{2}{*}{1} & \multirow{2}{*}{$\begin{array}{l}\text { CIMMYT, ESWYT, } \\
\text { SAWYT, HTWYT, } \\
\text { Spring wheat }\end{array}$} & \multirow[t]{2}{*}{287} & \multirow[t]{2}{*}{ DArT/1863 } & \multirow[t]{2}{*}{ MLM } & \multirow[t]{2}{*}{565} & \multirow[t]{2}{*}{$\begin{array}{l}26 \text { agronomic } \\
\text { and yield traits }\end{array}$} & $\begin{array}{l}\text { Greeley, CO, } \\
\text { USA; }\end{array}$ & \multirow[t]{2}{*}{$\begin{array}{l}\text { Edae et al. } \\
2014\end{array}$} \\
\hline & & & & & & & $\begin{array}{l}\text { Melkassa, } \\
\text { Ethiopia }\end{array}$ & \\
\hline 2 & $\begin{array}{l}\text { Chinese winter } \\
\text { wheat cultivars } \\
\text { collected from } \\
\text { Yellow and Huai } \\
\text { Valley }\end{array}$ & 163 & SNP/20689 & MLM & 1769 & $\begin{array}{l}13 \text { yield-related } \\
\text { traits }\end{array}$ & $\begin{array}{l}\text { Zhengzhou, } \\
\text { Anyang and } \\
\text { Zhumadian, } \\
\text { China }\end{array}$ & $\begin{array}{l}\text { Sun et al. } \\
2017\end{array}$ \\
\hline 3 & $\begin{array}{l}\text { WAMI spring } \\
\text { wheat population } \\
\text { from CIMMYT }\end{array}$ & 287 & SNP/18704 & MLM & 31 & $\begin{array}{l}16 \text { yield-related } \\
\text { traits }\end{array}$ & $\begin{array}{l}\text { Ciudad } \\
\text { Obregón and } \\
\text { Sonora State, } \\
\text { Northwest } \\
\text { Mexico }\end{array}$ & $\begin{array}{l}\text { Sukumarar } \\
\text { et al. } 2015\end{array}$ \\
\hline 4 & $\begin{array}{l}\text { Pakistani } \\
\text { historical spring } \\
\text { wheat cultivars }\end{array}$ & 123 & SNP/14960 & MLM & 44 & $\begin{array}{l}9 \text { yield-related } \\
\text { traits }\end{array}$ & $\begin{array}{l}\text { Islamabad, } \\
\text { Pakista }\end{array}$ & $\begin{array}{l}\text { Ain et al. } \\
2015\end{array}$ \\
\hline 6 & $\begin{array}{l}\text { German hexaploid } \\
\text { winter wheat } \\
\text { cultivars }\end{array}$ & 210 & SNP/7928 & MLM & 218 & $\begin{array}{l}16 \text { floret fertility } \\
\text { traits and } 38 \\
\text { traits for } \\
\text { assimilate } \\
\text { partitioning and } \\
\text { spike } \\
\text { morphology }\end{array}$ & $\begin{array}{l}\text { Gatersleben, } \\
\text { Germany }\end{array}$ & $\begin{array}{l}\text { Guo et al. } \\
2017\end{array}$ \\
\hline 7 & $\begin{array}{l}\text { Chinese winter } \\
\text { wheat founder } \\
\text { parents, } \\
\text { derivatives, and } \\
\text { cultivars }\end{array}$ & 215 & SNP/4138 & MLM & 76 & $\begin{array}{l}6 \text { yield-related } \\
\text { traits }\end{array}$ & $\begin{array}{l}\text { Taian, } \\
\text { Yangling and } \\
\text { Yangzhou, } \\
\text { China }\end{array}$ & $\begin{array}{l}\text { Guo et al. } \\
2018\end{array}$ \\
\hline 8 & $\begin{array}{l}\text { Synthetic } \\
\text { hexaploid winter } \\
\text { wheat lines, } \\
\text { landraces, and } \\
\text { cultivars }\end{array}$ & 192 & SNP/13154 & CMLM & 147 & $\begin{array}{l}4 \text { yield-related } \\
\text { traits }\end{array}$ & $\begin{array}{l}\text { Shuangliu and } \\
\text { Shifang, China }\end{array}$ & $\begin{array}{l}\text { Liu et al. } \\
2018\end{array}$ \\
\hline 9 & $\begin{array}{l}\text { Chinese winter } \\
\text { wheat }\end{array}$ & 205 & SNP/24355 & MLM & 271 & $\begin{array}{l}\text { yield-related } \\
\text { traits }\end{array}$ & $\begin{array}{l}\text { Taian and } \\
\text { Dezhou, China }\end{array}$ & $\begin{array}{l}\text { Chen et al. } \\
2016\end{array}$ \\
\hline 10 & $\begin{array}{l}\text { European winter } \\
\text { wheat, spring } \\
\text { wheat varieties }\end{array}$ & 372 & $\begin{array}{l}\text { SNP/7761, } \\
\text { SSR/635 }\end{array}$ & MLM & 1537 & $\begin{array}{l}\text { Thousand grain } \\
\text { weight }\end{array}$ & $\begin{array}{l}\text { Andelu, } \\
\text { Janville and } \\
\text { Saultain, } \\
\text { France; } \\
\text { Seligenstadt } \\
\text { and Wohlde, } \\
\text { Germany }\end{array}$ & $\begin{array}{l}\text { Zanke et al } \\
2015\end{array}$ \\
\hline 12 & $\begin{array}{l}\text { Chinese winter } \\
\text { wheat }\end{array}$ & 688 & SNP/20065 & MLM & 337 & $\begin{array}{l}\text { Thousand grain } \\
\text { weight }\end{array}$ & $\begin{array}{l}\text { Xianyang, } \\
\text { Shijiazhuang } \\
\text { and Linfen, } \\
\text { China }\end{array}$ & $\begin{array}{l}\text { Wang et al. } \\
2020 \text { a }\end{array}$ \\
\hline
\end{tabular}

a The size of population used for GWAS

b The number of marker-trait association (MTA) detected in previous GWAS researches.

Table 3. Representative candidate genes with significant contribution to yield-related traits. 


\begin{tabular}{|c|c|c|c|c|}
\hline MQTL & $\begin{array}{l}\text { Main Traits } \\
\text { affected by } \\
\text { MQTLs }\end{array}$ & $\begin{array}{l}\text { Candidate gene within } \\
\text { MQTL (IWGSC v 1.1) }\end{array}$ & $\begin{array}{l}\text { Orthlogue } \\
\text { in rice }\end{array}$ & The function of Orthlogue in rice ${ }^{a}$ \\
\hline $\begin{array}{l}\text { MQTL- } \\
1 \mathrm{~A}-2\end{array}$ & $\mathrm{GN}(10)$ & TraesCS1A02G026000 & $\begin{array}{l}\text { Target gene } \\
\text { of } \\
\text { Osa- } \\
\text { miR1873 }\end{array}$ & Grain number (-), Grain size (-), Plant height (-) \\
\hline & $\mathrm{TN}(5)$ & TraesCS1A02G031200 & OsRLCK57 & $\begin{array}{l}\text { Tiller number }(+) \text {, Number of secondary branch per } \\
\text { panicle }(+) \text {, Leaf angle }(-)\end{array}$ \\
\hline $\begin{array}{l}\text { MQTL- } \\
1 A-3\end{array}$ & $\begin{array}{l}\text { GW(4), } \\
\text { GN(2), } \\
\text { SLN(2) }\end{array}$ & TraesCS1A02G045300 & OsMKP1 & $\begin{array}{l}\text { Grain length }(-) \text {, Grain width }(-) \text {, Grain weight }(-) \text {, Spikelet } \\
\text { number }(+) \text {, Grain number }(+) \text {, Number of first and } \\
\text { secondary branches per panicle }(+)\end{array}$ \\
\hline $\begin{array}{l}\text { MQTL- } \\
1 \mathrm{~A}-4\end{array}$ & $\begin{array}{l}\mathrm{GN}(5) \\
\mathrm{GW}(3) \\
\mathrm{GY}(2)\end{array}$ & TraesCS1A02G083100 & MYB61 & $\begin{array}{l}\text { Cellulose content }(+) \text {, Nitrogen use efficiency }(+) \text {, Grain } \\
\text { number }(+) \text {, Grain weight }(+) \text {, Grain yield }(+)\end{array}$ \\
\hline $\begin{array}{l}\text { MQTL- } \\
1 \mathrm{~A}-5\end{array}$ & $\begin{array}{l}\mathrm{GW}(5) \\
\mathrm{GY}(4)\end{array}$ & TraesCS1A02G407700 & qTGW3 & Grain length $(-)$, Grain weight $(-)$ \\
\hline $\begin{array}{l}\text { MQTL- } \\
1 \mathrm{~B}-3\end{array}$ & $\begin{array}{l}\mathrm{GW}(12) \\
\mathrm{GN}(8), \mathrm{GY}(5)\end{array}$ & TraesCS1B02G058600 & OsMKP1 & $\begin{array}{l}\text { Grain length }(-) \text {, Grain width }(-) \text {, Grain weight }(-) \text {, Spikelet } \\
\text { number }(+) \text {, Grain number }(+) \text {, Number of first and } \\
\text { secondary branches per panicle }(+)\end{array}$ \\
\hline $\begin{array}{l}\text { MQTL- } \\
1 \mathrm{~B}-4\end{array}$ & $\begin{array}{l}\mathrm{GN}(4) \\
\mathrm{GW}(3)\end{array}$ & TraesCS1B02G320100 & OsVQ4 & Grain weight $(+)$, Grain number $(-)$, Date to heading $(-)$ \\
\hline $\begin{array}{l}\text { MQTL- } \\
1 \mathrm{D}-1\end{array}$ & $\mathrm{GN}(2)$ & TraesCS1D02G004000 & PTB1 & Grain number (+) \\
\hline $\begin{array}{l}\text { MQTL- } \\
2 A-6\end{array}$ & $\mathrm{GW}(3)$ & TraesCS2A02G464000 & GSD1 & $\begin{array}{l}\text { Grain number }(+) \text {, Grain weight }(+) \text {, Grain width }(+) \text {, } \\
\text { Soluble sugar content in xylem permeate }(+) \text {, Starch } \\
\text { content in leaves }(-)\end{array}$ \\
\hline $\begin{array}{l}\text { MQTL- } \\
2 A-7\end{array}$ & $\begin{array}{l}\mathrm{TN}(2), \mathrm{SL}(2) \\
\mathrm{GN}(2)\end{array}$ & TraesCS2A02G491900 & MOC3 & $\begin{array}{l}\text { Tiller number }(+) \text {, Grain number }(+) \text {, Floral organ } \\
\text { development }(+) \text {, Spike length }(-)\end{array}$ \\
\hline $\begin{array}{l}\text { MQTL- } \\
2 B-1\end{array}$ & $\begin{array}{l}\mathrm{GN}(9) \\
\mathrm{GW}(6)\end{array}$ & TraesCS2B02G023800 & OSETR2 & $\begin{array}{l}\text { Flowering date }(-) \text {, Grain weight }(-) \text {, Tiller number }(-) \text {, } \\
\text { Grain number }(-)\end{array}$ \\
\hline $\begin{array}{l}\text { MQTL- } \\
2 D-6\end{array}$ & $\begin{array}{l}\mathrm{GW}(9) \\
\mathrm{GN}(1)\end{array}$ & TraesCS2D02G464900 & GSD1 & $\begin{array}{l}\text { Grain number (+), Grain weight (+), Grain width }(+) \text {, } \\
\text { Soluble sugar content in xylem permeate }(+) \text {, Starch } \\
\text { content in leaves }(-)\end{array}$ \\
\hline $\begin{array}{l}\text { MQTL- } \\
3 A-4\end{array}$ & $\begin{array}{l}\mathrm{GN}(10) \\
\mathrm{TN}(9)\end{array}$ & TraesCS3A02G377600 & MOC2 & $\begin{array}{l}\text { Tiller number (+), Plant height }(+) \text {, Chlorophyll content } \\
(+) \text {, Spike length }(+) \text {, Grain number }(+)\end{array}$ \\
\hline $\begin{array}{l}\text { MQTL- } \\
3 B-5\end{array}$ & $\mathrm{TN}(9)$ & TraesCS3B02G348200 & $A L T 1$ & Tiller number $(+)$ \\
\hline $\begin{array}{l}\text { MQTL- } \\
3 \mathrm{D}-3\end{array}$ & $\begin{array}{l}\mathrm{GW}(9) \\
\mathrm{TN}(7), \mathrm{GN}(5)\end{array}$ & TraesCS3D02G106100 & $D 2$ & $\begin{array}{l}\text { Plant height }(+) \text {, Leaf angle }(+) \text {, Grain size }(+) \text {, } \\
\text { Brassinolide content }(+) \text {, Grain weight }(+) \text {, Cell size }(+) \text {, } \\
\text { Tiller number }(-) \text {, Grain number }(-)\end{array}$ \\
\hline $\begin{array}{l}\text { MQTL- } \\
4 A-1\end{array}$ & $\mathrm{GW}(5)$ & TraesCS4A02G005600 & OsLG3 & $\begin{array}{l}\text { Grain length }(+) \text {, Grain length/width }(+) \text {, Grain yield }(+) \text {, } \\
\text { Grain weight }(+)\end{array}$ \\
\hline $\begin{array}{l}\text { MQTL- } \\
4 A-2\end{array}$ & GN(5), GY(3) & TraesCS4A02G319100 & OsGA20ox 1 & $\begin{array}{l}\text { Gibberellin content }(+) \text {, Grain number }(+) \text {, Number of } \\
\text { secondary branch per panicle }(+) \text {, Grain yield }(+)\end{array}$ \\
\hline $\begin{array}{l}\text { MQTL- } \\
4 A-3\end{array}$ & $\begin{array}{l}\mathrm{GW}(7) \\
\mathrm{GN}(1)\end{array}$ & TraesCS4A02G286700 & OsFdC2 & $\begin{array}{l}\text { Plant height }(+) \text {, Tiller number }(+) \text {, Date to heading }(+) \text {, } \\
\text { Grain number }(+) \text {, Grain weight }(+) \text {, Grain number }(+), \\
\text { Chlorophyll content }(+) \text {, Carotenoid content }(+)\end{array}$ \\
\hline $\begin{array}{l}\text { MQTL- } \\
4 A-6\end{array}$ & $\begin{array}{l}\mathrm{GW}(13) \\
\mathrm{GN}(9)\end{array}$ & TraesCS4A02G388400 & OsFIE1 & $\begin{array}{l}\text { Grain size }(+) \text {, Grain number }(+) \text {, Grain weight }(+) \text {, Pollen } \\
\text { fertility }(+) \text {, Photosynthesis }(+)\end{array}$ \\
\hline
\end{tabular}




\begin{tabular}{|c|c|c|c|c|}
\hline MQTL & $\begin{array}{l}\text { Main Traits } \\
\text { affected by } \\
\text { MQTLs }\end{array}$ & $\begin{array}{l}\text { Candidate gene within } \\
\text { MQTL (IWGSC v 1.1) }\end{array}$ & $\begin{array}{l}\text { Orthlogue } \\
\text { in rice }\end{array}$ & The function of Orthlogue in rice ${ }^{a}$ \\
\hline $\begin{array}{l}\text { MQTL- } \\
4 A-8\end{array}$ & $\begin{array}{l}\operatorname{TN}(2), \operatorname{SL}(2) \\
\operatorname{SLN}(1) \\
\mathrm{GN}(1), \mathrm{GY}(1)\end{array}$ & TraesCS4A02G460100 & OsKAO & $\begin{array}{l}\text { Grain yield }(+) \text {, Grain weight }(+) \text {, Grains per panicle }(+) \text {, } \\
\text { Gibberellin content }(+) \text {, Number of secondary branches } \\
(+)\end{array}$ \\
\hline $\begin{array}{l}\text { MQTL- } \\
\text { 4B-2 }\end{array}$ & $\mathrm{TN}(8)$ & TraesCS4B02G019300 & OsIRT1 & $\begin{array}{l}\text { Tiller number (-), Plant height (-), Iron and zinc ion } \\
\text { sensitivity }(-)\end{array}$ \\
\hline $\begin{array}{l}\text { MQTL- } \\
4 \mathrm{~B}-3\end{array}$ & $\begin{array}{l}\text { GW(9), } \\
\text { TN(7), } \\
\text { GN(5), GY(6) }\end{array}$ & TraesCS4B02G028100 & OsFdC2 & $\begin{array}{l}\text { Plant height }(+) \text {, Tiller number }(+) \text {, Date to heading }(+) \text {, } \\
\text { Grain number }(+) \text {, Grain weight }(+) \text {, Grain number }(+), \\
\text { Chlorophyll content }(+) \text {, Carotenoid content }(+)+\mathrm{H} 120\end{array}$ \\
\hline $\begin{array}{l}\text { MQTL- } \\
4 \mathrm{~B}-5\end{array}$ & $\begin{array}{l}\mathrm{GW}(11) \\
\mathrm{TN}(2) \\
\mathrm{GN}(1), \mathrm{SL}(1)\end{array}$ & TraesCS4B02G214000 & pls2 & $\begin{array}{l}\text { Photosynthesis }(+) \text {, Plant height }(+) \text {, Spike length }(+) \text {, } \\
\text { Tiller number }(+) \text {, Grain number }(+) \text {, Grain weight }(+) \text {, } \\
\text { Grain filling }(+) \text {, Chloroplast development }(+)\end{array}$ \\
\hline $\begin{array}{l}\text { MQTL- } \\
4 \mathrm{D}-2\end{array}$ & $\begin{array}{l}\mathrm{GW}(8), \\
\mathrm{TN}(3), \mathrm{GN}(2)\end{array}$ & TraesCS4D02G025700 & OsFdC2 & $\begin{array}{l}\text { Plant height }(+) \text {, Tiller number }(+), \text { Date to heading }(+) \text {, } \\
\text { Grain number }(+) \text {, Grain weight }(+) \text {, Grain number }(+) \text {, } \\
\text { Chlorophyll content }(+) \text {, Carotenoid content }(+)\end{array}$ \\
\hline $\begin{array}{l}\text { MQTL- } \\
5 A-2\end{array}$ & $\mathrm{GW}(22)$ & TraesCS5A02G286700 & $q G W 8$ & Grain size $(-)$, Grain weight $(-)$, Cooking quality (-) \\
\hline \multirow{3}{*}{$\begin{array}{l}\text { MQTL- } \\
5 A-3\end{array}$} & $\mathrm{GW}(18)$ & TraesCS5A02G394500 & GSA1 & Grain size $(+)$, Grain weight $(+)$ \\
\hline & GW(18) & TraesCS5A02G394800 & GSA1 & Grain size $(+)$, Grain weight $(+)$ \\
\hline & GW(18) & TraesCS5A02G395200 & OsPho1 & $\begin{array}{l}\text { Grain size }(+) \text {, Grain yield }(+) \text {, Starch structure and } \\
\text { content }(+) \text {, Grain weight }(+)\end{array}$ \\
\hline \multirow[t]{4}{*}{$\begin{array}{l}\text { MQTL- } \\
5 A-7\end{array}$} & $\mathrm{GW}(8)$ & TraesCS5A02G500500 & ONACO22 & $\begin{array}{l}\text { Plant height }(-) \text {, Spike length }(-) \text {, Grain number }(-) \text {, Grain } \\
\text { weight }(-) \text {, Abscisic acid sensitivity }(+) \text {, Drought } \\
\text { resistance }(+) \text {, Salt tolerance }(+)\end{array}$ \\
\hline & $\mathrm{GN}(5)$ & TraesCS5A02G508500 & POT & Grain number (+) \\
\hline & $\begin{array}{l}\mathrm{GN}(5), \\
\mathrm{GY}(4), \mathrm{TN}(3)\end{array}$ & TraesCS5A02G511300 & PROG1 & $\begin{array}{l}\text { Plant height }(+) \text {, Grain number }(+) \text {, Grain yield }(+) \text {, Tiller } \\
\text { number }(+) \text {, Tiller angle }(+)\end{array}$ \\
\hline & $\begin{array}{l}\mathrm{GN}(5) \\
\mathrm{GY}(4), \mathrm{TN}(3)\end{array}$ & TraesCS5A02G511400 & PROG1 & $\begin{array}{l}\text { Plant height }(+) \text {, Grain number }(+) \text {, Grain yield }(+) \text {, Tiller } \\
\text { number }(+) \text {, Tiller angle }(+)\end{array}$ \\
\hline $\begin{array}{l}\text { MQTL- } \\
6 A-4\end{array}$ & $\begin{array}{l}\mathrm{GW}(7) \\
\mathrm{DTH}(2)\end{array}$ & TraesCS6A02G287300 & OsNF-YB9 & $\begin{array}{l}\text { Date to heading }(-) \text {, Leaf angle }(-) \text {, Pollen vitality }(-) \text {, Grain } \\
\text { size }(-) \text {, Grain weight }(-) \text {, Cell number }(+)\end{array}$ \\
\hline \multirow[t]{2}{*}{$\begin{array}{l}\text { MQTL- } \\
6 \mathrm{~B}-3\end{array}$} & $\begin{array}{l}\mathrm{GW}(10) \\
\mathrm{TN}(1), \mathrm{GN}(2)\end{array}$ & TraesCS6B02G152900 & LRK1 & $\begin{array}{l}\text { Tiller number (+), Number of secondary branch per } \\
\text { panicle }(+) \text {, Grain number }(+) \text {, Grain yield }(+) \text {, Plant height } \\
(-) \text {, Grain weight }(-)\end{array}$ \\
\hline & $\begin{array}{l}\mathrm{GW}(10) \\
\mathrm{TN}(1), \mathrm{GN}(2)\end{array}$ & TraesCS6B02G153100 & $L R K 1$ & $\begin{array}{l}\text { Tiller number }(+) \text {, Number of secondary branch per } \\
\text { panicle }(+) \text {, Grain number }(+) \text {, Grain yield }(+) \text {, Plant height } \\
(-) \text {, Grain weight }(-)\end{array}$ \\
\hline $\begin{array}{l}\text { MQTL- } \\
6 \mathrm{~B}-5\end{array}$ & $\mathrm{GW}(6)$ & TraesCS6B02G430100 & OsNDUFA9 & $\begin{array}{l}\text { Endosperm development }(+) \text {, Grain weight }(+) \text {, Starch } \\
\text { granule formation }(+) \text {, Germination rate }(+)\end{array}$ \\
\hline $\begin{array}{l}\text { MQTL- } \\
6 D-5\end{array}$ & $\begin{array}{l}\mathrm{GN}(5) \\
\mathrm{GW}(2)\end{array}$ & TraesCS6D02G361900 & TH1 & $\begin{array}{l}\text { Grain length }(+) \text {, Grain thickness }(+) \text {, Grain weight }(+) \text {, } \\
\text { Starch granule morphology }(+) \text {, Grain number }(+), \\
\text { Morphological and anatomical traits of palea and glume } \\
(+)\end{array}$ \\
\hline $\begin{array}{l}\text { MQTL- } \\
7 A-4\end{array}$ & $\mathrm{GW}(6)$ & TraesCS7A02G120000 & HGW & Grain weight (+), Date to heading (+) \\
\hline $\begin{array}{l}\text { MQTL- } \\
7 A-7\end{array}$ & $\begin{array}{l}\mathrm{GN}(5) \\
\mathrm{GW}(4)\end{array}$ & TraesCS7A02G154900 & OsMKK4 & $\begin{array}{l}\text { Grain number }(-) \text {, Grain length }(+) \text {, Grain width }(+) \text {, Plant } \\
\text { height }(+) \text {, Grain weight }(+) \text {, Cytokinin content }(+)\end{array}$ \\
\hline
\end{tabular}




\begin{tabular}{|lllll|}
\hline MQTL & $\begin{array}{l}\text { Main Traits } \\
\text { affected by } \\
\text { MQTLs }\end{array}$ & $\begin{array}{l}\text { Candidate gene within } \\
\text { MQTL (IWGSC v 1.1) }\end{array}$ & $\begin{array}{l}\text { Orthlogue } \\
\text { in rice }\end{array}$ & The function of Orthlogue in rice $^{\text {a }}$ \\
\hline $\begin{array}{l}\text { MQTL- } \\
\text { 7B-2 }\end{array}$ & $\begin{array}{l}\text { GW(6), } \\
\text { DTH(1) }\end{array}$ & TraesCS7B02G018300 & HGW & Grain weight (+), Date to heading (+) \\
\hline $\begin{array}{l}\text { MQTL- } \\
\text { 7B-4 }\end{array}$ & $\begin{array}{l}\text { GW(9), } \\
\text { GN(1) }\end{array}$ & TraesCS7B02G381500 & GL6 & Grain length (+), Grain weight (+), Grain number (-) \\
\hline $\begin{array}{l}\text { MQTL- } \\
7 D-2\end{array}$ & SLN(2) & TraesCS7D02G468700 & OSAPO1 & $\begin{array}{l}\text { Spike length (+), Number of first branch per panicle (+), } \\
\text { Spikelet number (+), Stem thickness (+) }\end{array}$ \\
\hline $\begin{array}{l}\text { MQTL- } \\
7 D-6\end{array}$ & $\begin{array}{l}\text { GW(11), } \\
\text { GN(3) }\end{array}$ & TraesCS7D02G466400 & GL6 & Grain length (+), Grain weight (+), Grain number (-) \\
\hline
\end{tabular}

$a^{\prime}+{ }^{\prime}$ and ' - ' in brackets represent the positive and negative regulation of yield-related traits in rice, respectively. The core traits were shown in bold.

\section{Figures}

a
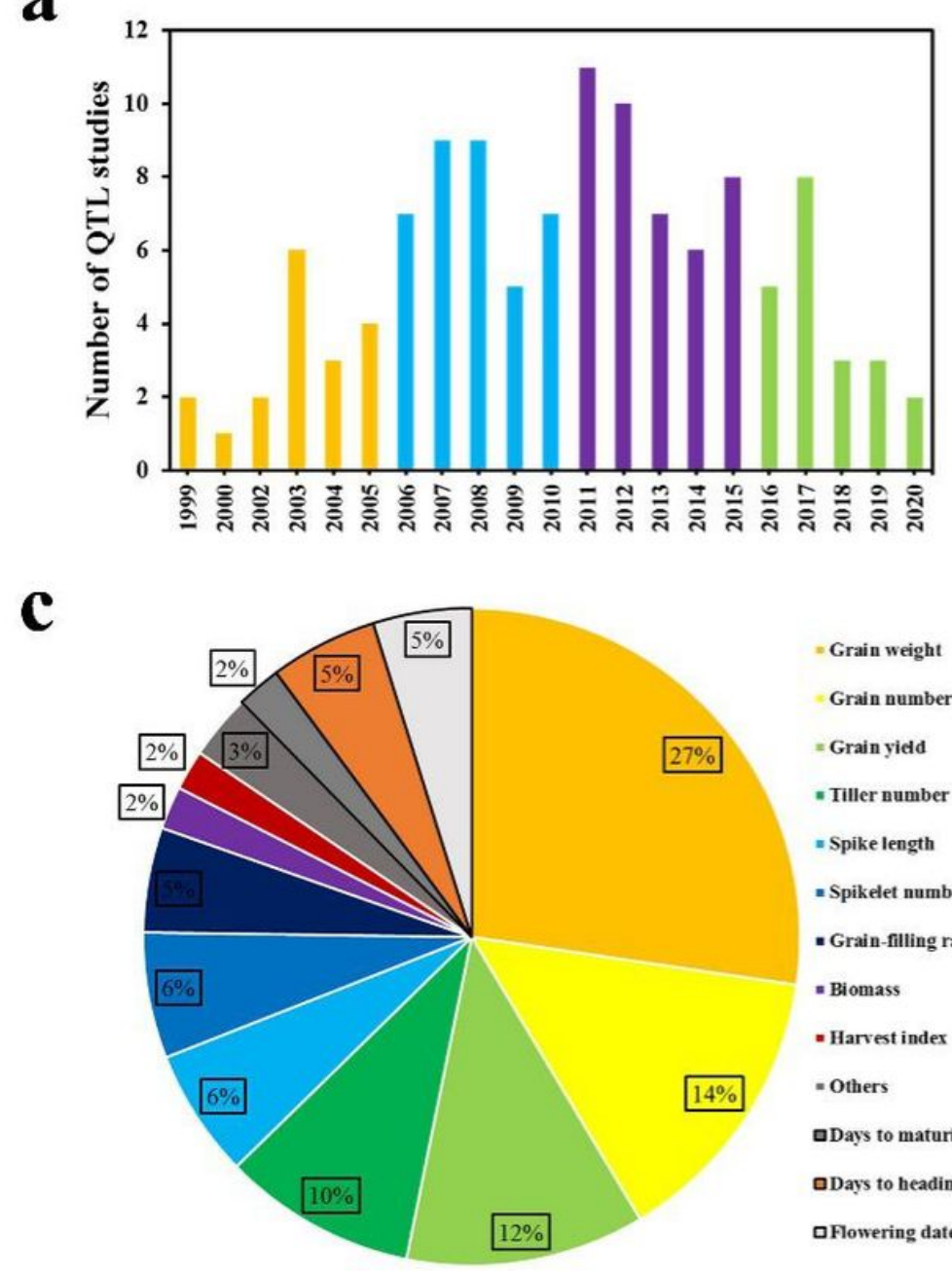

b

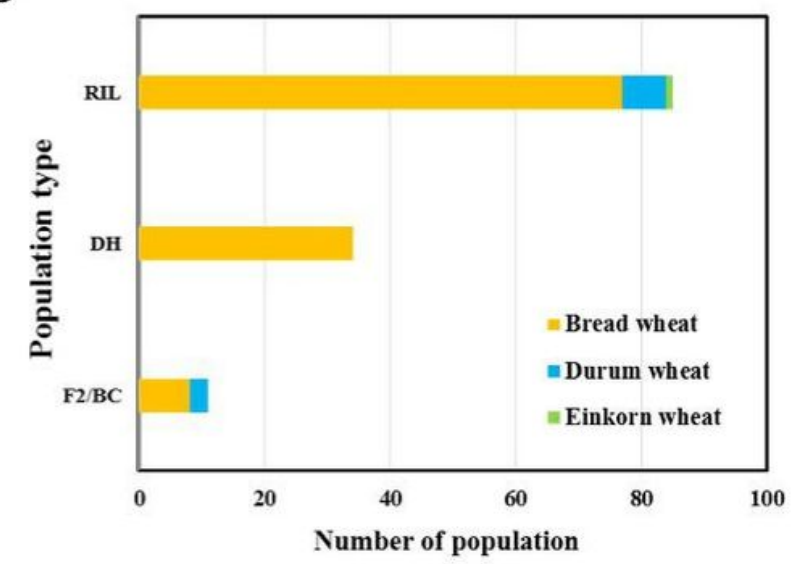

d

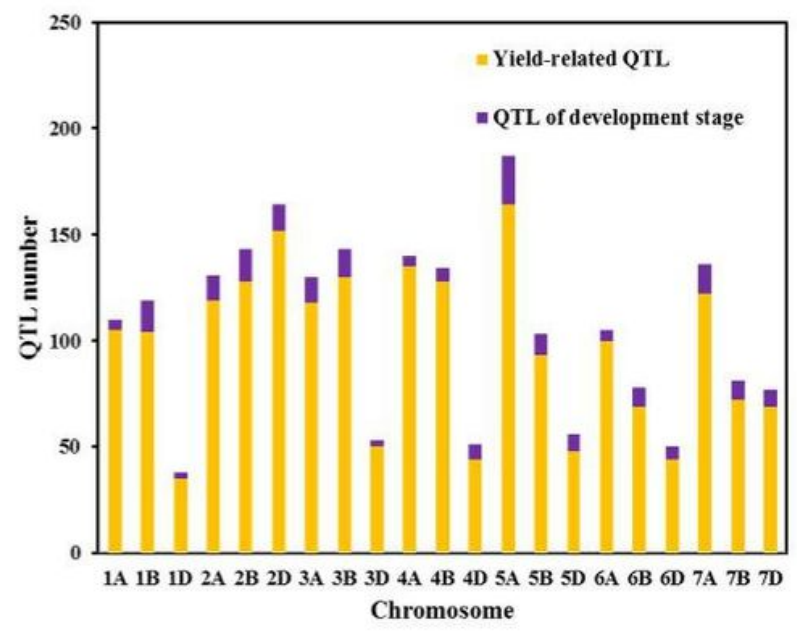

Figure 1 
The information of QTLs for wheat yield and yield-related traits in previous QTL mapping studies used for Meta-QTL analysis. (a) The time distribution of previous QTL mapping studies. (b) The population type of pervious QTL mapping studies. (c) The proportion of QTLs for different yield and yield-related traits. (d) The distribution of QTLs on chromosomes. The QTLs of yieldrelated traits and development stage were marked in $\mathrm{c}$ and $\mathrm{d}$.

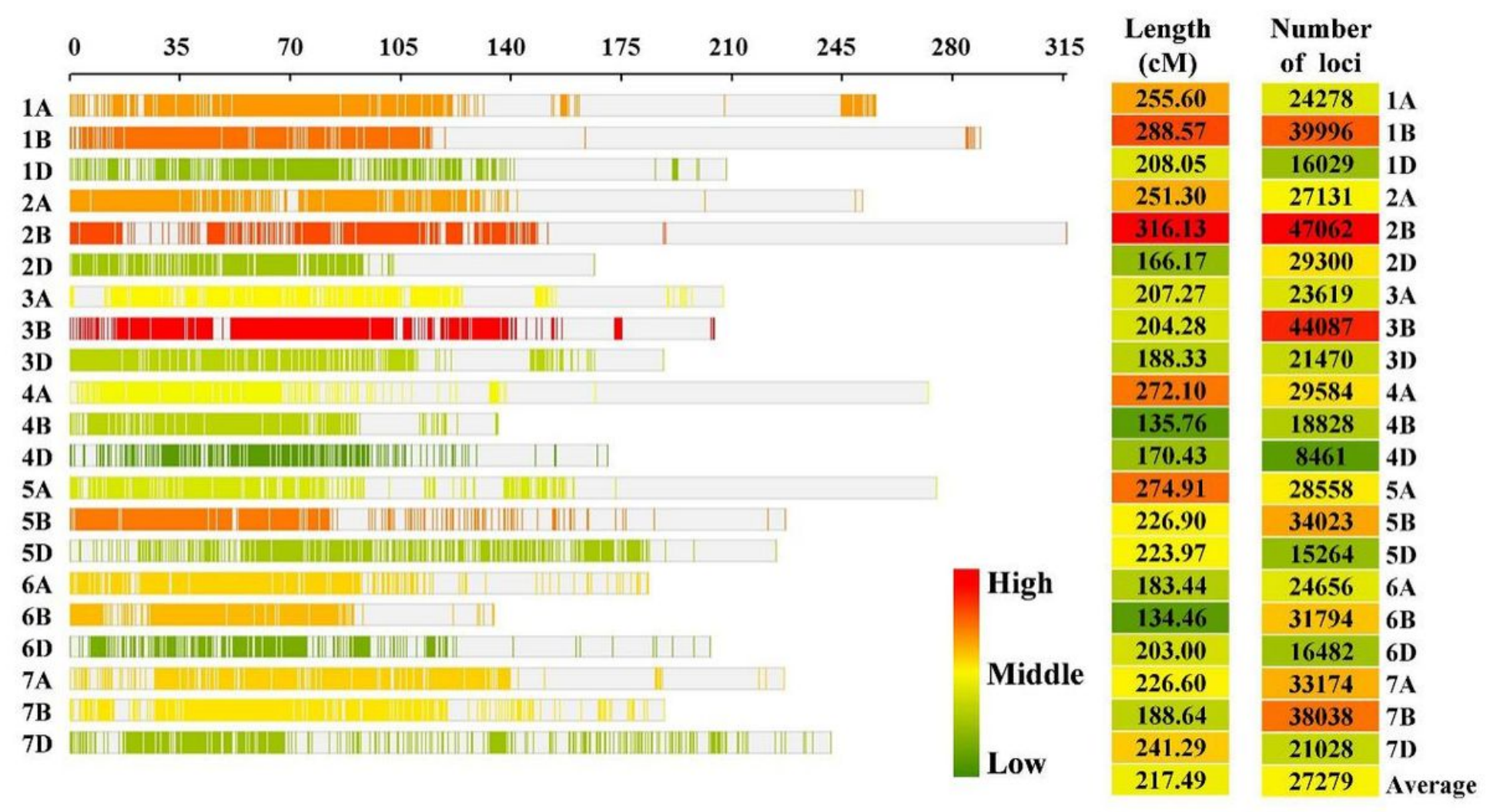

Figure 2

Marker distribution on the consensus genetic map used for Meta-QTL analysis. From red to green, the marker density in chromosome, the genetic length of chromosome, and the number of markers in chromosome decreases from high to low. 
$\mathbf{a}$

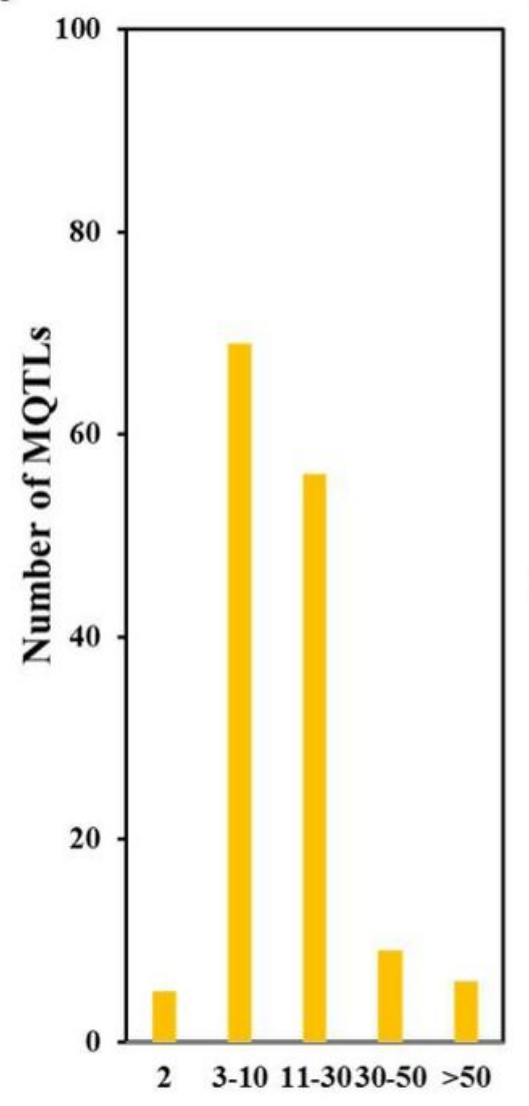

b

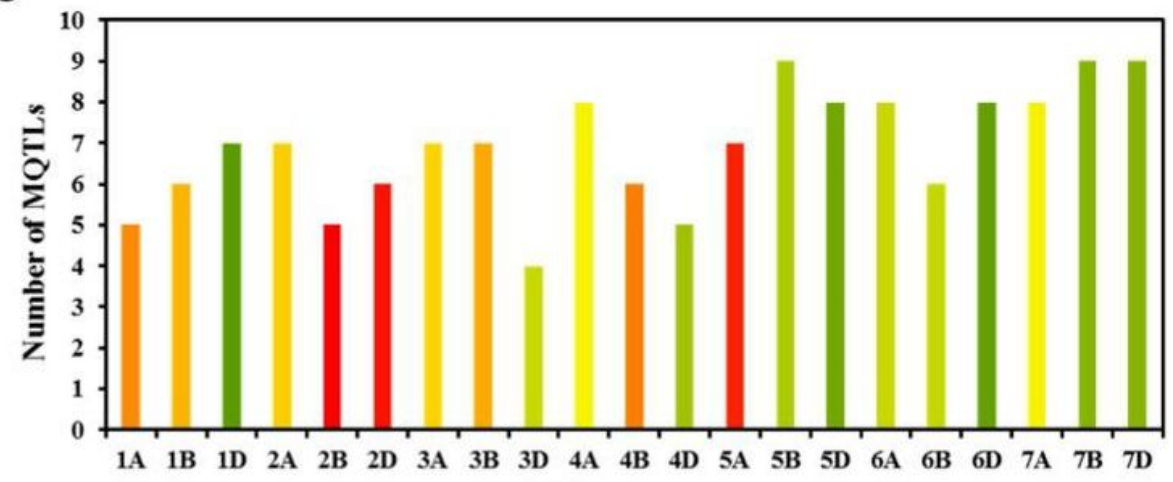

Chromosome

High

C

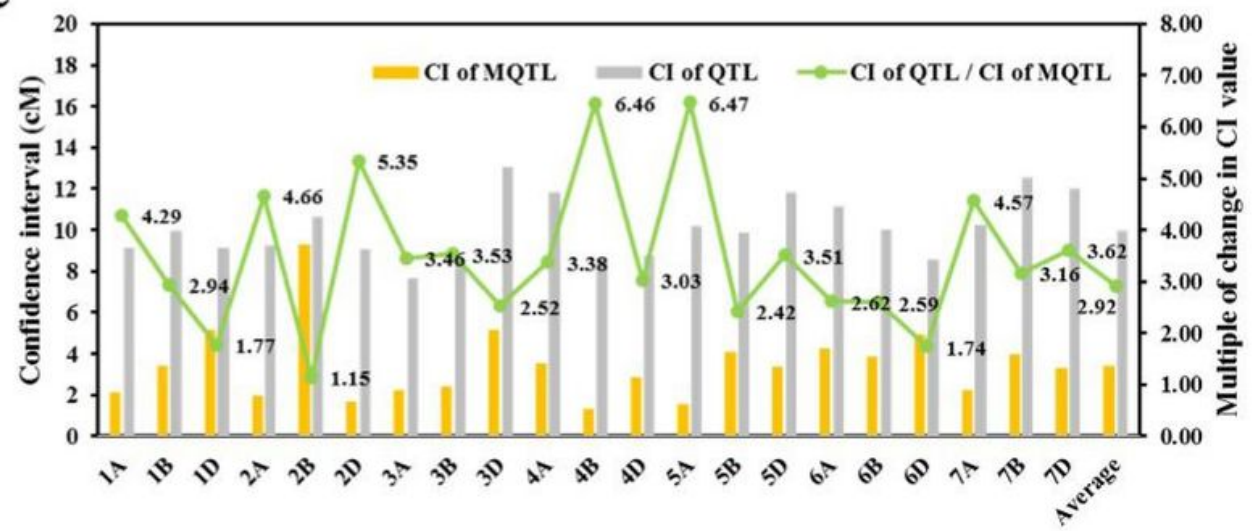

Figure 3

Basic information of MQTL obtained in Meta-QTL analysis. (a) Number of MQTLs harboring different number of QTLs. (b) The number of MQTLs and average number of initial QTLs projected on a single MQTL in different chromosomes. From red to green, the number of QTLs contained in MQTL decreases from high to low. (c) The reduction degree of QTL confidence interval (Cl, 95\%) after Meta-QTL analysis. The orange and gray bars represent the average $\mathrm{Cl}$ length (cM) of MQTL and initial QTL on chromosome, respectively, and the broken line represents the reduction folds of the QTL CI length. 


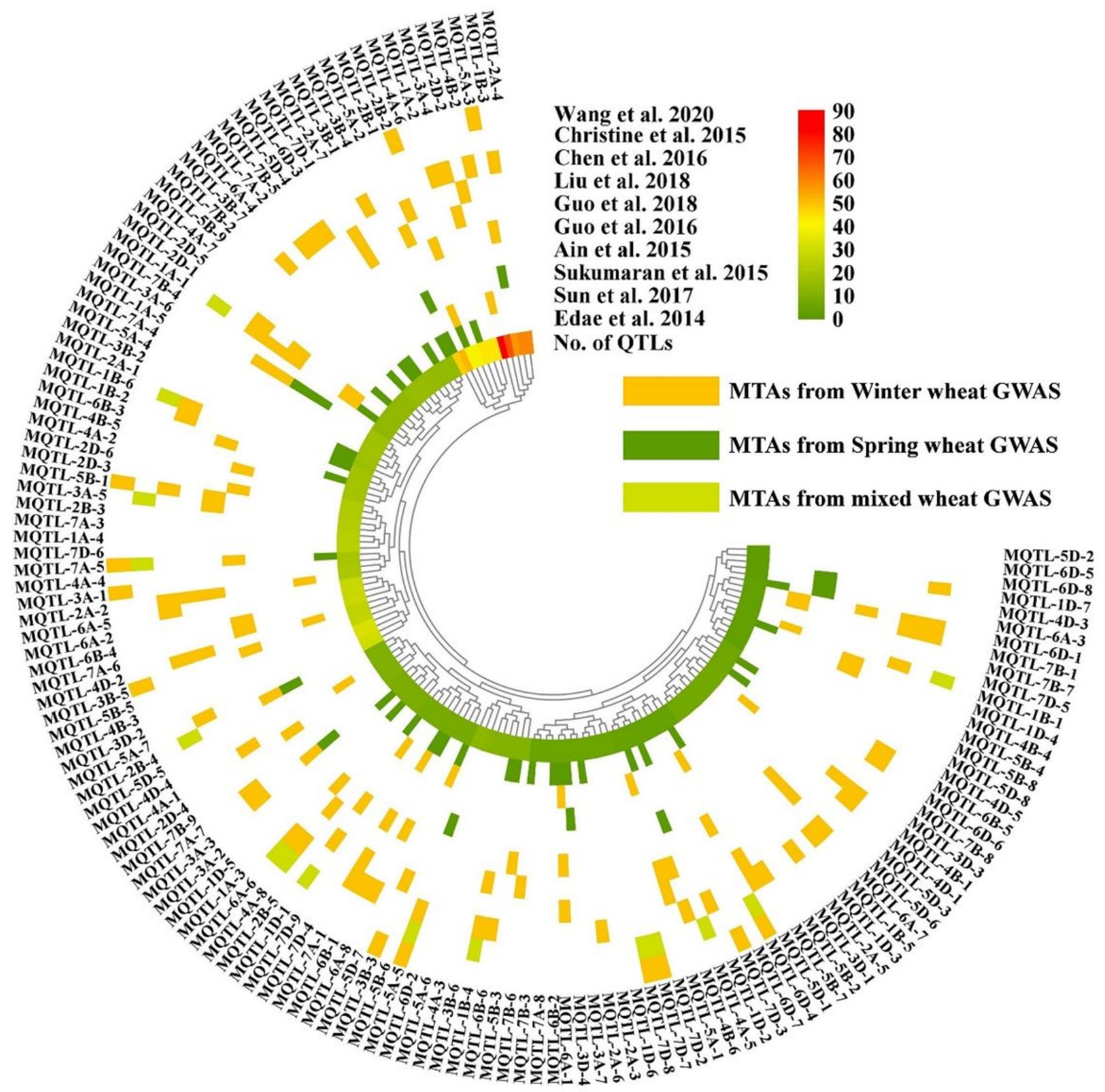

Figure 4

Validation of MQTL by MTAs on wheat yield and yield-related traits from GWAS with 10 different natural populations. The innermost ring represents the clustering of QTL numbers that make up different MQTL. From red to blue, the number of initial QTLs contained in the MQTLs decreases from high to low. The color squares in the outer rings represent the co-location of MQTLs with marker-trait association (MTA) obtained from GWAS with different natural populations. 


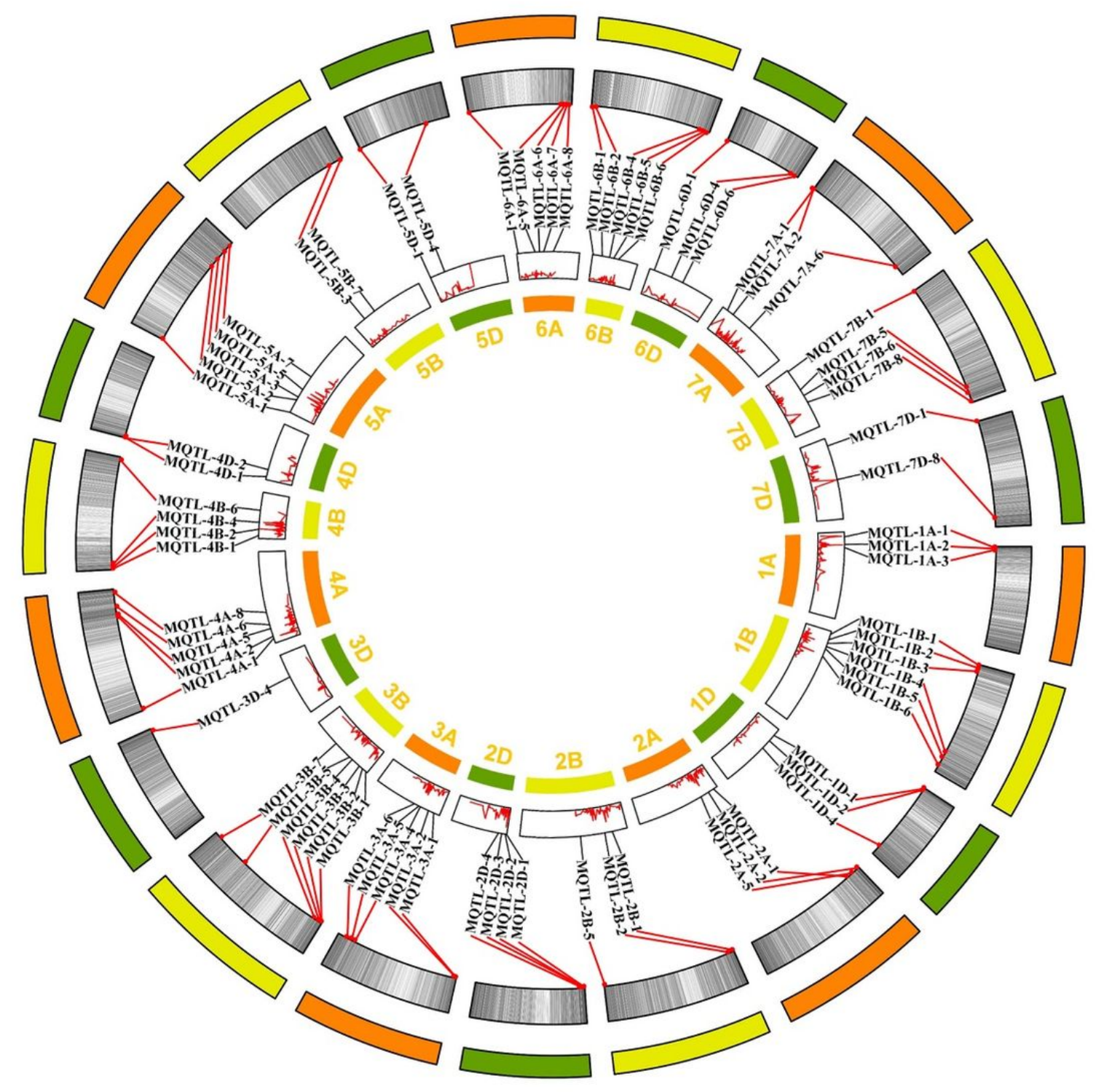

Figure 5

The chromosome distribution of the core MQTLs for yield and yield-related traits by integration of Meta-QTL and GWAS. The circles from inside to outside represent the genetic map, R2 values of initial QTLs, the distribution of high confidence genes and the physical map, respectively. 


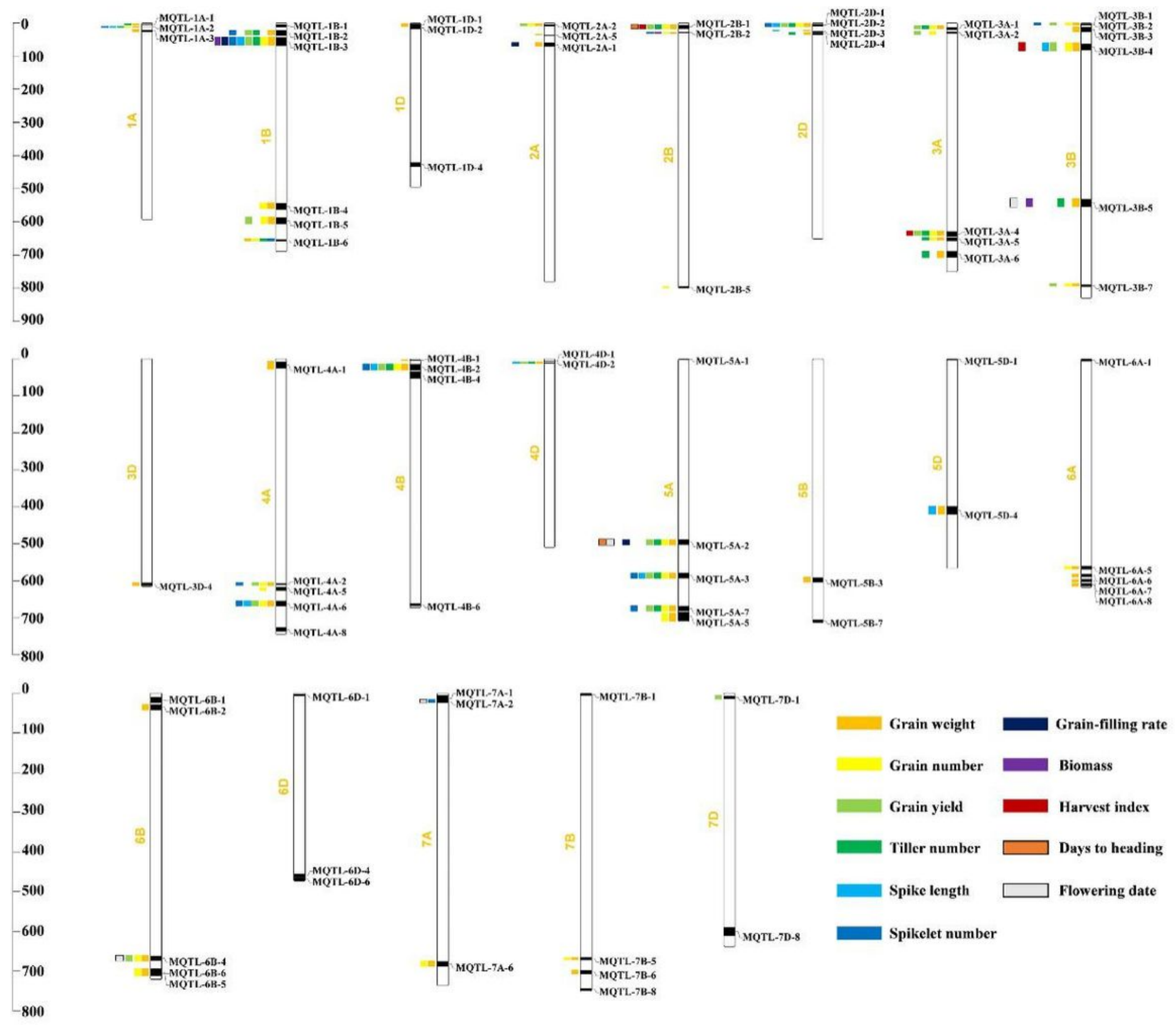

\section{Figure 6}

Distribution of 76 core MQTLs on chromosomes affecting multiple traits. Different yield-related traits are marked with different colored squares. The axis on the left represents the physical distance (MB). 


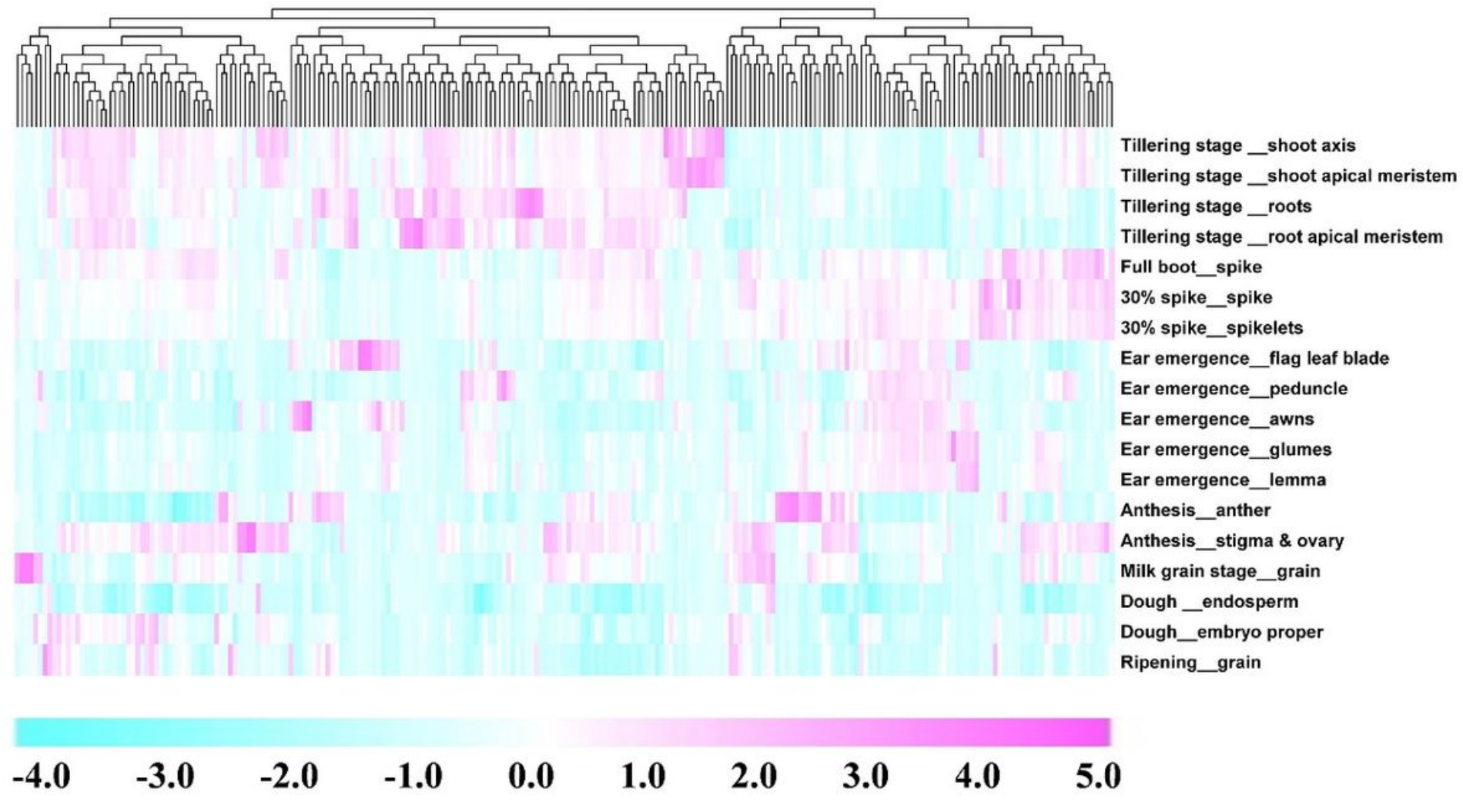

Figure 7

Expression characteristics of 237 candidate genes in 18 tissues. All transcriptome data was downloaded from expVIP (http://www.wheat-expression.com), and Log2 (TPM + 1) value was used to characterize the expression level. From sky blue to pink, the expression level increases from low to high. The detailed IDs of the candidate genes are shown in Fig. S1.

$\mathbf{a}$
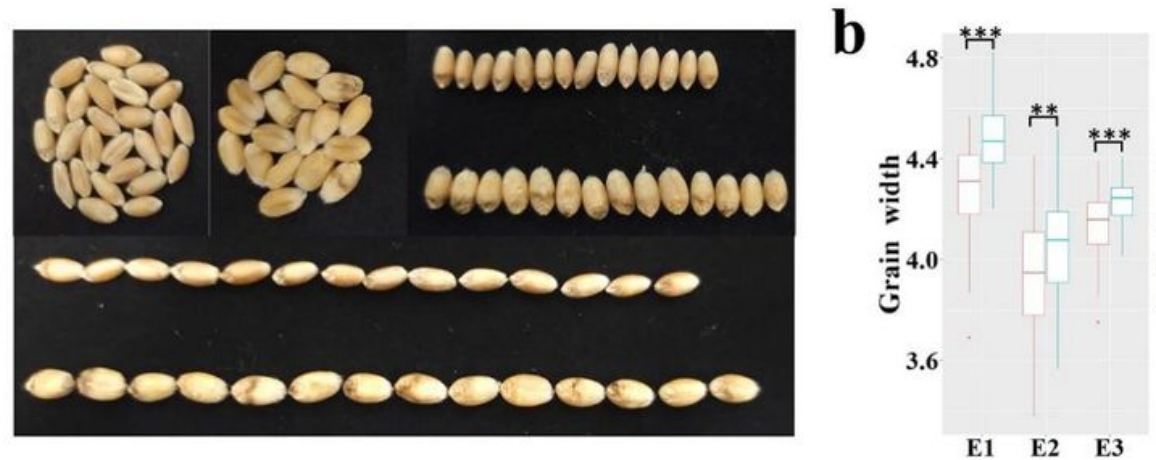
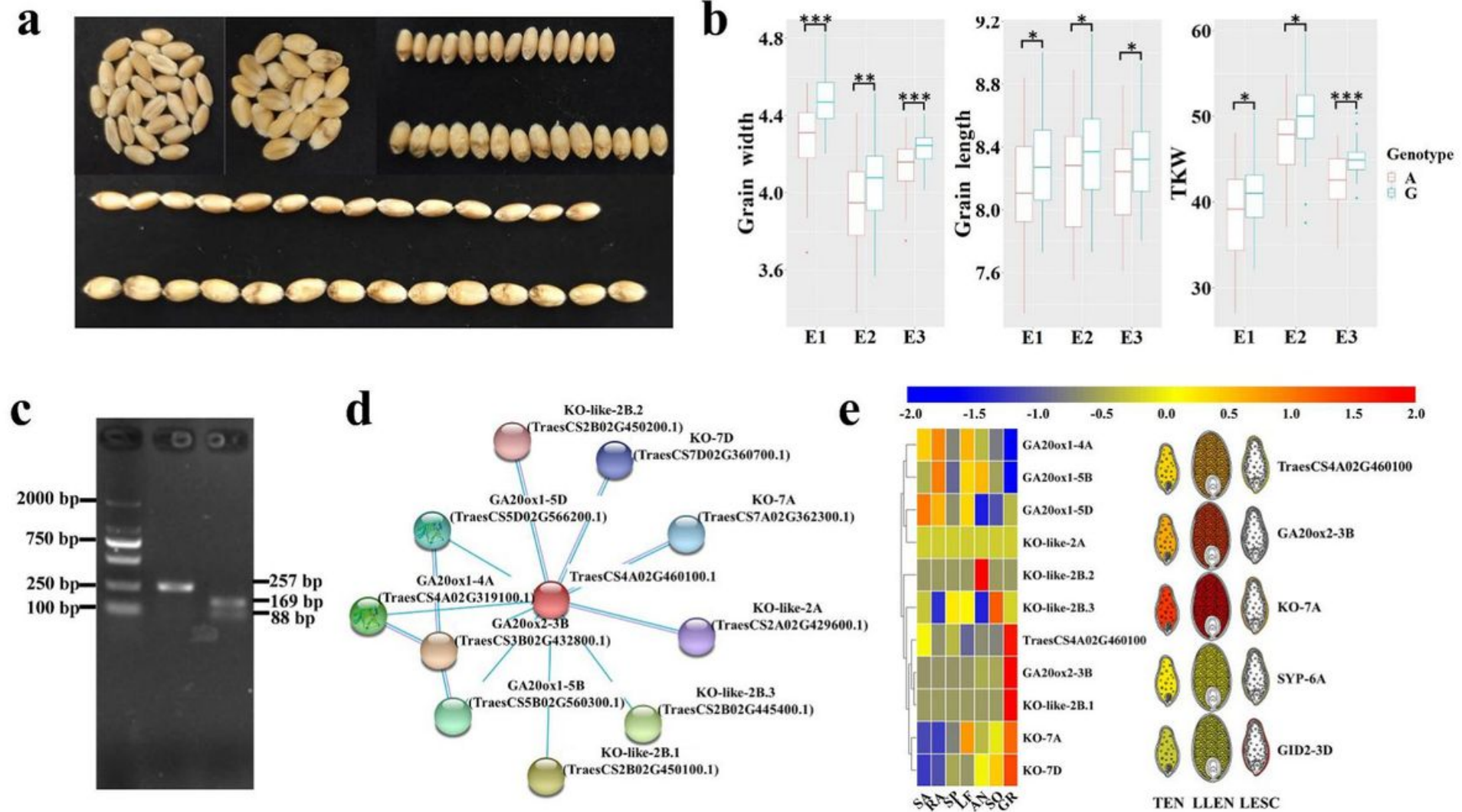
Functional verification of a novel candidate gene (TraesCS4A02G460100) in MQTL-4A-8 affecting grain size and grain weight (a) Grain morphology of wheat accessions with different haplotypes. From left to right are 'Lassit' (Hap 1-A) and 'Luomai 21' (Hap 2$G)$, respectively. (b) The differences in grain width and thousand grain weight between the two haplotypes of 94 wheat accessions. E1, E2 and E3 represent the three environments of 2016-2017, 2017-2018 and 2018-2019, respectively. ${ }^{*}, * *$ and *** represent the significant levels of $P<0.05, P<0.01$ and $P<0.001$, respectively. (c) The genotyping results of wheat accessions 'Lassit' and 'Luomai 21' using a CAPS marker for TraesCS4A02G460100. (d) The protein-protein interaction of TraesCS4A02G460100 predicted by STRING. (e) The tissue expression patterns of TraesCS4A02G460100 and its interacting genes. Wheat tissue expression data were downloaded from the wheat expression database (http://www.wheat-expression.com), and the heat map was displayed using log2 (TPM + 1). SA: shoot apical meristem, RA: root apical meristem, SP: spike, LF: leaf, AN: anther, SO: stigma \& ovary, GR: grain, EN: endosperm, EM: embryo proper. The expression data of separate tissues in developing grains were obtained from Xiang et al. (2019). TEN: transition stage endosperm (7 day after flowering), LESC: leaf early stage seed coat (10 day after flowering), LLEN: leaf late stage endosperm (20 day after flowering).

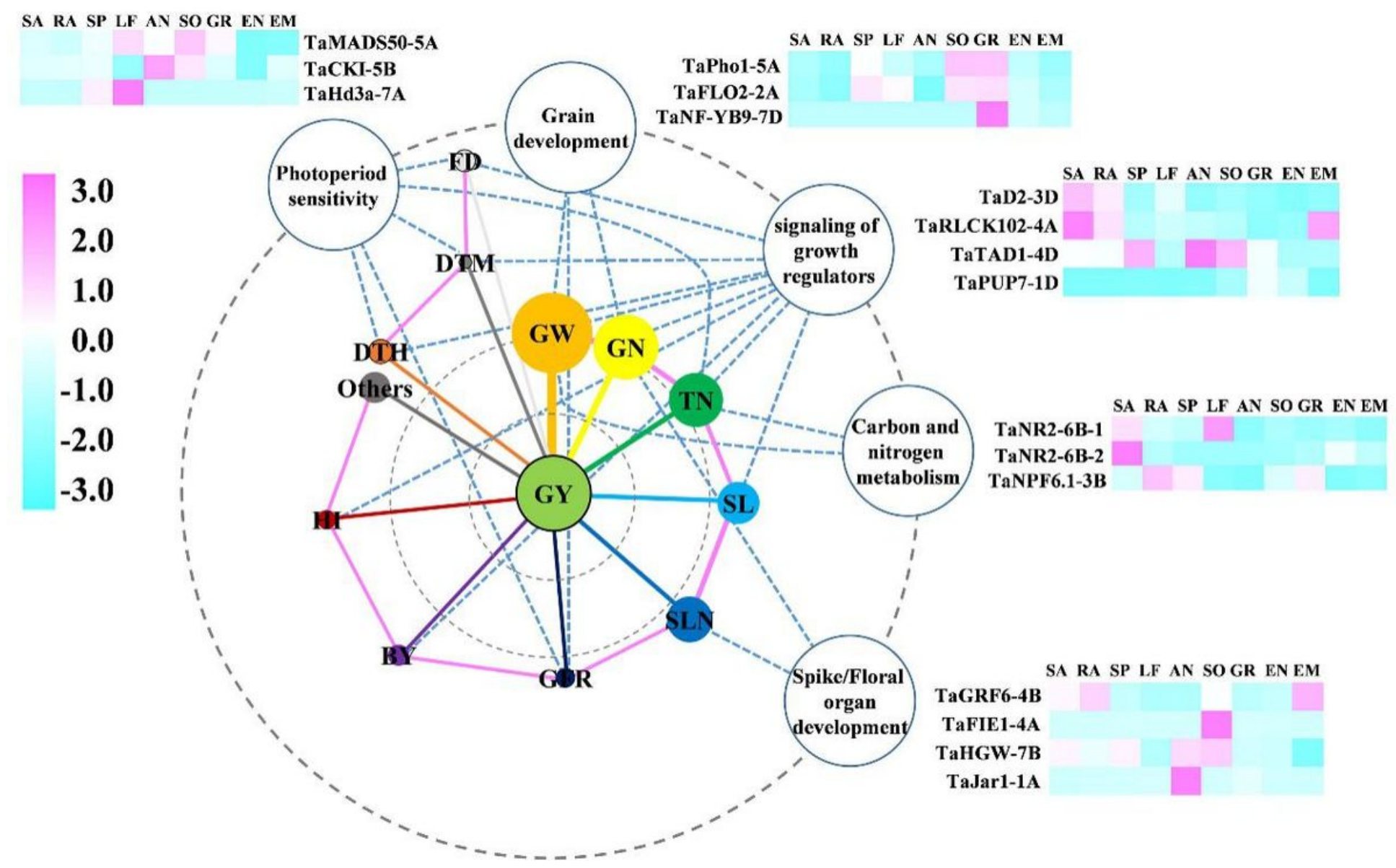

Figure 9

Contributions of yield-related traits to yield and possible factors affecting these traits. The inner circle represents the contributions of the 11 yield-related traits used in this study to yield. The size of each character circle represents the number of MQTL identified. The line length represents the number of MQTL co-located for each two traits and the shorter the line, the more MQTLs co-located with the two traits. The line thickness represents the number of initial QTLs contained in MQTLs and the thicker the line, the more QTLs the MQTL contains. The outer ring represents the main pathway or process affecting these yieldrelated traits. Several representative candidate genes within the MQTL regions and their tissue expression characteristics are marked near to each pathway. Wheat tissue expression data were downloaded from the wheat expression database (http://www.wheat-expression.com), and the heat map was displayed using log2 (TPM + 1). SA: shoot apical meristem, RA: root apical meristem, SP: spike, LF: leaf, AN: anther, SO: stigma \& ovary, GR: grain, EN: endosperm, EM: embryo proper. The wheat 
candidate genes are named according to their orthologous genes in rice. TaD2-3D: TraesCS3D02G106100, TaRLCK102-4A:

TraesCS4A02G016800, TaTAD1-4D: TraesCS4D02G341200, TaPUP7-1D: TraesCS1D02G393900, TaMADS50-5A:

TraesCS5A02G515500, TaCKI-5B: TraesCS5B02G433300, TaHd3a-7A: TraesCS7A02G115400, TaPho1-5A:

TraesCS5A02G395200, TaFLO2-2A: TraesCS2A02G517100, TaNF-YB9-7D: TraesCS7D02G216600, TaNR2-6B-1:

TraesCS6B02G024900, TaNR2-6B-2: TraesCS6A02G326200, TaNPF6.1-3B: TraesCS3B02G095900, TaGRF6-4B:

TraesCS4B02G060000, TaFIE1-4A: TraesCS4A02G388400, TaHGW-7B: TraesCS7B02G018300, TaJar1-1A:

TraesCS1A02G425100.

\section{Supplementary Files}

This is a list of supplementary files associated with this preprint. Click to download.

- Fig.S1.pdf

- SupplementaryTablerevised.xlsx 